\title{
Food security effects of multinational brands crop protection products: Evidence from cotton-wheat zone Punjab, Pakistan
}

\author{
Dissertation \\ to obtain the $\mathrm{Ph}$. $\mathrm{D}$. degree \\ in the International Ph. D. Programme for Agricultural Sciences in Göttingen (IPAG) \\ at the Faculty of Agricultural Sciences, \\ Georg-August-University Göttingen, Germany
}

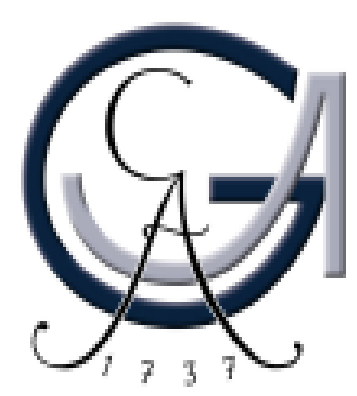

presented by

Muhammad Bilal

born in Faisalabad, Pakistan

Göttingen, December 2019 
1. Name of supervisor: Prof. Dr. Jan Barkmann

2. Name of co-supervisor: Prof. Dr. Bernhard Brümmer

3. Name of co-supervisor: Prof. Dr. Meike Wollni

Date of dissertation: $12^{\text {th }}$ December 2019 


\section{Summary}

Throughout the past years, agricultural technological inputs have been actively evolving with a moderate rate of technology adoption. The adoption of agricultural technological inputs has been encouraged by, among others, escalating demand in the food sector in both developed and developing countries. While the adoption of agricultural technological inputs has been becoming important in developing countries, rigorous assessment of the quality and origin of available technologies and their outcomes in developing countries is lacking.

Firstly, there are is an abundance and prevalence of generic, nationally produced agricultural products in contrast to multinational brands agricultural products in the agricultural mainland of Pakistan. The widespread adoption of generic agricultural products has serious consequences on sustainable agricultural development. Among the available agricultural technological products, particularly, crop protection products (for example insecticides, fungicides, herbicides, and chemicals for seed treatment) have an obvious impact on the biophysical environment. Secondly, the multinational brands crop protection products outclass generic crop protection products due to their rigorous process of product development and product quality assurance. However, the multinational brands crop protection products are often much more expensive. Thus, the adoption of multinational brands crop protection products versus generic crop protection products among smallholder farming households may have important consequences on sustainable agricultural development for developing countries. While some implications of such adoption decisions have been intensively research, some other highly relevant research aspects were not covered.

First, with regard to factors affecting adoption of crop protection products, empirical evidence shows that smallholder farming households in Pakistan, in general, adopt crop protection products. It is known that socioeconomic variables determine adoption of recommended crop protection products practices and the quantity of crop protection products applied. While farm and farmer capital influence initial adoption of crop protection products, the determinants of the adoption of more expensive crop protection products promising a higher quality remains unaddressed. Second, there is a growing body of literature on the outcomes of adoption decisions regarding agricultural technologies. The empirical evidence shows that technology adoption may contribute positively to productivity, poverty alleviation, and food security in developing countries. However, the following points have not been addressed: 
(i) food security effects of multinational brands crop protection products in the agricultural mainland of developing countries;

(ii) farm harvest effects of multiple crop protection product categories instead of only one category (pesticides, fungicides, herbicides, insecticides, and chemical seed treatment);

(iii) self-selection biased and potential heterogeneity of multinational brands crop protection products and adopters countenance.

Hence, this dissertation aims to fill respective gaps in the existing literature in two core areas. Firstly, we aim to analyse the association of farm and farmer capital variables with the adoption of improved crop protection products. Compared to generic, nationally produced products, we expect multinational brands crop protection products to promise (and deliver) an improved overall product quality. Secondly, we want to test if the adoption of multinational brands crop protection products improves food security. Both areas use data from a cross-sectional survey conducted in 2017. The survey includes data from 275 smallholder farming households from the cotton-wheat zone in the Punjab province, Pakistan. The Punjab is the agricultural heartland of Pakistan.

First, we employ ordered probit models to estimate the role of farm and farmer capital towards the adoption of multinational brands crop protection products in the Punjab, Pakistan. The results show that agricultural extension services, among others, farm and farmer capital variables are fundamental to technology adoption. The adoption of multinational brands crop protection products is strongly positively correlated to household food security. The cross-sectional survey exclusively contains non-experimental observations. Therefore, this evidence of correlation between the adoption of multinational brands crop protection products and farmers food security may be tainted due to possible self-selection bias and potentially existing, unobserved sources of heterogeneity. This situation represents a substantial methodological challenge.

Second, we address this methodological challenge of relying in non-experimental observations by using an endogenous switching probit model to account for potential heterogeneity in estimating adoption effects on food security. Full information maximum likelihood estimates indicate that adoption of multinational brands crop protection products is guided by comparative advantage: farmers adopt multinational brands crop protection products if they benefit from adoption compared to non-adoption. Furthermore, we find statistically significant evidence of heterogeneity effects. These effects are significantly higher for those farmers who adopted relative to those who 
did not adopt. On top of that, the result of selection modelling, yet again, decisively supports the hypothesis that the accessibility of agricultural extension information via radio is the easiest way to disseminate proven agricultural technologies and to foster the adoption of multinational brands crop protection products.

A few salient take away and policy implications can be drawn from this dissertation. From a fundamental science point of view, these results provide, for the first time, evidence that adoption of multinational brands crop protection products is principally guided by the same farm and farmer capital variables as initial adoption. This result confirms that the intensification of agricultural extension service visits and the promotion of agricultural extension information via radio broadcasts stand out as most promising policy options. Additionally, we determine the fundamental role of multinational brands crop protection products for enhancing food security of smallholder farming households. Particularly, we observed that the adoption of multinational brands crop protection products may reduce food security of non-adopters if they adopt. So, promoting the adoption of multinational brands crop protection products without carefully considering likely net benefits for individual farming households would be misguided. 


\section{Acknowledgments}

What a constructive journey it was, which has turned my vision into a new horizon of research. A vision which goes beyond materialistic pursuits and we do the effort for the betterment of humanity. To me, nothing could have been better than Göttingen to achieve this milestone.

Lucky I am that I covered this journey with beautiful and novel companions. Foremost, I have to mention my supervisor Prof. Dr. Jan Barkmann for his continuous support, moral and scholarly guidance throughout this journey. I am truly indebted and learnt a lot from our discussions about the rationality of smallholders. These have also casted a profound impact on my understandings about scientific writings, qualitative survey research, and nevertheless, on my personal development.

Countless thanks to Prof. Dr. Bernhard Brümmer. What a gem he is to work with. His visionary suggestions will remain thought provoking for me and essentially enabled my understandings about the core issues of the subject. Special thanks to Prof. Dr. Meike Wollni for being an active and constructive part of my supervisory committee.

It is really hard to mention only few names among the big bunch of my friends/colleagues/staff circle. They wish me strength and luck to achieve this milestone. And my dear friends/colleagues/staff if you are reading this acknowledgment then you better know, I write about you.

Feel proud and emotional now. I need heavenly words to describe the unprecedented efforts of my mother and father that bring me from cradle to this cadre. I want to pay special gratitude for my brothers and sisters for their continuous support in this entire journey. Special, smart, and sweet thanks to my wife, my sons and my daughter.

Finally, I feel honour with saying thanks to Higher Education Commission (HEC) of Pakistan for their uninterrupted financial support (Ref: PM/OSSII/BatchVI/Germany/2015/80517) to bring this journey to a successful end. The financial support received from the Foundation fiat panis (Project no: 29/2017) is very gratefully acknowledged. This research has also been supported by the continuous consultation support of German Academic Exchange Service (DAAD). 


\section{Table of Contents}

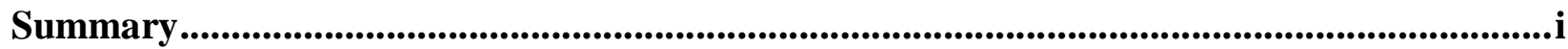

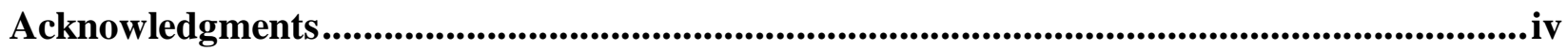

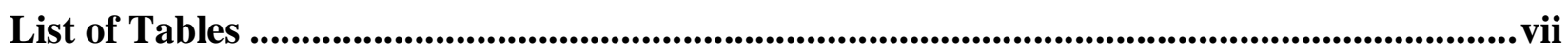

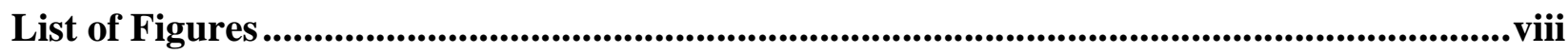

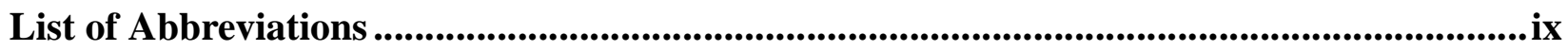

1 Salient features of the agriculture sector in Pakistan...................................................1

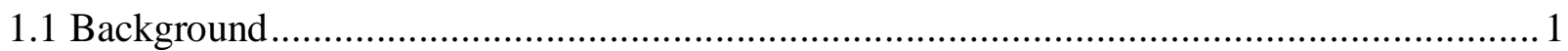

1.2 Overview of crop protection products and cotton crop in Pakistan.............................. 2

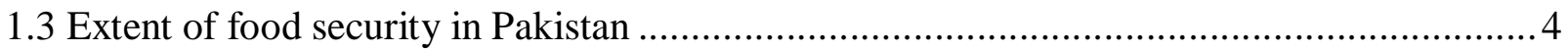

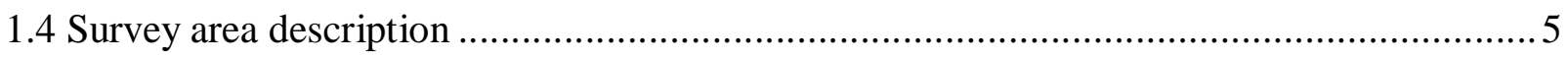

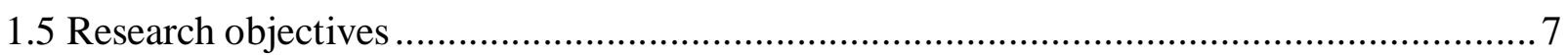

1.5.1 Farm and farmer capital foster adoption of improved quality agrochemical inputs in the cotton-wheat zone of the Punjab, Pakistan .................................................................. 7

1.5.2 Multinational brands versus generic crop protection products: Does the choice matter for the food security of cotton-wheat farmers in Pakistan? ............................................ 8

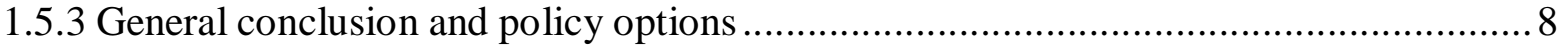

2 Farm and farmer capital foster adoption of improved quality agro-chemical inputs in the cotton-wheat zone of the Punjab, Pakistan............................................................................. 10

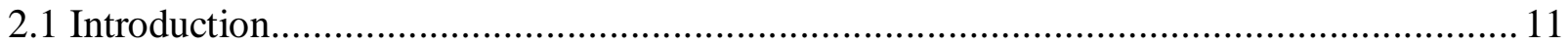

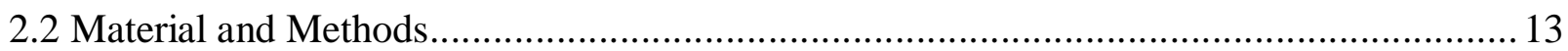

2.2.1 Study area and Pakistan smallholder agriculture............................................. 13

2.2.2 Pakistani agrochemical inputs market ........................................................... 13

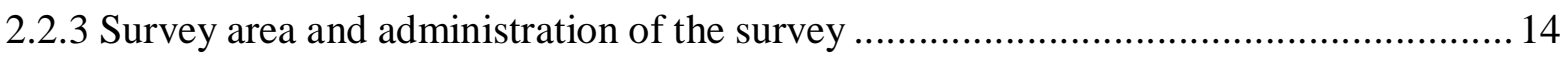

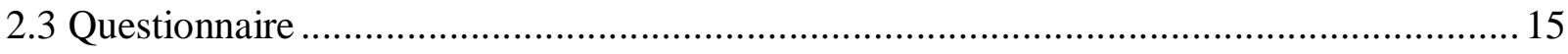

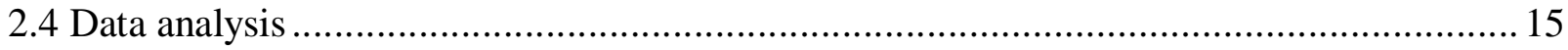

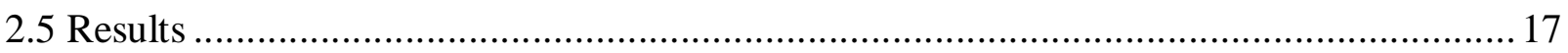

2.5.1 Smallholder farming households' proportions with respect to input types ................. 17

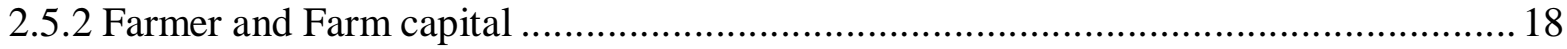

2.5.3 Determinants adoption: ordered probit model ........................................... 20

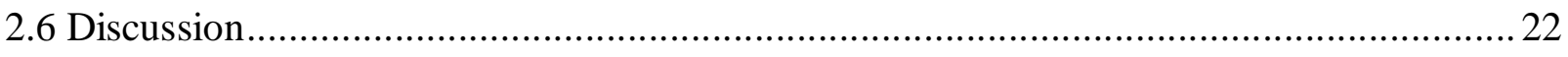

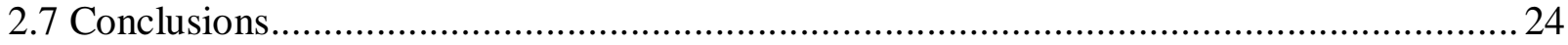


3 Multinational brands versus generic crop protection products: Does the choice matter for the food security of cotton-wheat farmers in Pakistan? .................................................25

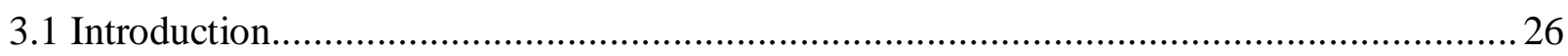

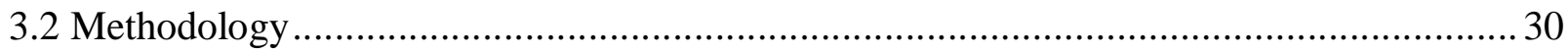

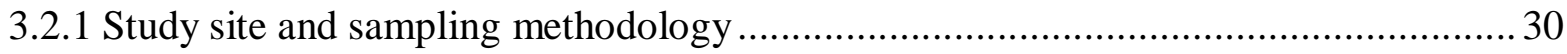

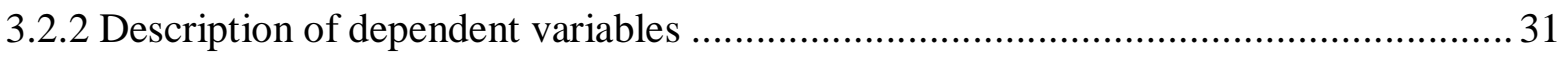

3.2.3 The Household Food Insecurity Access Scale (HFIAS) ....................................... 32

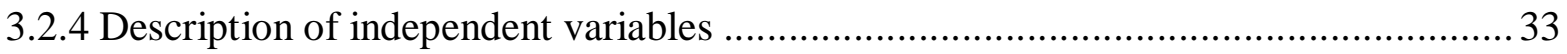

3.2.5 Conceptual and methodological framework .............................................. 35

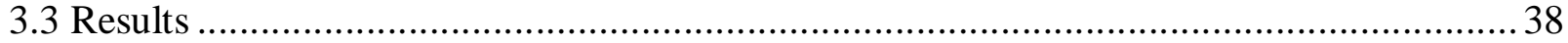

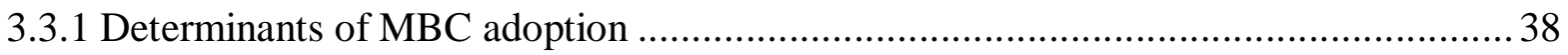

3.3.2 Estimates of the endogenous switching probit model: treatment effects....................39

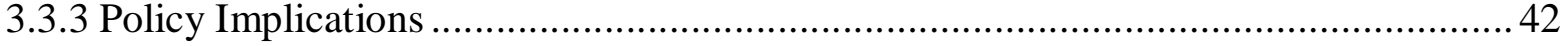

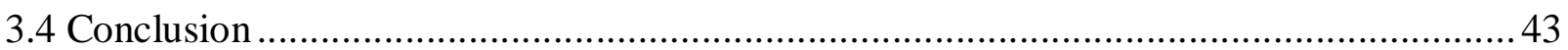

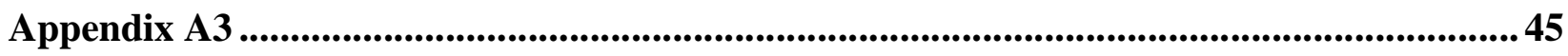

4 General conclusion and policy options...................................................................51

4.1 Background and conceptual framework ....................................................... 51

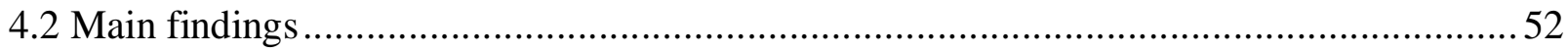

4.3 Implications for farming households and potential policy options .............................54

4.4 Limitations and future research prospects and endeavors .....................................55

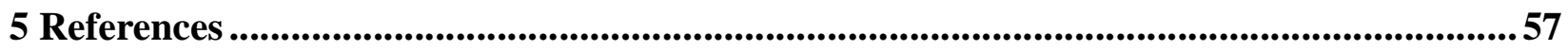

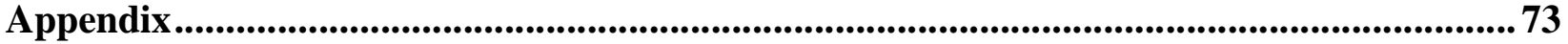

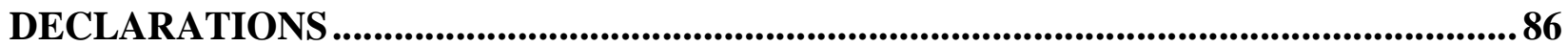




\section{List of Tables}

Table 1.1. Import volume of insecticides and export volume of wheat, raw cotton, and cotton yarn in million US\$

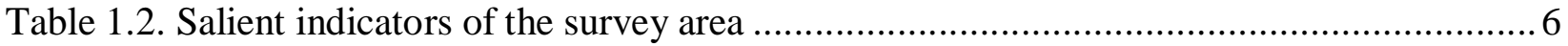

Table 2.1. Farmer's opinion about the quality of adopted agrochemical inputs types................... 16

Table 2.2. Use of agrochemical input types A (improved quality), B (national level quality), and C (base quality) by surveyed smallholder farming households...................................................... 17

Table 2.3. Smallholder farming households' distribution with respect to inputs types ................. 17

Table 2.4. Descriptive summary of farm capital and farmer capital (FFC) variables $(N=275) \ldots .18$

Table 2.5. Regression estimates of agrochemical inputs categories from an ordered probit model

Table 3.1. Adoption and food security status of sampled households ....................................... 32

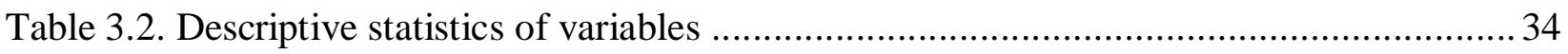

Table 3.3. Estimates of the endogenous switching probit model................................................. 39

Table 3.4. Treatment effects of MBC adoption on food security status......................................... 41

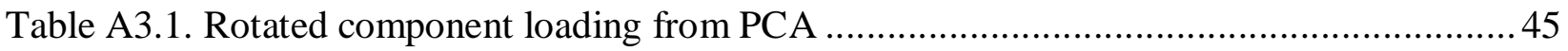

Table A3.2. Correlation of selection instruments with adoption and food security status.............45

Table A3.3. The relevance and exogeneity conditions for selection instruments......................... 45

Table A3.4. Falsification approach to validate selection instrument ...........................................46

Table A3.5. Regression estimates of adoption of MBC from a probit model (main model) ........ 46

Table A3.6. Estimates of the endogenous switching probit model (second model) ….................. 47

Table A3.7. Treatment effects of MBC adoption on food security status (second model) ............48

Table A3.8. Regression estimates of adoption of MBC from a probit model (second model) ..... 48

Table A3.9. Treatment effects of MBC adoption on food security status (reduced model excluding all potentially endogenous variables)

Table A3.10. Estimates of the endogenous switching probit model (reduced model excluding all potentially endogenous variables)

Table A3. 11. Treatment effects of exclusive MBC adoption versus exclusive GC adoption on food security status $(N=222)$. .50 


\section{List of Figures}

Figure 1. 1. Percentage share of total farms with respect to size of landholding in Pakistan (The

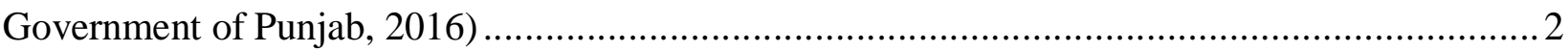

Figure 1. 2. Percentage share of total farms with respect to size of landholding in Punjab (The

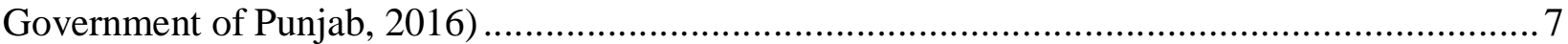

Figure 2. 1. Agro-ecological zone of the Punjab, Pakistan (source: Ahmad et al., 2016)............. 15 Figure 2. 2. (a)/(b)/(c)/(d): $95 \%$ confidence interval plots of farm capital variables with respect to

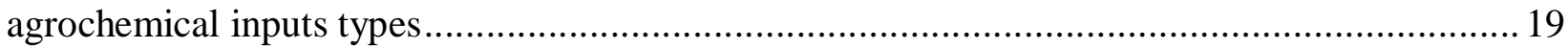

Figure 2. 3. (a)/(b)/(c)/(d): $95 \%$ confidence interval plots of farmers' capital variables with respect

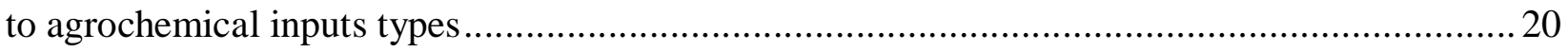

Figure 3. 1. Spatial locations of surveyed villages in three randomly selected subdistricts (tehsils) of Punjab 


\section{List of Abbreviations}

$\begin{array}{ll}\text { ACQ } & \text { Agro-chemicals input Quality } \\ \text { ANOVA } & \text { Analysis of Variance } \\ \text { BH } & \text { Base Heterogeneity } \\ \text { Bt } & \text { Bacillus thuringiensis } \\ \text { FANTA } & \text { Food and Nutrition Technical Assistance } \\ \text { FAO } & \text { Food and Agriculture Organization } \\ \text { FFC } & \text { Farm and Farmers Capital } \\ \text { FIML } & \text { Full Information Maximum Likelihood } \\ \text { GC } & \text { Generic Crop protection products } \\ \text { GDP } & \text { Gross Domestic Product } \\ \text { GFSI } & \text { Global Food Security Index } \\ \text { GHI } & \text { Global Hunger Index } \\ \text { GM } & \text { Genetically Modified } \\ \text { HFIAS } & \text { Household Food Insecurity Access Scale } \\ \text { HFSSM } & \text { Household Food Security Survey Module } \\ \text { MBC } & \text { Multinational Brands Crop protection products } \\ \text { NID } & \text { Normally and Independently Distributed } \\ \text { OECD } & \text { Organization for Economic Cooperation and Development } \\ \text { TH } & \text { Transitional Heterogeneity } \\ \text { TT } & \text { Treatment effect on the Treated } \\ \text { TU } & \text { Treatment effect on the Untreated } \\ \text { UNDP } & \text { United Nations Development Programme } \\ \text { USD } & \text { United States Dollar } \\ \text { USDA } & \text { United States Department of Agriculture } \\ & \end{array}$




\section{BabaGe(A.S) keDua}




\section{Salient features of the agriculture sector in Pakistan}

\subsection{Background}

Still being the vital single sector, as agriculture contributes almost $19 \%$ in the GDP, unfortunately, the share of the said sector in the country's GDP has been declining over the decades. Currently, it contributes almost $19 \%$ in the country's GDP in contrast to $25 \%$ for the year 2000. Likewise, the share of the said sector in employment to the country's labour force is following the same pattern. In the year 2000, this single sector absorbed $44 \%$ of the national labour force while currently absorption has declined to 39\% (The Government of Pakistan, 2000-2019a). Mainly, the stagnant productivity of cash crops and staple food crops (for example cotton, maize, rice, sugarcane, and wheat) contributes to the decline of agricultural GDP (Rehman et al., 2015; Azam and Shafique, 2017; Rehman et al., 2019). Furthermore, the transition towards farm mechanisation especially in large agricultural farms, is additionally reduces the agricultural labour (Rehman, 2012).

There are three categories of agricultural farms in Pakistan according to size. The farms with area less than 5 acres [ 2.02 ha] constitute the small farms; the farms with an area more than 5 acres [ 2.02 ha] but less than 25 acres [ 10.11 ha] constitute the medium farms, and the large farms are categorized as 25 acres [ 10.11 ha] or more. According to the Punjab Bureau of Statistics, $65 \%$ of agricultural farms are small farms and farmers operating these farms are considered as smallholder farming households, $31 \%$ of agricultural farms comprised in the category of medium farms and operated by medium farmers. The medium and small farms in Pakistan account for $96 \%$ of all farms, the remaining 4\% are large farms (see Fig. 1.1) (The Government of Punjab, 2016).

Smallholder farming households in Pakistan are in the majority. However, this majority comes along with pertinent snags and underpinnings. The use of substandard/low quality crop protection products (for example insecticides, fungicides, herbicides, and chemicals for seed treatment), lack of education, lack of extension contacts, water scarcity and inadequate distribution of water, low off-farm income and less off-farm income opportunities, and lack of farm inputs are the pertinent snags of smallholder farming households (Alene and Manyong, 2007; Jaghdani et al., 2012; Bashir and Schilizzia, 2013; Ali et al., 2014; Hashmi, 2016; Hänke and Barkmann, 2017).

While they are constrained to lack of farm inputs at the same time, they are exposed to inferior and substandard inputs. Farm inputs, especially the application of crop protection products during pest 
control has overall relevance for agricultural sustainability (Tilman et al., 2002; Sharifzadeh et al., 2018) and with the productive potential of the farms (Oerke, 2006; Alam et al., 2016). On top of that, the lack of availability and accessibility of crop protection products may offset their agronomic benefits (Jalal-ud-din, 2011).

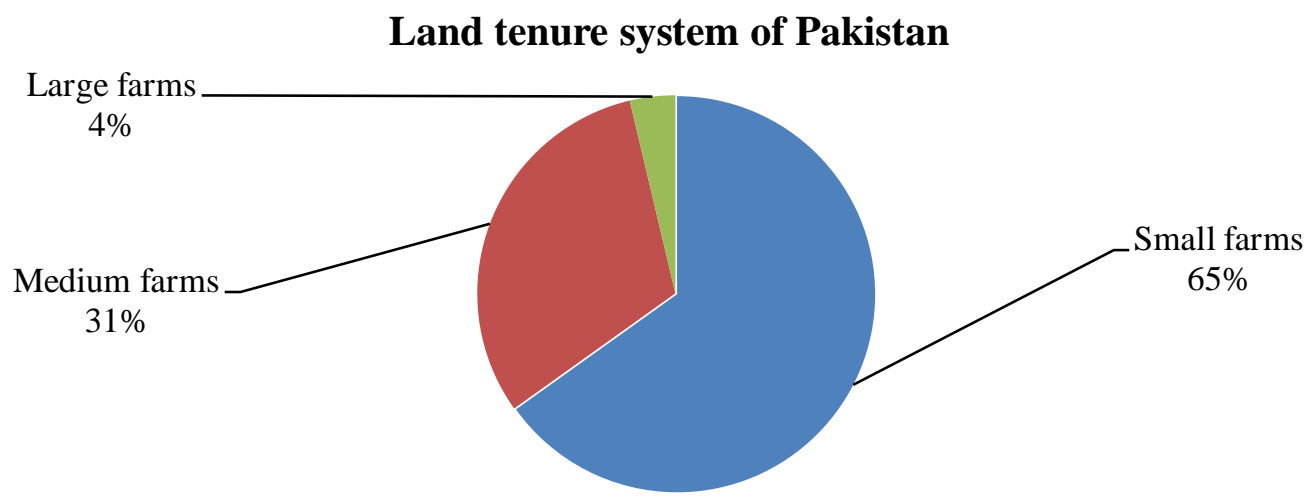

Figure 1. 1. Percentage share of total farms with respect to size of landholding in Pakistan (The Government of Punjab, 2016)

The overall agriculture sector statistics are thought-provoking, and knowing the fact the government of Pakistan initiated "Prime Minister's Agriculture Emergency Programme". The main aim is to enhance the productivity of important crops and the reorganization of extension service at all level (The Government of Pakistan, 2019a). The quality of agricultural products, particularly, the quality of crop protection products is not explicitly vivid as an integral part of this emergency programme. The brief scenario of crop protection products in Pakistan is described below in section 1.2 .

\subsection{Overview of crop protection products and cotton crop in Pakistan}

Pakistan is the signatory of relevant conventions for crop protection products - for example Rotterdam convention on prior informed consent procedure for certain hazardous chemicals and pesticides since 1999 and Stockholm convention on persistent organic pollutant since 2001 - based on the manifesto to discourage the adoption of crop protection products which shows the positive association with severe health issues and environmental degradation (Rotterdam convention, 2019; Stockholm convention, 2019). 
According to neoclassical theory, farmers will adopt crop protection products if it gives the positive discounted net present value of stream of returns from its adoption (Wilson and Tisdell, 2001). However, this may favour the adoption of unsustainable pest control strategies, particularly, in developing countries (Aga, 2019). The use of substandard/low quality crop protection products retards agricultural development, and thus induces low productivity (Hashmi, 2016). It also comes along with severe detrimental factors, particularly, on farmers' health (Antle and Pingali 1994; Khooharo et al., 2008) and farm habitat (Khan et al., 2002). Yet the empirical research evidence shows the adoption of and/or prevalence of substandard/low quality crop protection products in the agricultural heartland of Pakistan (Khan et al., 2011; Khan et al., 2013). Therefore, the role of the government institutions is very important in the quality assurance of agricultural inputs (Ali and Sharif, 2012; Saqib and Tachibana, 2014; Baloch and Thapa, 2016). Moreover, according to diffusion of innovation theory (Rogers, 1983), the adoption of improved technology and its efficient utilization goes along with the role of institutions projection mainly the agricultural extension services (see for example Abbas et al., 2003; Aldosari et al., 2017).

In Pakistan, the Department of Plant Protection has established protocols for the registration of crop protection products. There are three different types of registration protocols to be fulfilled based on the origin, field trials, and on the sample analysis of given crop protection products. First, the type A crop protection products registration protocols are based on the country of its origin. The department grants import permission to agricultural crop protection products if they have their origin from a country listed in OECD and China. Second, type B registration protocols based on the efficacy trials of particular agricultural crop protection products and their demonstration in the field trials before their final inception and allocating the trade name. Third, Type $\mathrm{C}$ registration protocols involve only the sample analysis and there are no field trials before their marketing permission (The Government of Pakistan, 2018a).

The crop protection products sector of Pakistan is import-dependent and over the time it witnesses an increased in the import volume (see Table 1.1). Pakistan imports multinational brands crop protection products $(\mathrm{MBC})$ from OECD (Organization for Economic Cooperation and Development) countries and from China to meet the domestic demand. However, the demand is also met by generic crop protection products (GC). The GC includes low-quality formulations, unpredictably variable concentration of active agents, insufficient declarations, safety, and usage 
information in contrast to MBC (Khan et al., 2013; Hashmi, 2016). At the same time, the higher price of MBC tempted smallholder farming households to adopt generically formulated crop protection products (Khooharo et al., 2008). However, the adoption of branded products shows an attraction for consumer due to products information, products specification, and packaging attributes (Lewis et al., 2016). Table 1.1 presents the import volume of the crop protection products and export of raw cotton, cotton yarn, and wheat for the last five years. It is evident from Table 1.1 that import volume of insecticides increases on an average while the export share of wheat and cotton in the country's agricultural GDP faces decline.

Table 1.1. Import volume of insecticides and export volume of wheat, raw cotton, and cotton yarn in million US\$

\begin{tabular}{lcccc}
\hline Year & Import of insecticides & Export of wheat & Export of raw cotton & Export of cotton yarn \\
\hline $2017-18$ & 119 & 60 & 56 & 988 \\
$2016-17$ & 97 & $-*$ & $-*$ & 844 \\
$2015-16$ & 116 & $-*$ & $-*$ & 989 \\
$2014-15$ & 100 & $-*$ & $-*$ & 1464 \\
$2013-14$ & 96 & 7 & 196 & 1716 \\
\hline
\end{tabular}

Notes: -* means during those particular fiscal years no exports earning for the said items.

Data source: (Pakistan Economic Survey, 2013-14; 2014-15; 2015-16; 2016-17; 2017-18)

Cotton is the life line of Pakistan's economy and contributes $0.8 \%$ in the country's GDP. Mainly, due to pests' attack (for example whitefly, pink bollworm) the production of cotton has declined by 18 percent (The Government of Pakistan, 2019b). Most importantly, the initial adoption of crop protection products has been increasing swiftly since the adoption of Bt (Bacillus thuringiensis) cotton in the year 2002 (Nazli et al., 2010; Spielman and Kouser, 2018). Because, Bt cotton fails to resist against detrimental sucking pests (for example whitefly, mealybug, aphids, and jassids) and consequently, farmers increase the use of the crop protection products (Abdullah, 2010; Report, 2015; Spielman et al., 2017).

\subsection{Extent of food security in Pakistan}

Pakistan has a population of approximately 208 million and only half of its population food secures (The Government of Pakistan, 2019a). According to the 1996 World Food Summit defines food security as; an individual has at all times, access and availability of sufficient, safe, and healthy food to maintain a healthy active life (FAO, 2017). A very recent comprehensive report by Ministry of National Food Security and Research, Pakistan, highlights statistics of food insecurity domains. 
It proclaims that $18 \%$ of the country's population is undernourished and $45 \%$ suffered with high level of severe stunting, $15 \%$ wasting, and almost 30\% are underweight. On top of that, $46 \%$ of rural population is suffering from the malnourishment problems (The Government of Pakistan, 2018b).

This research focuses on the determinants of adoption of MBC by smallholder farming households; the food security effects of the adoption of MBC in the cotton-wheat zone of the Punjab province, Pakistan. We assess the food security outcomes by the Household Food Insecurity Access Scale (HFIAS). HFIAS consists of nine-questions, which captures the households' level of access to food (Coates et al., 2007). HFIAS is widely used in several countries including developing countries of Africa and Asia (Chinnakali et al., 2014; Gebreyesus et al., 2015). We considered HFIAS, due to its applicability across cultures, economical, require less data, and technically appropriate (Kabunga et al., 2014). We have selected cotton-wheat zone of the Punjab province, Pakistan. This selection is also supported by the Pakistani official documentation and empirical research evidences of the prevalence and the accessibility of MBC versus GC in the survey area (see section 1.2). Section 1.4 describes the survey area and section 1.5 describes the research objectives with the specific title of the research papers.

\subsection{Survey area description}

Pakistan is located in the subtropics region and has diverse topography. It hosts several world's highest mountains and glaciers to the few world's hottest spots (Mohenjo-daro and district Sibi $53.5^{\circ} \mathrm{C}$ ) and deserts (Thar and Cholistan). Pakistan is confederation of four provinces. Punjab contributes a major share of cash and staple food crops to meet the domestic demand because of the bounty of cultivated area and its canal irrigation system. Of the total irrigated area of $\sim 14.88$ million ha, $79 \%$ is irrigated by the canal irrigation system and the rest by tube wells and other sources (Pakistan Bureau of Statistics, 2019).

There are nine divisions (division is the highest administrative unit) in the Punjab province. Among these, Bahawalpur, Multan, and Sahiwal divisions constitute the cotton-wheat zone of Pakistan. Each division based on administration is further delineated into districts, tehsils (below district administrative unit), and union councils (lowest administrative unit with a formal government and comprises several villages). Using a multi-stage random sample, households from 18 villages in the cotton-wheat zone of Punjab province were surveyed from September to December 2017. The 
final sample size yields $\mathrm{N}=275$ smallholders who were selected for face to face interview. Before final survey, we did a pilot survey ${ }^{1}$ in January 2017 and interviewed a small size $(N=45)$ of smallholders from Punjab, Pakistan. That helped in the subsequent improvements of the survey instrument and in the knowing of the basics of survey area (for example cropping pattern, agroecological zones, substantive farming community, and on top of that, extent of availability and accessibility of different types of crop protection products in the survey area). Table 1.2 presents the percentage shares of important farming indicators of the survey area from the total of province.

Table 1.2. Salient indicators of the survey area

\begin{tabular}{lccccc}
\hline Indicators & $\begin{array}{c}\text { Bahawalpur } \\
\text { Division }\end{array}$ & $\begin{array}{c}\text { Multan } \\
\text { Division }\end{array}$ & $\begin{array}{c}\text { Sahiwal } \\
\text { Division }\end{array}$ & Punjab & $\begin{array}{c}\text { \% share of } \\
\text { survey area }\end{array}$ \\
\hline Total reported area (thousands ha) & 2,155 & 1,523 & 1,030 & 17,680 & 27 \\
Area sowed under cotton (thousands ha) & 738 & 744 & 152 & 2,322 & 70 \\
Area sowed under wheat (thousands ha) & 991 & 872 & 511 & 6,980 & 34 \\
Total tube well (numbers) & 103,919 & 60,392 & 71,876 & $1,028,424$ & 23 \\
Total tractors (numbers) & 51,554 & 43,027 & 32,729 & 331,905 & 38 \\
Total threshers (numbers) & 21,458 & 17,684 & 15,670 & 140,133 & 39 \\
Harvesters/Reapers (numbers) & 9,298 & 3,386 & 1,743 & 31,609 & 46 \\
Population (numbers) & $11,464,031$ & $12,265,161$ & $7,380,386$ & $110,012,442$ & 28 \\
Literacy of rural areas (ratio) & 0.26 & 0.30 & 0.39 & 0.38 & \\
Literacy of urban areas (ratio) & 0.57 & 0.61 & 0.66 & 0.65 & \\
\hline Data source: (Punjob Development Statistics, & $2016 ;$ Pakistan Burea of Statistics, 2017-18) & & \\
\hline
\end{tabular}

Data source: (Punjab Development Statistics, 2016; Pakistan Bureau of Statistics, 2017-18)

It is evident from Table 1.2 that a substantial share of area under cotton crop (70\%) constitutes the survey area of this research. Also, it presents a considerable percentage of the total population of the province. However, the literacy ratio of the rural urban face of the survey area is substantially low and similarly for Punjab.

Figure 1.2 shows percentage shares of total farms with respect to size of landholding in Punjab. On the top of the agricultural farms' segmentation, it comprises $64 \%$ small farms; the agricultural farms comprised in the category of medium farms are 34\%. The medium and small farms in Punjab account for $98 \%$ of all farms and remaining $2 \%$ are large farms (The Government of Punjab, 2016).

\footnotetext{
${ }^{1}$ A discussion paper based on pilot survey data is online available at: https://ideas.repec.org/p/zbw/daredp/1708.html
} 


\section{Land tenure system of the Punjab}

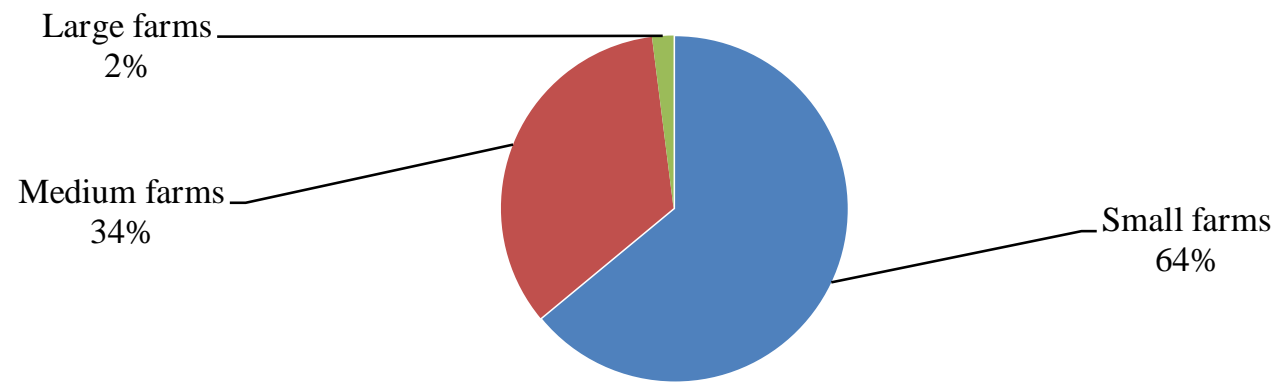

Figure 1. 2. Percentage share of total farms with respect to size of landholding in Punjab (The Government of Punjab, 2016)

\subsection{Research objectives}

The continuing part of this dissertation is arranged in the following manner. In chapter 2 we explore that how farm and farmer capital foster adoption of improved quality agrochemical inputs ${ }^{2}$ (multinational brands crop protection products) in the cotton-wheat zone of the Punjab, Pakistan. Chapter 3 covers the food security effects of MBC with evidence from cotton-wheat zone Pakistan. Chapter 4 is about the general conclusion (take away) in which we summarize the key findings of this dissertation. It is focusing on future guidelines for agricultural administration in Pakistan, in nutshell the policy options perspective. It ends with scope and hope for future research prospects and endeavours.

\subsubsection{Farm and farmer capital foster adoption of improved quality agrochemical inputs in the cotton-} wheat zone of the Punjab, Pakistan

This paper investigates the role of farm and farmer capital towards the adoption of improved quality agrochemical inputs (multinational brands crop protection products). The paper covers the existing knowledge and research gap about the initial adoption of agrochemical inputs in developing countries of Asia and Africa. We find convincing evidence about research gap regarding the adoption of improved quality agrochemical inputs. We use ordered probit models to estimate the role of farm and farmer capital towards the adoption of improved quality agrochemical inputs in

\footnotetext{
2 The chapter has been accepted for publication in Journal of Agriculture and Rural Development in Tropics and Subtropics: https://doi.org/10.17170/kobra-20191217881. The chapter is co-authored by Jan Barkmann. The accepted chapter uses the same title "Farm and farmer capital foster adoption of improved quality agro-chemical inputs in the cotton-wheat zone of the Punjab, Pakistan". Therefore, for better understanding we let "improved quality agrochemical inputs" unchanged in this chapter, basically it translates as "multinational brands crop protection products".
} 
the Punjab, Pakistan. The results show the agricultural extension services are fundamental in the disseminations of current technology to the farming community. Due to the fact that this is a variable under rather direct and government controls that can be improved at moderate cost, we suggest that Pakistani and Punjabi agricultural administrations focus on improvements here.

1.5.2 Multinational brands versus generic crop protection products: Does the choice matter for the food security of cotton-wheat farmers in Pakistan?

This paper investigates the food security effects of MBC adoption. The paper covers the adoption of existing technology towards farm harvest, food security, and poverty in developing countries. We find convincing evidence about the research gap regarding the adoption of $\mathrm{MBC}$ and its consequences on food security status of the farming community in developing countries. We use HFIAS to elicit food security status. The paper addresses the methodological challenges of nonexperimental studies; the potential self-selection bias and potential heterogeneity due to nonrandom distributions of respondents into treatment (adopters = exclusive MBC) versus control (non-adopters = GC/otherwise) groups. Therefore, we use an endogenous switching probit model to estimate the effect of treatment on food security status. The full information maximum likelihood estimates illustrate that adoption of $\mathrm{MBC}$ is guided by comparative advantage. We find statistically significant evidence of transitional heterogeneity; the heterogeneity effects are significantly higher for those smallholder farming households that adopted relative to those that did not adopt. We assess the role of multinational brands crop protection products for enhancing the food security status of smallholder farming households. For policy options, we see listening of agricultural extension information via radio by the smallholder farming households in the limelight, among others, key determinants of exclusive MBC adoption (for example farm distance from the farm of village head, farm distance from the main road, off-farm income sources, ownership of farm machinery, and seasonal labour). The intensification of agricultural extension information via radio stands out as a most promising policy option for the adoption multinational proven agricultural technologies. For the future research prospects, we suggest investigating further reasons why nonadopter's smallholder farming households are unable to improve their food security status if they will exclusively adopt MBC.

\subsubsection{General conclusion and policy options}

Few take-away and policy options for the agricultural administration of Pakistan and the developing countries, in general, can be drawn from chapter 2 and chapter 3 of this dissertation. 
From a fundamental science point of view, our results provide, for the first time, evidence that adoption of $\mathrm{MBC}$ is influenced principally by the same farm and farmer capital variables as initial adoption of crop protection products. We conclude the fundamental role of $\mathrm{MBC}$ for enhancing the food security status of smallholder farming households. We also witness that the MBC adoption may cut the food security status of non-adopters if they adopt. Furthermore, our results confirm that the intensification of agricultural extension service visits, among others, key variables stand out as a most promising policy option. These take-away, further suggestions for policy options, and the limitations of this study are briefly discussed in chapter 4 of this dissertation. 


\title{
2 Farm and farmer capital foster adoption of improved quality agro- chemical inputs in the cotton-wheat zone of the Punjab, Pakistan
}

\begin{abstract}
Adoption of yield-enhancing agricultural inputs fosters agricultural intensification in low-income countries. In Pakistan, initial adoption of agrochemicals is already widespread; the low quality of much of the inputs contributes to severe health, environmental and enduring pest problems, however. While the positive influence of farm capital and farmer capital on initial adoption is well documented, the adoption of improved quality inputs is little researched. We reduce the knowledge gap investigating smallholder adoption of improved quality agrochemical inputs in the Punjab, Pakistan. Using multi-stage random sampling, a pre-tested and piloted farming household survey was administered to smallholder farming households from 18 villages across three districts of the cotton-wheat zone $(N=275)$. Ordered probit models show that several farming and farm capital variables (cotton crop area, farm machinery, no-tillage farming, adoption in the neighbourhood) as well as several farmer capital variables (age, education, off-farm income, agricultural extension services, source of agricultural credit) influence adoption of improved quality agrochemical inputs. Of these variables, an intensification of agricultural extension service visits appears as the most promising policy option. From a fundamental science point of view, our results provide, for the first time, evidence that adoption of improved quality agrochemical inputs is influenced principally by the same variables as initial adoption.
\end{abstract}

Keywords: adoption of agricultural innovations, agrochemical inputs, smallholder farming households, sustainable intensification

\footnotetext{
The chapter has been accepted for publication in Journal of Agriculture and Rural Development in Tropics and Subtropics: https://doi.org/10.17170/kobra-20191217881. This chapter is co-authored by Jan Barkmann (JB). The contribution of each is as follows: Muhammad Bilal (MB) and JB conceptualized the design of the research. MB carried out survey and collected data with the assistance of two local data collectors. MB analysed data and interpreted. JB assisted by adding constructive comments and important feedbacks at various stages of the research and drafting.

Acknowledgements: The authors thank two data collectors and also the unconditional participation of respondents. We gratefully thank financial support by Foundation fiat panis (project no: 29/2017) and also by HEC/DAAD scholarship (reference: 91591599). The important suggestions for the improvement of the initial version of this chapter by Prof. Dr. Bernhard Brümmer and for the final version of this paper by three anonymous reviewers are cordially acknowledged.
} 


\subsection{Introduction}

Adoption of yield-enhancing agricultural inputs is a central component of agricultural development through closing frequently existing yield gaps (e.g., Mueller et al., 2012). There is a persisting yield gap among low-income countries of Asia such as Pakistan and India (wheat yield: 2.97 and 3.22 $\mathrm{Mg} \mathrm{ha}^{-1}$ ) compared to, e.g., Germany and the United Kingdom (7.64 and 8.28 $\mathrm{Mg} \mathrm{ha}^{-1}$; FAO, 2019). With high rates of population growth in Pakistan (2.4\% $\mathrm{a}^{-1}$, The Government of Pakistan, 2019a) leading to escalating demands for staple food, the adoption of yield-enhancing agricultural inputs appears to be without alternative (Hossain et al., 2006; Khan and Shah, 2011; Salazar et al., 2015; Manlosa et al., 2019). Among these inputs are agrochemicals whose use is positively associated with yield (Pretty and Bharucha, 2014; Koondhar et al., 2018). Adoption of improved quality inputs can be a decisive factor for further sustainable intensification if initial adoption of - low-quality inputs is already wide-spread but low productivity persists (Khooharo et al., 2008; Hashmi, 2016).

The adoption of low-quality agrochemical inputs comes along with substantial health and environmental risks. Pesticide exposure may reduce the health of, in particular, the rural poor including the female population resulting in income losses and fatalities (Khan et al., 2002; London et al., 2002; Mrema et al., 2017). Aggressive and inappropriate use of agrochemicals is also responsible for water pollution (Azizullah, 2011) and can endanger ecosystem services from soil microorganisms, fish, birds, and other non-targeted organisms (Aktar et al., 2016). In contrast, using improved quality agrochemical inputs may reduce negative health effects (Abedullah et al., 2015) and environmental risks (Kouser and Qaim, 2014).

The initial adoption of yield-enhancing inputs has consistently been shown to be positively associated with farm and farmer capital (FFC) variables such as age, education, land, labour, farm mechanisation, as well as use of improved varieties, and fertilisers (Harper et al., 1990; Doss and Morris, 2001; Iqbal et al., 2002; Ali and Sharif, 2012; Tijani and Nurudeen, 2012b; Hailu et al., 2014; Lambert et al., 2015; Koondhar et al., 2018). Likewise, physical availability of inputs and attributes such as market access and distance to extension service are often positively associated with adoption (Lee, 2005; Mwangi and Kariuki, 2015; Simtowe et al., 2016).

In contrast, the adoption of improved quality agrochemical inputs is little researched. Exceptions include a few studies on the association of socio-economic variables with the adoption of 
recommended agrochemical practices and extent of pesticide use (Tijani and Nurudeen, 2012a; Issa et al., 2016). In sum, these studies indicate that farmers experience, farmers education, and pesticides price are significantly associated with the extent of given pesticides usage and also with the recommended agrochemical practices. These studies are limited, inter alia, by (i) addressing only one broad category of agrochemicals (pesticides vs. fungicides, herbicides, insecticides, and chemical seed treatment), and (ii) by their focus on recommended practices. Still, they support the hypotheses that the adoption of improved quality agrochemical inputs is positively associated with the same FFC variables as initial adoption.

Initial adoption of low-quality inputs is prevalent in Pakistan where low-quality agrochemicals retard agricultural development (Khan et al., 2013; Hashmi, 2016) as pest problems remain a top of issue impending agricultural development (Oerke, 2006; Khan et al., 2012; Dhaliwal et al., 2015). Likewise, grave environmental (Nafees et al., 2008) and health concerns (Tijani and Nurudeen, 2012b) plague Pakistani agriculture. Thus, investigating the adoption of improved quality agrochemical inputs (fungicides, herbicides, insecticides, and chemical seed treatment) in the agricultural heartland of Pakistan serves two purposes: improving the regional and national knowledgebase for closing the yield gap in Pakistan, The Royal Society, 2009; Garnett et al., 2012; USDA, 2016).

Therefore, we use the cross-sectional data collected in 2017 from 275 smallholder farming households of cotton-wheat zone from the Punjab province, Pakistan. We are mainly interested in addressing the following research questions: Do FFC variables of smallholder farming households affect the adoption of improved quality agrochemical inputs?

This paper is part of a more comprehensive study that also investigates the impact of the adoption of improved quality inputs on food security. Respective analyses, in fact, indicate that adoption is not only positively correlated to food security; they also indicate that substantial positive effects of adoption can be documented even if endogeneity effects are considered (Bilal et al., in prep.; Bilal and Barkmann, 2018). 
The paper is structured as follows. In section 2, we characterise the study area, the agrochemicals market in Pakistan, and the sampled smallholder farming households. Furthermore, the section describes sampling strategy and data analysis. Section 3 provides the results, which are discussed in section 4, focusing on some institutional implications, in particular for the agricultural administration in Pakistan. Section 5 concludes with some policy implications.

\subsection{Material and Methods}

\subsubsection{Study area and Pakistan smallholder agriculture}

In Pakistan, $58 \%$ of farms are categorised as "small farms" (national definition: area $\leq 5$ acres [ 2.02 ha]; The Government of Punjab, 2010). The smallholders operating these farms use less advanced technological inputs due to socio-economic constraints (Thapa and Gaiha, 2011). Smallholder production systems, among others, tend to lack access to water, authorised and/or improved quality seeds, easy access to input and output markets and to agricultural credit; in contrast, use of adulterated and inferior quality of agrochemical inputs are widespread (Khan et al., 2013; Bilal et al., 2015). This is a serious issue as the potential yield loss due to weeds in cotton may vary from $33-50 \%$ and from $24-40 \%$ in wheat (Oad et al., 2007; Ali et al., 2013). The potential yield loss due to pests in cotton may vary from $29-40 \%$ and from $35-40 \%$ in wheat (Khan et al., 2012; Rehman et al., 2015).

\subsubsection{Pakistani agrochemical inputs market}

In Pakistani agrochemical inputs market recently available agrochemicals on the basis of specific formulation consists of 108 insecticides, 39 herbicides, and 30 fungicides with glyphosate being the most common active ingredient in herbicides in Pakistan (Khan et al., 2010; Hameed et al., 2017). Farm productivity-enhancing inputs including agrochemical inputs and fertilisers worth $\sim 735$ million USD (United States Dollar) were imported to fulfil the domestic needs during the fiscal year 2017-2018. The agrochemical inputs market import share in Pakistan is estimated to be worth 120 million USD during the fiscal year 2017-2018 (The Government of Pakistan, 2019b). The proportions of agrochemicals input types in the Pakistani agrochemicals market in recent past are as follows: insecticides $42 \%$, herbicides $23 \%$, fungicides $10 \%$, granules $16 \%$, and crop supplement 9\%. Among the major crops of Pakistan, most agrochemical inputs by the value are 
mainly used for cotton and wheat (47\%/160 million USD; 18\%/60 million USD (Pakistan Crop Protection Associate, 2016).

We differentiated between three tiers ('types') of agrochemical input quality following the Department of Plant Protection of the Pakistani national Ministry of National Food Security and Research. We designated these types A to C (The Government of Pakistan, 2018a):

- type A (improved quality) inputs are legally imported based upon their successful registration in an OECD (Organization for Economic Cooperation and Development) listed country or in China.

- type B (intermediate quality) inputs receive a marketing permission based on efficacy trials and field experiments prior to registration. The field trials are conducted over two crop seasons before allocating the trade name.

- type C (base quality) receive a marketing permission without any field trials only based on a sample analysis.

\subsubsection{Survey area and administration of the survey}

Pakistan is the confederation of four provinces. Punjab province is the largest with respect to population size (53\%) and the total net area under arable agriculture (69\%) (Pakistan Bureau of Statistics, 2019). There are nine divisions in Punjab province (division is the highest administrative unit). Of these, three divisions (Bahawalpur, Multan, and Sahiwal division) constitute the cottonwheat zone of Pakistan. Using a multi-stage random sample, households from 18 villages in the cotton-wheat zone of Punjab province (Fig. 2.1) were surveyed from September to December 2017.

At the first stage, one district ${ }^{3}$ (Pakpattan, Rahim Yar Khan, Vehari) was selected from each division with type $\mathrm{A}$ to $\mathrm{C}$ inputs being widely available using a population proportional random selection, and one tehsil ${ }^{4}$ (Burewala, Pakpattan ${ }^{5}$, Sadiqabad) was randomly selected from each district. In a second stage, five to six union councils ${ }^{6}$ were randomly selected from each tehsil (total of 17 union councils). In the third stage, a selection of one to two villages from each union council resulted in a total of 18 villages. In the last stage, we randomly selected 11-20 smallholder farms

\footnotetext{
${ }^{3}$ District is the subsequent administrative unit with a formal government after division in context to Pakistan.

${ }^{4}$ Tehsil is below district administrative unit.

5 Pakpattan is a district and consists of two tehsils; one of its tehsil bears the same name "Pakpattan".

6 Union council is the lowest administrative unit with a formal government.
} 
from each village. Thus, the final sample size yields $N=275$ smallholders who were interviewed in person by the first author and two advanced student assistants.

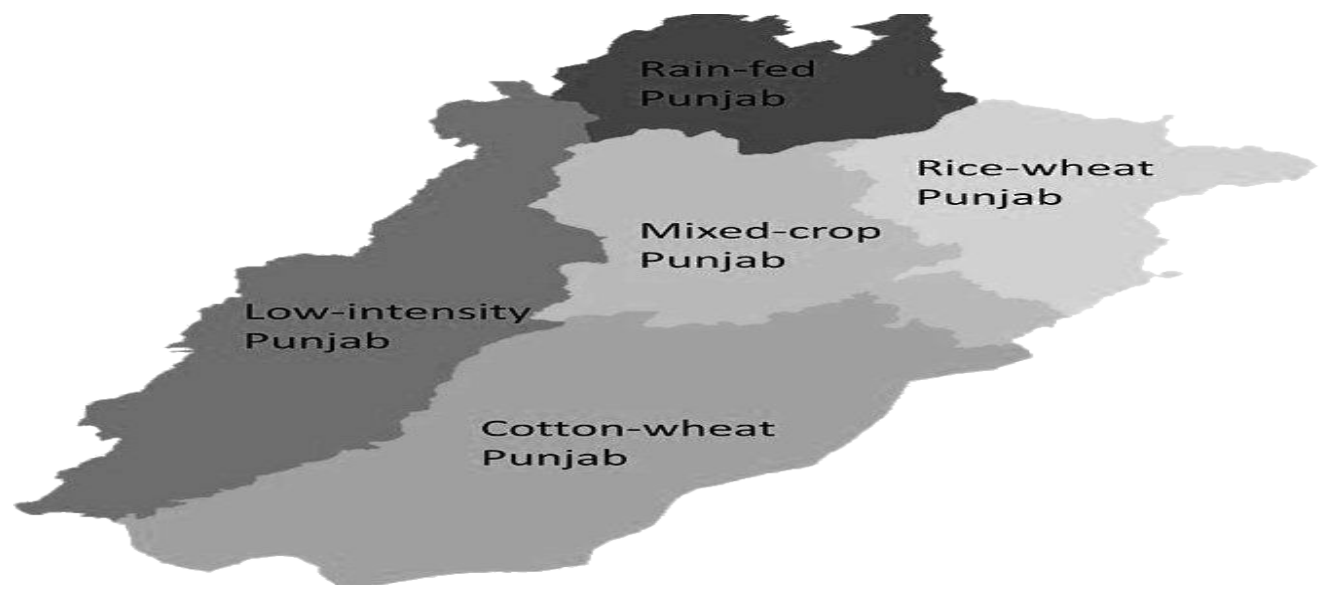

Figure 2. 1. Agro-ecological zone of the Punjab, Pakistan (source: Ahmad et al., 2016)

\subsection{Questionnaire}

In January 2017, a preliminary version of the questionnaire was piloted in the research area $(\mathrm{N}=45)$, and subsequently improved. The final questionnaire included sections on FFC variables, beliefs of respondents on the quality of agrochemical inputs available in local markets, perceptions on the importance of dosage, time of spraying, and recommended instructions for spraying. The questionnaire was originally designed in English, and translated to Urdu by the first author. A copy of the questionnaire is available from the first author upon request.

\subsection{Data analysis}

To determine influences on input adoption, we used discrete response models with more than two responses. As the input types have a natural quality order, we employed ordered probit models (Verbeke and Ward, 2006). To further rationalize the ordering of the agrochemical's quality, we showed and asked all smallholder farming households about their opinion/knowledge about typical examples of products belonging to the three quality tiers (see introduction). The subjective quality assessment of the farmers about qualitative aspects of agrochemicals being practised at their farms and their knowledge/opinion about other available agrochemicals which in principle not being practised at their farms, closely matched the quality ordering used in this study (see Table 2.1). In particular, the most (83\%) of exclusive users of agrochemicals input type A assessed it as improved 
quality, to the contrary, only a minuscule percentage (14\%) of exclusive users of agrochemicals input type $\mathrm{C}$ assessed it as improved quality.

Table 2.1. Farmer's opinion about the quality of adopted agrochemical inputs types

\begin{tabular}{lllll}
\hline Response & $\begin{array}{l}\text { Full sample } \\
(N=275)\end{array}$ & $\begin{array}{l}\text { Type A users } \\
(N=171)\end{array}$ & $\begin{array}{l}\text { Type B users } \\
(N=37)\end{array}$ & $\begin{array}{l}\text { Type C users } \\
(N=103)\end{array}$ \\
\hline Improved quality & $51 \%$ & $83 \%$ & $42 \%$ & $14 \%$ \\
Low quality & $23 \%$ & $17 \%$ & $50 \%$ & $62 \%$ \\
Poor quality & $26 \%$ & $0 \%$ & $8 \%$ & $24 \%$ \\
Total & $100 \%$ & $100 \%$ & $100 \%$ & $100 \%$ \\
\hline
\end{tabular}

Since ordered probit coefficients lack an immediately meaningful interpretation, we report marginal effects for each explanatory variable. Using type A, type intermediate (due to highly infrequent proportion of mix use options of adoption of agrochemical inputs in the total sample, we integrated all mix users and termed them as intermediate users (see Table 2.3), and type $\mathrm{C}$ as responses, each response had a minimum of 50 data points (cf. Sudman, 1976; see Table 2.2). Several farm capital and farmer capital variables for which literature suggested an influence (see introduction), were used as independent variables (see Table 2.4). In detail, our ordered response model assumed the following form (Wooldridge, 2010).

$$
\mathrm{y}_{\mathrm{i}}^{*}=\mathrm{x}_{\mathrm{i}}^{\prime} \beta+\varepsilon_{\mathrm{i}}, \quad \varepsilon_{\mathrm{i}} \sim \operatorname{NID}(0,1)
$$

$\mathrm{y}_{\mathrm{i}}^{*}=$ unobserved or latent variable

$\mathrm{y}_{\mathrm{i}}=$ observed variable not in the equation

$\mathrm{y}_{\mathrm{i}}=0$ if $\mathrm{y}_{\mathrm{i}}^{*} \leq \gamma_{1}$,

$\mathrm{y}_{\mathrm{i}}=1$ if $\gamma_{1}<\mathrm{y}_{\mathrm{i}}^{*} \leq \gamma_{2}$

$\mathrm{y}_{\mathrm{i}}=2$ if $\gamma_{2}<\mathrm{y}_{\mathrm{i}}^{*}$,

Where $x_{i}^{\prime}$ is set of explanatory variables and $\beta$ are the estimated parameters for the corresponding explanatory variables, the stochastic disturbance term $\varepsilon_{\mathrm{i}}$ is assumed to be normally and independently distributed $(0,1)$. Here $\gamma$ is an unknown cut point (or threshold parameter, if y takes three adoption responses, then there will be two cut points, $\gamma_{1}$ and $\gamma_{2}$ ). Therefore, $\gamma$ is jointly estimated with $\beta$. Consequently, the ordered probit model for three agrochemical inputs types is given as under:

$$
\mathrm{ACQ}_{\mathrm{ij}}=\alpha+\beta \mathrm{X}_{\mathrm{i}}+\delta \mathrm{Z}_{\mathrm{i}}+\varepsilon_{\mathrm{i}} \quad \varepsilon_{\mathrm{i}} \sim \mathrm{NID}(0,1)
$$


where ACQ is the adopted agrochemical inputs quality, subscript i represents a smallholder farming household, and $\mathrm{j}$ represents the agrochemical inputs category respondents adopted $(\mathrm{j}=0,1,2)$. In particular, $\mathrm{j}=0$ indicates that a household adopted agrochemical input $\mathrm{C}$ category, $\mathrm{j}=1$ whether or not a respondent adopts agrochemical input type intermediate category, and $\mathrm{j}=2$ whether or not a respondent adopts agrochemical input type A category (see section 3.1, Table 2.3); X and Z are the FFC variables thought to determine ACQ. $\alpha, \beta, \delta$, and $\varepsilon$ estimated using maximum likelihood procedures. We made a robust standard error calculation for an ordered probit model to address the heteroscedasticity (Greene, 2002). We employed Pregibon's link test for model specification (Pregibon, 1980), which basically implies that when we regress explanatory variables on the predictions squared; the null hypothesis is that predictions squared have no explanatory power. The data were analysed using STATA version 11.

\subsection{Results}

\subsubsection{Smallholder farming households' proportions with respect to input types}

Compared to exclusive users of input types A and C, exclusive users of type B as well as users of more than one type are relatively infrequent (Table 2.2). For subsequent analyses, we designated all respondents who did not exclusively use type A (52\%) or type C inputs (29\%) as users of an intermediate type (Table 2.3).

Table 2.2. Use of agrochemical input types A (improved quality), B (national level quality), and $\mathrm{C}$ (base quality) by surveyed smallholder farming households

\begin{tabular}{llllllll}
\hline District & $\begin{array}{l}\text { Input } \\
\text { Type A }\end{array}$ & $\begin{array}{l}\text { Input } \\
\text { Type A+B }\end{array}$ & $\begin{array}{l}\text { Input } \\
\text { Type A+C }\end{array}$ & $\begin{array}{l}\text { Input } \\
\text { Type B }\end{array}$ & $\begin{array}{l}\text { Input } \\
\text { Type B+C }\end{array}$ & $\begin{array}{l}\text { Input } \\
\text { Type C }\end{array}$ & Total \\
\hline District Pakpattan & 32 & 9 & 11 & 5 & 6 & 26 & 89 \\
District Rahim Yar Khan & 59 & 1 & 3 & 11 & 1 & 31 & 106 \\
District Vehari & 52 & 2 & 2 & 1 & 1 & 22 & 80 \\
Total & 143 & 12 & 16 & 17 & 8 & 79 & 275 \\
\hline
\end{tabular}

Table 2.3. Smallholder farming households' distribution with respect to inputs types

\begin{tabular}{llll}
\hline Agrochemical inputs type & Ordered & Frequency & Percent \\
Agrochemical inputs type A only & 2 & 143 & 52 \\
Agrochemical inputs type Intermediate & 1 & 53 & 19 \\
Agrochemical inputs type C only & 0 & 79 & 29 \\
Total & & 275 & 100 \\
\hline
\end{tabular}




\subsubsection{Farmer and Farm capital}

The descriptive summary of FFC variables of smallholder farming households is presented in Table 2.4. Most notably, less than a quarter of all farms own farm machinery (23\%), few have access to quality source of agricultural information (16\%) and even less have their own tube well for irrigation $(15 \%)$ or are members of a local farmer association $(10 \%)$.

Table 2.4. Descriptive summary of farm capital and farmer capital (FFC) variables $(N=275)$

\begin{tabular}{|c|c|c|c|c|}
\hline Definition of variables & Mean & SD & Min & Max \\
\hline \multicolumn{5}{|l|}{ Farm capital variables } \\
\hline Area in ha & 1.30 & 0.55 & 0.4 & 2.02 \\
\hline Area in ha (cotton) & 0.77 & 0.58 & 0 & 2.02 \\
\hline Farm machinery (yes=1; no=0) & 0.23 & 0.42 & 0 & 1 \\
\hline Farm distance to village head $(\mathrm{km})$ & 1.32 & 1.32 & 0 & 7 \\
\hline Tube well (own $=1$; otherwise $=0$ ) & 0.15 & 0.36 & 0 & 1 \\
\hline No-tillage (yes $=1 ;$ no=0) & 0.45 & 0.49 & 0 & 1 \\
\hline Neighbourhood adopters (numbers)* & 2.46 & 2.32 & 0 & 12 \\
\hline \multicolumn{5}{|l|}{ Farmers Capital variables } \\
\hline Age (years) & 43.53 & 12.92 & 17 & 73 \\
\hline Education in years & 5.70 & 4.41 & 0 & 16 \\
\hline Off-farm income (yes=1; no=0) & 0.45 & 0.49 & 0 & 1 \\
\hline Membership of local farmers union (yes $=1 ; \mathrm{no}=0$ ) & 0.10 & 0.31 & 0 & 1 \\
\hline Number of visits by government agriculture extension service/month & 0.80 & 0.94 & 0 & 4 \\
\hline Source of agricultural-credit (government bank: yes $=1 ;$ no $=0$ ) & 0.16 & 0.36 & 0 & 1 \\
\hline $\begin{array}{l}\text { Source of agriculture information (agriculture-extension, village committee, } \\
\text { newspaper/TV/Radio }=1 \text {; otherwise }=0 \text { ) }\end{array}$ & 0.16 & 0.37 & 0 & 1 \\
\hline
\end{tabular}



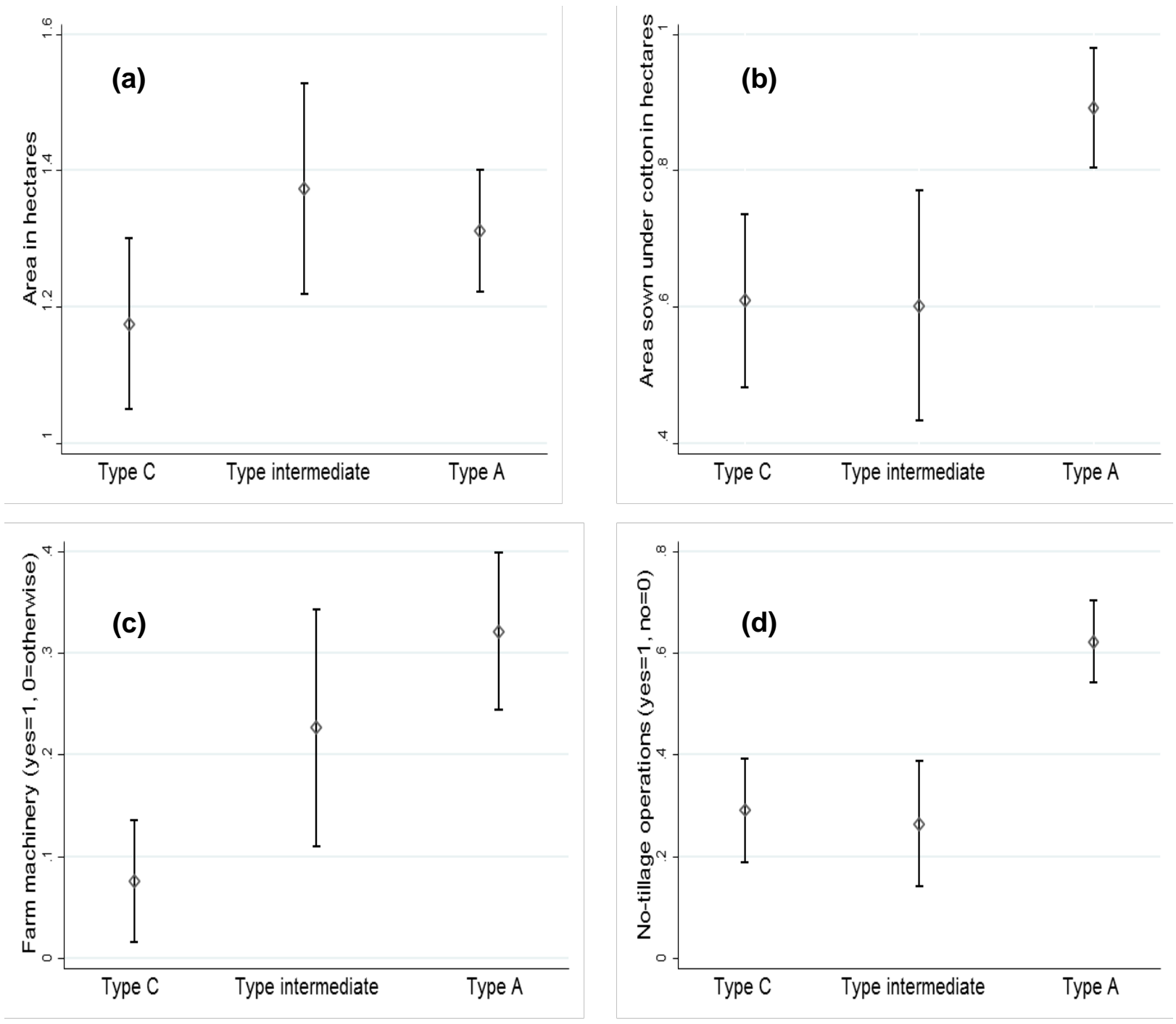

Figure 2. 2. (a)/(b)/(c)/(d): $95 \%$ confidence interval plots of farm capital variables with respect to agrochemical inputs types

While the total farm size of farms exclusively using improved agrochemical inputs (type A) is not necessarily bigger than intermediate and type $\mathrm{C}$ farms, they have a higher mean area under cotton (Fig. 2.2 (a)/(b)). Ownership of farm machinery and no-tillage cropping also tends to be higher for type A farms (Fig. 2(c)/(d)). The same trend can be seen for education of the household head, number of adopters in the neighbourhood, and visits by agricultural extension service agents/month (Fig. 2.3a/b/c). In contrast, the distance to the home of the village head decreases (Fig. 3(d)). For all variables, ANOVA with post hoc Scheffé test indicates that type C farms differ from type A farms. 

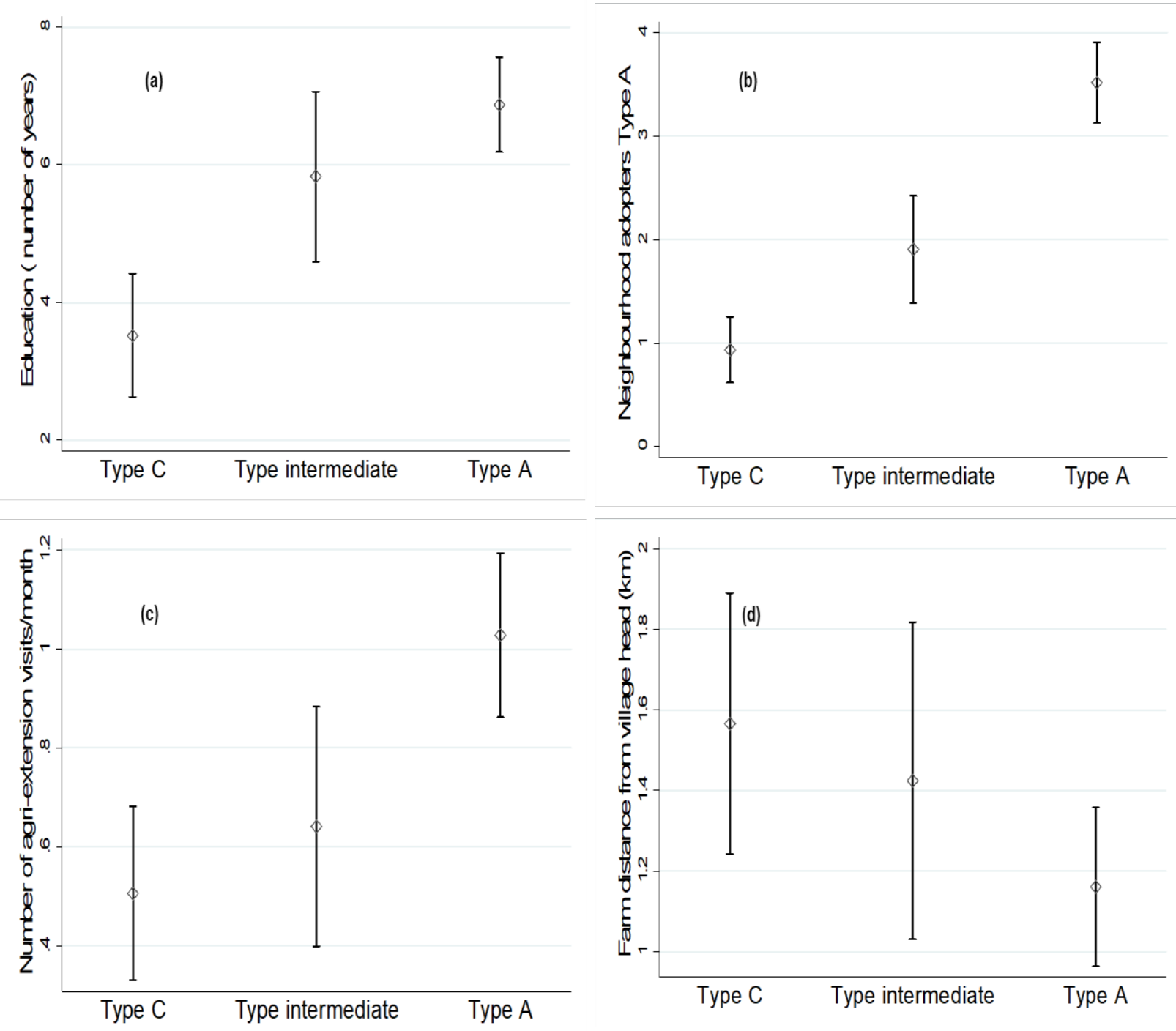

Figure 2. 3. (a)/(b)/(c)/(d): $95 \%$ confidence interval plots of farmers' capital variables with respect to agrochemical inputs types

\subsubsection{Determinants adoption: ordered probit model}

Table 2.5 reports regression estimates of the adoption of agrochemical inputs types from an ordered probit model. The area sown under cotton positively influences the probability of adoption of improved inputs by $13 \%$ per hectare; the probability of using intermediate quality $(-4 \%)$ and base quality $(-9 \%)$ decreases. Owning farm machinery tends to promote type A adoption strongly $(+15 \%)$, while farms are less likely to use exclusively type $\mathrm{C}$ base quality inputs (-9\%). Smallholder farming households practicing no-tillage are (20\%) more likely to exclusively adopt type A inputs - with correspondingly decreasing probabilities for intermediate quality (-6\%) and base quality (- 
$13 \%$ ) inputs. Structurally similar effects are found for the numbers of neighbourhood adopters, age, education, availability of off-farm income, and the number of agricultural extension visits. Of these, the last two have the strongest positive impact on the probability of exclusive type A adoption. Most importantly, one additional visit of an extension agent increases the probability of exclusive type A adoption by $10 \%$ while decreasing the adoption probabilities for both other input quality types. Having agricultural credit from a government bank tends to reduce the probability of exclusive type A adoption (-14\%). As far as the model's accuracy is concerned, we failed to reject the null hypothesis that predictions squared have no explanatory power because of the probability value greater than $10 \%$, we conclude that our model accurately fit the data as presented in Table 2.5.

Table 2.5. Regression estimates of agrochemical inputs categories from an ordered probit model

\begin{tabular}{|c|c|c|c|c|c|}
\hline \multirow[b]{2}{*}{ Explanatory variables } & \multirow[b]{2}{*}{ Coefficients } & \multirow[b]{2}{*}{ Robust SE } & \multicolumn{3}{|c|}{ Marginal Effects } \\
\hline & & & $\mathrm{y}_{\mathrm{i}}=0$ & $\mathrm{y}_{\mathrm{i}}=1$ & $y_{i}=2$ \\
\hline Area in ha (total crop area) & -0.08 & 0.17 & 0.02 & 0.01 & -0.03 \\
\hline Area in ha (cotton) & $0.34 * *$ & 0.15 & $-0.09^{* *}$ & $-0.04 * *$ & $0.13 * *$ \\
\hline Farm machinery & $0.39 *$ & 0.22 & $-0.09 * *$ & -0.05 & $0.15^{*}$ \\
\hline Tube well & -0.24 & 0.25 & 0.07 & 0.02 & -0.09 \\
\hline No-tillage & $0.50 * * *$ & 0.18 & $-0.13 * * *$ & $-0.06 * * *$ & $0.19 * * *$ \\
\hline Neighbourhood adopters & $0.31 * * *$ & 0.05 & $-0.08 * * *$ & $-0.04 * * *$ & $0.12 * * *$ \\
\hline Age & $0.01 *$ & 0.00 & $-0.00 *$ & $-0.00 *$ & $0.00 *$ \\
\hline Education in years & $0.04 * *$ & 0.02 & $-0.01 * *$ & $-0.00 *$ & $0.01 * *$ \\
\hline Off-farm income & $0.33 * *$ & 0.17 & $-0.08 * *$ & $-0.04 *$ & $0.13 * *$ \\
\hline Membership & 0.11 & 0.28 & -0.02 & -0.01 & 0.04 \\
\hline Agriculture information quality & -0.18 & 0.23 & 0.05 & 0.02 & -0.07 \\
\hline Agricultural extension visits & $0.25^{* * *}$ & 0.10 & $-0.06 * * *$ & $-0.03 * *$ & $0.10^{* * *}$ \\
\hline Source of agricultural credit & $-0.36^{*}$ & 0.21 & 0.10 & $0.03 * *$ & $-0.14^{*}$ \\
\hline Farm distance from village head & -0.07 & 0.06 & 0.01 & 0.00 & -0.02 \\
\hline Threshold parameters $\gamma_{1}$ & $1.25 * * *$ & 0.42 & & & \\
\hline Threshold parameters $\gamma_{2}$ & $2.01 * * *$ & 0.43 & & & \\
\hline \multicolumn{6}{|l|}{ Model summary } \\
\hline No. of observations & 275 & & & & \\
\hline Pseudo $\mathrm{R}^{2}$ & 0.25 & & & & \\
\hline Wald $\chi^{2}$ (14 d.f.) & $119.47 * * *$ & & & & \\
\hline Linktest hatsq $p$-value & 0.263 & & & & \\
\hline Log-likelihood & -209.76 & & & & \\
\hline
\end{tabular}

Notes: $* * * \mathrm{p}<0.01 ; * * \mathrm{p}<0.05 ; * \mathrm{p}<0.1$ 


\subsection{Discussion}

Most of the variables incorporated in this study are consonant to previous studies regarding technology adoption in developing countries of South Asia and Africa (Qaim and Kouser, 2013; Abdulai and Huffman, 2014). As the study confined to smallholder farming households, they lack tendency to ownership of farming capital stock (Mottaleb et al., 2017) and we have found a similar trend of that particular variable (e.g., less ownership of farm machinery and tube well). Small farmers are rarely members to farming community groups (Shikuku et al., 2017) also this may be a potential reason of not having a good representation for the membership of local farmers unions (see Table 2.4).

Differentiating three quality types in the adoption of agrochemical inputs by smallholders' famers in Punjab Province, Pakistan, we estimated the econometric influence of several farm capital and farmer capital variables on the adoption of improved quality inputs using an ordered probit model. As expected, farm capital variables such as cotton farm size, ownership of farm machinery, but also off-farm income increased the probability for exclusive adoption of improved quality inputs. Positive technology adoption effects were shown, for instance, for farm size (Bonabana-Wabbi, 2002), area under cotton (Lambert et al., 2015), farm machinery (Morris et al., 1999; Ayandiji and Olofinsao, 2015), and off-farm income (Hailu et al., 2014). These results follow the general pattern that potentially beneficial rural innovations are not first adopted by those most in need but by those able to afford the innovation. Furthermore, our results showed that age is positively associated with input type A adoption. Smallholder age may act as proxy for farming experience, and as such foster's adoption. Asfaw et al. (2012a) find the same positive influence of age on adoption of agricultural technologies. Years of education is a farmer capital variable with five additional years resulting in a high probability of exclusive type A adoption. Years of education have frequently been shown to be positively correlated with adoption of improved quality inputs (cf. Willy and Holm-Müller, 2013).

All of the above variables are characterised by a small or absent short-term ability of the government of a low-income country such as Pakistan to improve variable values. Thus, it is one of the most striking results of our study that the number of contacts of smallholders with agricultural extension service agents has a very strong positive influence on the adoption of improved quality agrochemical inputs: One additional visit per month is associated with a $10 \%$ 
increase in the probability of exclusively adopting quality type A inputs. This result is in line with findings, e.g., by Handschuch and Wollni (2016) showing that extension contacts promote the adoption of improved farm practices. Agricultural extension services help farmers to diversify their knowledge and experience new technologies resulting in a generally positive association with the adoption of new agricultural technologies (Mwangi and Kariuki, 2015; Simtowe et al., 2016). In particular, underprivileged and uneducated farmers can benefit from extension field staff and farmer field schools in association with adult education (Ashraf et al., 2015). Although implementing a well-run and effective nationwide agricultural extension service has its own challenges (Abbas et al., 2003; Aldosari et al., 2017), this is clearly an area deserving prime government attention for short-term and medium-term improvements. With positive neighbourhood effects clearly shown in our data (cf. Wilson, 1987; Holloway et al., 2007), improved agricultural extension may have self-enhancing effects on adoption.

Access to agricultural credit is another area of government activity believed to foster technology adoption (Hailu et al., 2014). One of these institutions in Pakistan is Zarai Taraqiati Bank Limited (ZTBL). Surprisingly, having credit from a government bank reduces the exclusive adoption of type A inputs in our study. One set of reasons may relate to bureaucratic hurdles to government credit (Bilal et al., 2015). In effect, the more successfully adopting farmers eschew government lending institutions. Because of the lack of a positive influence of government credit on adoption, we cannot recommend easier access to government banks as a means to higher adoption. Still, the unusual result may hint at specific problems with the lenders in the project area.

Farmers who perceive that technology meets their needs are likely to adopt the technology (Doss, 2003; Mignouna et al., 2011). Particularly, no-tillage systems are efficient for soil conservation and reduce labour and energy input as ploughing/tillage is avoided (Barbera et al., 2012). No-tillage systems are frequently based on the use of glyphosate formulations - often imported from China or OECD countries and, thus, categorised as improved quality type A agrochemical inputs in our application of official Pakistani classifications. We suggest that the strong influence of no-tillage cropping on adoption is based on the associated use of imported herbicides based on glyphosate or similar ingredients. A discussion of the pros and cons of the joint adoption of no-tillage systems with glyphosate formulations is beyond the scope of this study (see, e.g., Fernandez-Cornejo et al., 2012; Brookes et al., 2017; Danne et al., 2019). 
From scientific point of view, this study conforms - to the best of our knowledge - for the first time that the adoption of improved quality agrochemical inputs follows the same patterns as the initial adoption of agrochemical inputs. This result also holds with respect to influences on the adoption of agricultural innovations at large.

\subsection{Conclusions}

The results demonstrate that several FFC variables significantly impact decisions of smallholders in the cotton-wheat zone of the Punjab to adopt improved quality agrochemical inputs. The results are broadly in line with previous research investigating initial adoption of agrochemical inputs and/or adoption of improved agricultural technologies at large. Of the variables tested, the number of visits by agents of the agricultural extension service had a very strong impact on adoption. Because this is a variable under rather direct and government control that can be improved at moderate cost, we suggest that Pakistani and Punjabi agricultural administrations focus on improvements here. 


\title{
3 Multinational brands versus generic crop protection products: Does the choice matter for the food security of cotton-wheat farmers in Pakistan?
}

\begin{abstract}
A rigorous assessment of the quality of available technologies and outcomes in developing countries is lacking. We investigate the role of multinational brands crop protection products versus generic crop protection products in ensuring smallholder food security. We survey 275 smallholder farming households from the cotton-wheat zone of Punjab province, Pakistan. Food security outcomes are assessed by the Household Food Insecurity Access Scale (HFIAS). We employ an endogenous switching probit model for binary adoption decisions with the inclusion of a selection instrument to account for observed and unobserved heterogeneity. Full information maximum likelihood estimates illustrate that adoption of multinational brands crop protection products is guided by comparative advantage.
\end{abstract}

We find statistically significant evidence of heterogeneity; heterogeneity effects are significantly higher for smallholder farming households that actually adopted relative to those that did not adopt. In particular, agricultural extension information via radio has a significant and positive relationship on adoption. For policy implications based on these results, we suggest agricultural extension can effectively expedite the process of agricultural information dissemination via radio, which may aid to dispel the institutional constraint of lack of extension staff. In sum, this paper suggests that adoption of multinational brands crop protection products enhances food security and can play a key role in the current debate of sustainable intensification, particularly for smallholder farming households.

Keywords: food security, multinational brands crop protection products, smallholders, sociodemographic

JEL classifications: C31, C36, O12, O33, Q12, Q18

This chapter is co-authored by Bernhard Brümmer (BB) and Jan Barkmann (JB). The contribution of each is as follows: Muhammad Bilal (MB) and JB conceptualized the design of the research. MB carried out survey and collected data with the help of two local data collectors. MB analysed data and interpreted. BB and JB assisted in interpretations, constructive comments, and important feedbacks at various stages of the research and drafting of this paper.

Acknowledgements: Financial support was offered by the Foundation fiat panis (project no: 29/2017). This research was supported by a grant from the Higher Education Commission of Pakistan (overseas-scholarship reference: 91591599). We wish to acknowledge the suggestions of Dr. Marwan Benali and Prof. Xiaohua of George August University, Goettingen, Germany. 


\subsection{Introduction}

Rural communities of Pakistan are characterized by a rural poverty syndrome including large household size with low per person land holdings, low agricultural yield per unit area, lack of farm capital, lack of communication between farmers and extension service agents, use of substandard/non-recommended crop protection products, and food insecurity (Khan et al., 2012; Ali et al., 2013; Khan et al., 2013; Rehman et al., 2015; Bilal and Barkmann, 2019). Particularly, food insecurity is high for a substantial fraction of the Pakistani rural population with $61 \%$ of rural households being food insecure (The Government of Pakistan, 2019a). Food security is at alarmingly low levels in Pakistan for a lower-middle-income country: Pakistan only ranks $77^{\text {th }}$ of the $113^{\text {th }}$ countries covered by the Global Food Security Index (GFSI, 2019). Another recent report on the Global Hunger Index (GHI) ranks Pakistan $106^{\text {th }}$ out of $119^{\text {th }}$ developing countries (GHI, 2019).

Technology adoption can be an essential aspect of achieving agricultural sustainability and food security (Vergragt, 2006). Empirical studies show that the use of technologically improved products can enhance farm productivity, and can play a crucial role to enhance food security of smallholder farming households (Nyyssola et al., 2014; Kassie et al., 2015). The most previous studies related to the outcomes of technology adoption highlight the impact of improved verities, genetically modified (GM) crops, improved storage technologies, and extension services in extending food security of smallholder farming households of South Asia and Africa (Mendola et al., 2007; Elias et al., 2013; Negash and Swinnen, 2013; Qaim and Kouser, 2013; Kabunga et al., 2014; Shiferaw et al., 2014; Ricker-Gilbert and Jones, 2015; Simtowe et al., 2016; Tesfaye and Tirivayi, 2018). Many issues on the adoption of improved technological products, particularly, the quality of crop protection products (for example insecticides, fungicides, and herbicides) as well as adoption outcomes in terms of improving food security, still need to be explored (Muzari et al., 2012; Carvalho, 2017; Niles and Salerno, 2018; Bilal and Barkmann, 2019).

In many low-income and middle-income countries, crop protection products are contaminated by hazardous substances or have insufficient declarations and/or safety and usage information which led to the establishment of international conventions to eliminate the usage of highly hazardous substances (for example Montreal Protocol, Rotterdam Convention, Stockholm Convention) (FAO and WHO, 2016). Pakistan is a signatory of the Rotterdam Convention on prior informed consent 
procedure for certain hazardous chemicals and crop protection products since 1999 and signatory of Stockholm Convention on persistent organic pollutant since 2001 (Rotterdam Convention, 2019; Stockholm Convention, 2019). However, the literature about the quality of crop protection products in Pakistan shows the presence of outdated ingredients or low-quality formulations, low and/or unpredictably variable concentration of active agents (Khan et al., 2013; Bilal and Barkmann, 2019). Therefore, crop protection product adulteration is an issue in Pakistan (Nafees et al., 2008), and mishandling is responsible for major water pollution (Azizullah, 2011). Excessive and inappropriate usage induced pests and weeds infestation that has further increased reliance on crop protection products (UNDP, 2001; Tariq et al., 2007; Aga, 2019). These disadvantages may result in lower yields and worse farmer health. Unfortunately, the higher price of higher quality crop protection products and their lack of accessibility may offset the agronomic advantages of higher quality products (Antle and Pingali 1994; Lee, 2005; Aktar et al., 2009; Government of Punjab, 2015; Aga, 2019).

The adoption of improved agricultural technology and its efficient utilization is often facilitated by organisations such as agricultural extension services (Rogers, 1983). In disseminating the information of improved agricultural technology and modern ways of farming, the government of Pakistan much relies on agricultural extension services (Saqib and Tachibana, 2014; Baloch and Thapa, 2016). Likewise, institutions are very important in the quality assurance of agricultural inputs. In Pakistan, mainly the Department of Plant Protection of the Ministry of National Food Security and Research, Pakistan deals with this subject (The Government of Pakistan, 2018a).

According to the Department of Plant Protection Ministry of National Food Security and Research, Pakistan, there are three different types of crop protection product registrations based on product quality and a procedural check.

- Type 1 category broadly termed as generic crop protection products, there are no field trials before their marketing permission and this involves only sample analysis.

- Type 2 is based on field trials prior to registration. The field trials are conducted in two crop seasons before Type 2 final inception and allocating a trade name.

- Type 3 can be broadly termed as multinational crop protection products. The type is based on a registration in the country of origin. An import permission is granted to type 3 crop protection products if they have their origin in an OECD country (Organization 
for Economic Cooperation and Development) or China, and are properly registered their (The Government of Pakistan, 2018a).

In addition to the above-mentioned institutional role in technology adoption, it is important to acknowledge institutions for implementing agricultural research and development (R\&D) activities (Naseem et al., 2006; Anandajayasekeram, 2011). About one-third of investment in agricultural R\&D globally directed towards crop protection products (Pray and Fuglie, 2001). The multinational brands crop protection products (hereafter MBC) may translate as improved crop protection products because products formulation generally follows high standards in terms of research and development (R\&D; Thirtle et al., 2005; Alston, 2010). Furthermore, the adoption of branded products shows an attraction for consumer due to products information, products specification, and packaging attributes (Lewis et al., 2016). To the contrary, generic crop protection products (hereafter GC) may be called substandard crop protection products because generic firms generally lacks R\&D departments (Piesse and Thirtle, 2010; Khan and Khattak, 2013). Additionally, GC may include outdated ingredients or low-quality formulations, low and/or unpredictably variable concentration of active agents, lacking and/or insufficient declarations, safety, and usage information (Khan et al., 2013; Hashmi, 2016).

Against this diversity of crop protection products of varying quality, it is surprising to find that we could not identify any scientific paper that - to our knowledge - specifically investigates the potential advantages of using MBC over other types for smallholder food security.

There are a few studies on the impact of the adoption of crop protection products in general on productivity. For example, Hameed et al. (2017) showed that the adoption of herbicides (for example glyphosate and paraquat formulations) for weed management is positively associated with cotton yield in Pakistan. However, explicit origin and qualitative aspects of the investigated herbicides are not discussed. A highly relevant study by Kouser and Qaim (2014) highlights the importance of optimal levels of pesticide use, and of the adoption of $B t$ cotton on productivity in Pakistan. The study is limited to the synergy of the quantity of pesticide usage and $B t$ cotton. We extend to this literature by focusing more explicitly on the quality of crop protection products. Specifically, we investigate smallholder farming households from the cotton-wheat zone, Punjab, Pakistan, to elucidate quality impacts on food security. 
To the best of our knowledge, this paper is the first empirical ex-post impact assessment on the effect of MBC adoption on household-level food security in Pakistan. Food security outcomes are assessed via the self-reported Household Food Insecurity Access Scale (HFIAS). HFIAS was firstly used by Food and Nutrition Technical Assistance (FANTA), a USAID-funded project in the year 2006. HFIAS is adapted from a United States Household Food Security Survey Module (HFSSM). HFIAS consists of nine-questions, which capture household access to food (Coates et al., 2007). HFIAS is widely used in several countries including developing countries of Africa and Asia (Chinnakali et al., 2014; Gebreyesus et al., 2015).

We acknowledge the methodological challenges in ex-post impact assessments. From the econometric point of view, outcomes of technology adoption may be tainted by observed and unobserved heterogeneity (Heckman and Vytlacil, 2007). As adoption may be endogenous, a correlation between adoption and food security cannot plainly be interpreted as a causal effect of adoption on food security; unobserved sources of heterogeneity may be present. Thus, possible self-selection due to farm level attributes and farming household attributes may create a problem in the assessment of food security effects by MBC adoption. We take this into account when comparing adopters (exclusive MBC use) to non-adopters (use of generic products/otherwise). We employ endogenous switching regression (endogenous switching probit model) by full information maximum likelihood (FIML) to account for the endogeneity.

In experimental studies, the farmers are randomly assigned to adopters and non-adopters. But here we deal with non-experimental studies. Therefore, we include selection instruments which helps to identify the effect of an adoption decision but which is exogenous to food security outcomes (Heckman and Vytlacil, 2007). Without such an identification strategy, the estimation of the effect of MBC adoption on outcomes may be biased.

In nutshell, this paper reduces the knowledge gap about food security triggered by the adoption of MBC. We, therefore, attempt to answer the specific research question: Does the adoption of MBC affect the food security of smallholder farming households? The paper is structured as follows: In section 2, we introduce study site, sampling methodology, dependent and independent variables, and details of HFIAS and in section 3 the overall conceptual and methodological framework. Section 4 covers the results and discussion focusing more on an institutional role in technology 
adoption as well as on policy implications for the agricultural administration of Pakistan. Section 5 concludes with policy recommendations and prospects for future research.

\subsection{Methodology}

\subsubsection{Study site and sampling methodology}

Punjab province contains 58\% of the total cultivated area of Pakistan. The population of Punjab is 101 million; literacy rate of rural Punjab is standing at $55 \%$ (males: $66 \%$; females: $44 \%$ ). The shares of Punjab in the total production of major crops in Pakistan are as follows; cotton 72\%, rice $52 \%$, sugarcane $65 \%$, and wheat $76 \%$ (The Government of Punjab, 2015; The Government of Pakistan, 2019a). The cotton-wheat zone of Punjab province is an important retail market for crop protection products. According to the Punjab Bureau of Statistics, farms with area $\leq 5$ acres $(\sim 2.02$ hectares) are considered small farms. Smallholder farming households characterize much of the Punjabi farm population (The Government of Punjab, 2010).

The cotton-wheat zone comprises three important agricultural divisions (division is the highest administrative unit) of Punjab province: the Bahawalpur division, the Multan division, and the Sahiwal division. We employed multistage random sampling with the probability of selection of a farming household being proportional to population accounting for the availability and accessibility of crop protection product types.

Firstly, from each division we randomly selected one district Pakpattan, Rahimyar Khan, and Vehari. Secondly, from each district we randomly selected one tehsil (below district administrative unit/ subdistrict) Burewala, Pakpattan, and Sadiqabad. Lastly, six villages from each subdistrict make 18 villages in total (see Fig. 4.1). A total of $N=275$ small farming households were interviewed in 18 randomly selected villages. 


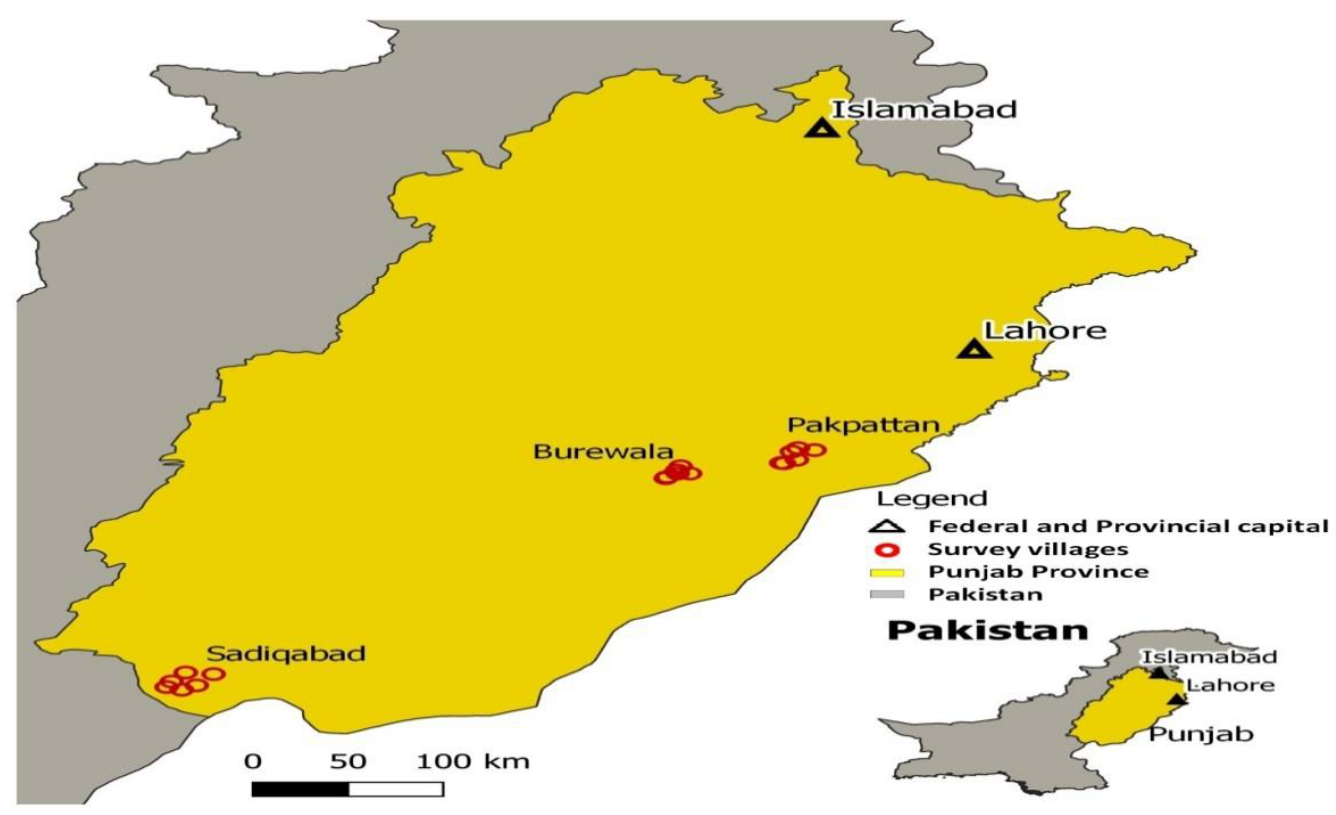

Figure 3. 1. Spatial locations of surveyed villages in three randomly selected subdistricts (tehsils) of Punjab

Source: Made by the first author using QGIS software.

We sampled socio-demographic, farm-specific and food security data (HFIAS) as well as the adoption status of $\mathrm{MBC}, \mathrm{GC}$ or other crop protection products.

\subsubsection{Description of dependent variables}

The dependent variable for the selection equation is adoption status: adopters (exclusive MBC use, coded 1) and non-adopters (use of GC/otherwise, coded 0). Within the econometric framework, adopters are also referred to as the "treated" group and non-adopters as the "untreated" group. The dependent variable for the outcome's equation is food security status: exclusive food secure households (HFIAS total score $=0$ "zero", translates for exclusive food secure=1) and food insecure households (HFIAS total score $\geq 1$, translates food insecure=0). Table 3.1 presents the frequency of total sample distribution into adoption status and food security status. 
Table 3.1. Adoption and food security status of sampled households

\begin{tabular}{lccc}
\hline Adoption status & \multicolumn{3}{c}{ Food security status (HFIAS total score = 0 "zero" = exclusive food secure) } \\
& Exclusive food secure households=1 & Food insecure households=0 & Total \\
\hline Adopters (MBC=1) & 86 & 57 & 143 \\
Non-adopters (GC/otherwise=0) & 26 & 106 & 132 \\
Total & 112 & 163 & 275 \\
\hline
\end{tabular}

\subsubsection{The Household Food Insecurity Access Scale (HFIAS)}

To compute the dependent variable for outcomes equation, we use the HFIAS scale successfully applied in developing countries of South Asia and Africa (Chinnakali et al., 2014; Kabunga et al., 2014). HFIAS is a subjective assessment of food insecurity consists of questions concerning the assessment of food access from households (Coates et al., 2007). The HFIAS consists of nine questions about access to food. An affirmative answer to any question adds one to a sum total. Thus, the HFIAS scores range from 0 to 9. Advantages of HFIAS include its proven applicability across cultures and its low data requirement (Kabunga et al., 2014; Gebreyesus et al., 2015).

However, subjective assessment may induce response bias (Headey and Ecker, 2013). To reduce response biases, we asked smallholders to outline their main agricultural activities during the agricultural calendar year before asking HFIAS questions. Typical activities include land preparation, harvesting, threshing, buying and selling of milk animals, buying of crop protection products. Moreover, we asked smallholders to identify the months during which they expect grain or food shortage.

For the robustness check about the response from HFIAS, we employ principal component analysis because of the high correlation among the responses. The analysis results to retain two components because of the minimum advisable eigenvalue of above unity (Kaiser, 1960). Component one loaded mainly on first five questions that may reflect "food insecure" while component two loaded mainly on last three questions that may reflect "severely food insecure" (see Table A3.1 in the Appendix A3). The scale reliability coefficient was tested by the Cronbach alpha statistic and value for the scale was $\alpha=0.95$, we also observed the Kaiser-Meyer-Olkin (KMO) measure of sampling adequacy $=0.89$, suggesting the data adequacy for component analysis. 
The information extracted from these components could have been used as a continuous ${ }^{7}$ dependent variable for outcomes equation. However, failing to find sufficient selection instruments, we prefer a binary ${ }^{8}$ dependent variable for outcomes modelling. Therefore, we classify smallholder exclusively into two categories with respect to their food security status namely, exclusively food secure households and food insecure households.

The construction of a binary dependent variable based on subjective assessment is greatly supported by the recent past studies. For example, Tesfaye and Tirivayi (2018) constructed binary dependent variable for outcomes equation using HFIAS information. Moreover, closely following the existing literature on self-assessment and subjective assessment of food security by Shiferaw et al. (2014) and Khonje et al. (2015) have had used binary dependent variable for food security outcomes.

\subsubsection{Description of independent variables}

The detailed descriptive statistics are presented in Table 3.2. The results of two-sample meancomparison tests indicate statistically significant differences between adopters and non-adopters (off-farm income sources, farm machinery, seasonal labour, and agricultural extension information via radio). No substantial difference is observed, e.g., for the total number of males and females in a household, the number of milk animals, agricultural area).

Table 3.2 includes socio-demographic and farming capital variables. The selection of variables is guided by empirical studies and economic theory (cf. Tesfaye and Tirivayi, 2018; Shiferaw et al., 2014; Abdulai and Huffman, 2014; Kassie et al., 2011). The source of agricultural information is very important to keep farmers up-to-date about the development in agriculture sector (Bilal and Barkmann, 2019). At first glance, our sample indicates that adopters listen to the radio more frequently to acquire agriculture extension service information and they have more years of schooling than non-adopters (cf. Asfaw et al., 2012b; Khonje et al., 2015). Similarly, the sample mean of average ownership of farm machinery is significantly higher for adopters than for nonadopters (cf. Di Falco et al., 2011; Kabunga et al., 2014).

\footnotetext{
7 The estimations with continuous dependent outcomes variable require movestay command (Lokshin and Sajaia, 2004) and also requires fulfilling the assumption of exclusion restriction to validate selection instruments (Aakvik et al., 2005), regretfully we failed to find the sufficient selection instruments for continuous dependent variable for outcomes equation.

${ }^{8}$ We used switch_probit command (Lokshin and Sajaia, 2011) that is flexible for binary dependent outcomes variable. The estimations were carried out using STATA version 15.
} 
Table 3.2. Descriptive statistics of variables

\begin{tabular}{|c|c|c|c|c|c|c|c|}
\hline \multirow[b]{2}{*}{ Variables names } & \multicolumn{2}{|c|}{$\begin{array}{l}\text { Full sample } \\
(N=275)\end{array}$} & \multicolumn{2}{|c|}{$\begin{array}{c}\text { Adopters }=1 \\
(N=143)\end{array}$} & \multicolumn{2}{|c|}{$\begin{array}{c}\text { Non-adopters }=0 \\
(N=132)\end{array}$} & \multirow[t]{2}{*}{ Diff } \\
\hline & Mean & $\mathrm{SD}$ & Mean & SD & Mean & SD & \\
\hline \multicolumn{8}{|l|}{ Socio-demographic variables } \\
\hline Age in years & 43.53 & 12.92 & 44.17 & 12.94 & 42.84 & 12.90 & -1.33 \\
\hline Marital status (yes=1; no=0) & 0.84 & 0.36 & 0.81 & 0.39 & 0.88 & 0.31 & $0.07 *$ \\
\hline Education (years of schooling) & 5.70 & 4.41 & 6.87 & 4.17 & 4.44 & 4.33 & $-2.42 * * *$ \\
\hline Household size (Hh size) & 7.62 & 3.39 & 7.58 & 3.21 & 7.66 & 3.59 & 0.08 \\
\hline Total number of males in $\mathrm{Hh}$ & 3.39 & 1.97 & 3.45 & 1.93 & 3.33 & 2.02 & -0.12 \\
\hline Total number of females in $\mathrm{Hh}$ & 4.22 & 2.23 & 4.12 & 2.08 & 4.33 & 2.38 & 0.20 \\
\hline Total adult family labour (agri-farming) & 1.52 & 0.82 & 1.53 & 0.83 & 1.50 & 0.80 & -0.03 \\
\hline Hired labour (permanent, yes=1; no=0) & 0.10 & 0.30 & 0.13 & 0.34 & 0.07 & 0.26 & -0.05 \\
\hline Total seasonal labour male (agri-farming) & 2.85 & 2.76 & 3.41 & 3.09 & 2.23 & 2.22 & $-1.18 * * *$ \\
\hline Total seasonal labour female (agri-farming) & 3.80 & 3.21 & 4.62 & 3.37 & 2.91 & 2.76 & $-1.70 * * *$ \\
\hline Access to credit (yes $=1 ;$ no $=0$ ) & 0.41 & 0.49 & 0.39 & 0.48 & 0.43 & 0.49 & 0.04 \\
\hline Credit received $($ yes $=1 ;$ no $=0)$ & 0.29 & 0.45 & 0.23 & 0.42 & 0.35 & 0.48 & $0.11 * *$ \\
\hline Credit from government bank (yes $=1 ;$ no= 0 ) & 0.16 & 0.36 & 0.13 & 0.34 & 0.18 & 0.39 & 0.05 \\
\hline Agri-extension-info via radio $(\mathrm{yes}=1 ; \mathrm{no}=0$ ) & 0.26 & 0.44 & 0.32 & 0.46 & 0.19 & 0.39 & $-0.12 * *$ \\
\hline Cell phone own $($ yes $=1 ;$ no $=0)$ & 0.10 & 0.31 & 0.11 & 0.31 & 0.10 & 0.30 & -0.005 \\
\hline Farm distance from the village head $(\mathrm{km})$ & 1.32 & 1.32 & 1.16 & 1.18 & 1.50 & 1.43 & $0.34 * *$ \\
\hline Farm distance from the main road $(\mathrm{km})$ & 1.10 & 1.07 & 0.98 & 1.13 & 1.23 & 1.00 & $0.25^{*}$ \\
\hline Number of males involved in off-farm income & 0.60 & 0.77 & 0.65 & 0.74 & 0.55 & 0.80 & -0.10 \\
\hline Off-farm income sources $(y e s=1 ;$ no $=0$ ) & 0.45 & 0.49 & 0.51 & 0.50 & 0.39 & 0.49 & $-0.12 * *$ \\
\hline Region1 (if Vehari =1; otherwise $=0$ ) ${ }^{\mathrm{a}}$ & 0.29 & 0.45 & 0.36 & 0.48 & 0.21 & 0.41 & $-0.15 * * *$ \\
\hline Region2 (if Rahimyar Khan $=1$; otherwise $=0$ ) ${ }^{\mathrm{b}}$ & 0.38 & 0.48 & 0.41 & 0.49 & 0.35 & 0.48 & -0.05 \\
\hline Region3 (if Pakpattan $=1$; otherwise $=0)^{\mathrm{c}}$ & 0.32 & 0.46 & 0.22 & 0.41 & 0.43 & 0.49 & $0.20 * * *$ \\
\hline \multicolumn{8}{|l|}{ Farming capital variables } \\
\hline Area in acres ( 1 acre $\sim 0.404$ hectares) & 3.20 & 1.38 & 3.27 & 1.35 & 3.13 & 1.41 & -0.14 \\
\hline Area wheat in acres & 2.29 & 1.28 & 2.38 & 1.31 & 2.19 & 1.24 & -0.18 \\
\hline High quality wheat seed (yes=1; no=0) & 0.60 & 0.48 & 0.74 & 0.43 & 0.45 & 0.49 & $-0.29 * * *$ \\
\hline Area sown cotton in acres & 1.88 & 1.43 & 2.09 & 1.37 & 1.51 & 1.46 & $-0.71 * * *$ \\
\hline Cotton seed if $B t($ yes $=1 ;$ no $=0)$ & 0.65 & 0.47 & 0.80 & 0.39 & 0.49 & 0.50 & $-0.31 * * *$ \\
\hline Area sown other crops in acres & 1.27 & 1.77 & 1.05 & 1.62 & 1.50 & 1.90 & $0.44 * *$ \\
\hline Area cotton-wheat in acres & 4.17 & 2.32 & 4.60 & 2.33 & 3.71 & 2.22 & $-0.89 * * *$ \\
\hline Own capital stock (yes $=1 ;$ otherwise $=0$ ) & 0.73 & 0.44 & 0.78 & 0.41 & 0.68 & 0.46 & $-0.10^{*}$ \\
\hline Farm machinery $($ yes $=1$; otherwise $=0$ ) & 0.23 & 0.42 & 0.32 & 0.46 & 0.13 & 0.34 & $-0.18 * * *$ \\
\hline Number of milk animals & 1.26 & 1.60 & 1.20 & 1.37 & 1.31 & 1.82 & 0.10 \\
\hline
\end{tabular}

Notes: The level of significance is $* * * \mathrm{p}<0.01$, ${ }^{*} \mathrm{p}<<0.05,{ }^{*} \mathrm{p}<0.1$. ${ }^{\mathrm{a}}$ Region 1 and ${ }^{\mathrm{c}}$ Region 3 plots in central Punjab, ${ }^{\mathrm{b}}$ Region2 plots in southern Punjab. The average distance between the randomly selected regions of central and southern Punjab is about $400 \mathrm{~km}$ via National Highway.

From the aspect of factor endowments - especially land and labour, the tendency to hire permanent labour, seasonal labour, and the area sown under cotton crop is higher for adopters than for nonadopters. As we exclusively dealt in with small farming households, only $11 \%$ of the total sample hired permanent labour and $\sim 45 \%$ of the total sample have off-farm income sources. 
From a demographic point of view, the distance of smallholder farming household farms to the main road and to house of the village head is significantly smaller for adopters than for nonadopters (cf. Tesfaye and Tirivayi, 2018).

\subsubsection{Conceptual and methodological framework}

Ex post impact assessment studies, where farmers are not randomly assigned into treatment and control group, may result in self-selection bias and leads to the problem of endogeneity (Heckman and Vytlacil, 2007). Sometimes unobserved endogenous variables (for example farm management, personal capabilities and abilities, farming decision) impact both the treatment variables and the outcomes variables, and may lead to endogeneity. One possible solution to account for endogeneity is by invoking a selection instrument to improve identification. The selection instrument is supposed to explain the adoption decision but is exogenous to outcomes variables (Bellemare, 2010). To find a good selection instrument is a difficult task as it has to fulfil the conditions of relevance and exogeneity simultaneously (Kassie et al., 2015).

We use the distance (i) of a smallholder farm to the farm of the village head and (ii) from a smallholder farm to the main road as selection instruments. There is substantial empirical evidence of the positive association of demographic attributes on technology adoption (for example Khonje et al., 2015; Tesfaye and Tirivayi, 2018). Recent impact assessment studies by Dedehouanou et al. (2018) have used the household distance in kilometre $(\mathrm{km})$ to the administrative subdivision as a selection instrument; Krishna et al. (2017) have used the altitude of the place of residence to the sea level in meters as a selection instrument. Our selection instruments are similar to those used in these successful implementations of the method.

We employed proper econometrical procedures to validate the inclusion of selection instruments. Firstly, we constructed a correlation matrix between potential selection instruments and adoption status as well as food security status. Secondly, we considered the relevance and exogeneity conditions for selection instruments and employed relevant diagnostic tests (for example Sargan's test and Anderson canonical correlations statistics). Finally, for the admissibility of exclusion restriction we employ the falsification approach by following Di Falco et al. (2011) on considered selection instruments. The selection instruments must be significantly correlated with adoption decision but not correlated with the outcomes of interest among non-adopter's farm households. A 
Wald test on selection instruments also confirms that these are potential instruments as the test statistics are significant with $\mathrm{P}<1 \%$ (see Table A3.2, A3.3, and A3.4 in the Appendix A3).

In this paper, we use a binary adoption choice, and binary food security outcomes (Tesfaye and Tirivayi, 2018). Farmers who exclusively incorporate MBC are termed as adopters and those who do not are termed as non-adopters. However, adoption is potentially endogenous and this give no causal interpretation of outcomes of interest because of smallholder own choices for adoption. This condition may be affected by unobserved heterogeneity and possible self-selection due to farm level attributes and farming household attributes that may create problems in the assessment of food security gains by the adoption of technology (Kabunga et al., 2014). We tackle this situation and employ an endogenous switching probit model with FIML (Full Information Maximum Likelihood) which is considered an efficient method to estimate the binary selection equation and the binary outcomes equation simultaneously to yield consistent standard errors of the estimates. The model works under the assumption of joint normality of the error terms in the selection and outcomes equations (Lokshin and Glinskaya, 2009; Lokshin and Sajaia, 2011).

We assume that smallholder farming households have the potential to adopt MBC but the response to adoption may vary. We distinguish the response by introducing a criterion function $\mathrm{A}_{\mathrm{i}}$ that determines which regime a smallholder farming household belongs. As discussed above, here the adoption (MBC) and the outcomes (exclusive food secure) have one of two potential values (Aakvik et al., 2005).

$$
\begin{aligned}
& A_{i}=1 \text { if } \alpha J_{i}+\mu_{i}>0 \\
& A_{i}=0 \text { if } \alpha J_{i}+\mu_{i} \leq 0 \\
& Y_{F S i}^{*}=\beta_{F S} X_{F S i}+\varepsilon_{F S i} \quad \text { and } Y_{F S i}=I\left(Y_{F S i}^{*}>0\right) \\
& Y_{N F S i}^{*}=\beta_{N F S} X_{N F S i}+\varepsilon_{N F S i} \text { and } Y_{N F S i}=I\left(Y_{N F S i}^{*}>0\right)
\end{aligned}
$$

The observed $Y_{i}$ is defined as

$$
\begin{aligned}
& Y_{i}=Y_{F S i} \text { if } A_{i}=1 \\
& Y_{i}=Y_{N F S i} \text { if } A_{i}=0
\end{aligned}
$$

In the present case, 
- $Y_{F S i}^{*}$ and $Y_{N F S i}^{*}$ are the latent variables (whether the smallholder farming households are exclusive food secure or not) that determine the observed binary outcomes $Y_{F S i}$ and $Y_{N F S i}$ (smallholder farming households' response to adopt exclusive MBC).

- $X_{F S i}$ and $X_{N F S i}$ are vectors of weakly exogenous variables, for the model to specify correctly the exogenous variables in Eqs. (2) and (3) should be same.

- $\quad \mathrm{J}$ is a vector of variables that determine a switch between the regimes.

- $\quad \beta_{F S}, \beta_{N F S}$, and $\alpha$ are vectors of parameters.

- and $\mu_{i}, \varepsilon_{F S i}$, and $\varepsilon_{N F S i}$ are the error terms under the assumption that $\mu_{i}, \varepsilon_{F S i}$, and $\varepsilon_{N F S i}$ are jointly normally distributed in the context of binary outcomes, with a mean-zero vector and correlation matrix (see Heckman and Vytlacil, 2007; Lokshin and Sajaia, 2011).

- Where $\rho_{N F S}$ and $\rho_{F S}$ are the correlations between $\varepsilon_{N F S i}, \mu_{i}$ and $\varepsilon_{F S i}, \mu_{i}$ and $\rho_{F S N F S}$ is the correlation between $\varepsilon_{N F S i}$ and $\varepsilon_{F S i}$. We assume that $\rho_{F S N F S}=1$ ( $\alpha$ is estimable only up to a scalar factor).

$$
\Omega=\left(\begin{array}{ccc}
1 & \rho_{N F S} & \rho_{F S} \\
& 1 & \rho_{F S N F S} \\
& & 1
\end{array}\right)
$$

We calculate the probabilities of adoption and adoption outcomes in the actual and counterfactual regime. First, the probability of being treated and having positive outcomes is calculated (Eq. 4). Second, the probability of not being treated and having zero outcomes is calculated (Eq. 5). Third, the probability of being treated and having zero outcomes (Eq. 6), and fourth, the probability of not being treated and having positive outcomes (Eq. 7) is computed.

$$
\begin{aligned}
& \operatorname{Pr}\left(A_{i}=1, Y_{F S i} \mid \mathrm{X}=\mathrm{x}\right)=\Phi_{2}\left(\alpha J_{i}, X_{F S i} \beta_{F S}, \rho_{F S}\right)(\text { actual }) \\
& \operatorname{Pr}\left(A_{i}=0, Y_{N F S i} \mid \mathrm{X}=\mathrm{x}\right)=\Phi_{2}\left(-J_{i} \alpha,-X_{N F S i} \beta_{N F S}-\rho_{N F S}\right)(\text { actual }) \\
& \operatorname{Pr}\left(A_{i}=1, Y_{N F S i} \mid \mathrm{X}=\mathrm{x}\right)=\Phi_{2}\left(\alpha J_{i},-X_{F S i} \beta_{F S}-\rho_{F S}\right)(\text { counterfactual }) \\
& \operatorname{Pr}\left(A_{i}=0, Y_{F S i} \mid \mathrm{X}=\mathrm{x}\right)=\Phi_{2}\left(-J_{i} \alpha, X_{N F S i} \beta_{N F S},-\rho_{N F S}\right)(\text { counterfactual })
\end{aligned}
$$


Following Aakvik et al. (2005) and Lokshin and Sajaia (2011), we calculate the effect of the treatment on the treated (TT) summarized in Eq. (8) as the difference of Eqs. (4) - (6). Actually, Eq. (8) represents the effect of exclusive adoption of MBC on the food security outcomes of the farming households that adopted.

$\mathrm{TT}(\mathrm{x})=\operatorname{Pr}\left(Y_{F S i}=1 \mid A_{i}=1, \mathrm{X}=\mathrm{x}\right)-\operatorname{Pr}\left(Y_{N F S i}=1 \mid A_{i}=1, \mathrm{X}=\mathrm{x}\right)$

Following the same procedure, we calculate, the effect of treatment on the untreated (TU) summarized in Eq. (9) as the difference of Eqs. (7) - (5). In fact, Eq. (9) represents the effect of exclusive adoption of MBC on food security outcomes of the smallholder farming households who did not adopt.

$\mathrm{TU}(\mathrm{x})=\operatorname{Pr}\left(Y_{F S i}=1 \mid A_{i}=0, \mathrm{X}=\mathrm{x}\right)-\operatorname{Pr}\left(Y_{N F S i}=1 \mid A_{i}=0, \mathrm{X}=\mathrm{x}\right)$

\subsection{Results}

This section describes the estimates of the endogenous switching probit model estimated by FIML with robust standard errors. The FIML estimates of the endogenous switching probit model are presented in Table 3.3 and Table 3.4.

\subsubsection{Determinants of MBC adoption}

The first column of Table 3.3 presents the estimated coefficients of the selection equation. Those farmers who acquired the agricultural extension service information via radio, have off-farm income generation means, employed seasonal labour for agricultural farming, and own farm machinery were more likely to adopt. From a demographic point of view, the smallholder farming households whose farms were located closer to the main road and closer to the farm of the village head were more likely to adopt MBC. Interestingly, those farming households with a higher number of females in the household, have received credit, and located in Pakpattan (region3) were less likely to adopt MBC. Table A3.5 (see Appendix A3) presents the estimates of variables included in the main model by separate probit models of the selection equation without switching. The dependent variable equals 1 if the smallholder farming households exclusively decided to adopt $\mathrm{MBC}$ and 0 for GC/otherwise. 
Table 3.3. Estimates of the endogenous switching probit model

\begin{tabular}{|c|c|c|c|}
\hline & \multicolumn{3}{|c|}{ Food security status } \\
\hline & $\begin{array}{l}\text { Adoption status } \\
\qquad(1 / 0)\end{array}$ & $\begin{array}{c}\text { Adopter } \\
\text { households }\end{array}$ & $\begin{array}{c}\text { Non-adopter } \\
\text { households }\end{array}$ \\
\hline Total number of males in household & $0.05(0.04)$ & $0.01(0.05)$ & $-0.02(0.07)$ \\
\hline Total number of females in household & $-0.08 *(0.04)$ & $-0.05(0.05)$ & $0.05(0.05)$ \\
\hline Marital status of respondent (yes $=1, \mathrm{no}=0$ ) & $-0.43(0.26)$ & $-0.41(0.27)$ & $-0.44(0.39)$ \\
\hline Agri-extension-info via radio (yes $=1$, no $=0$ ) & $0.43 *(0.26)$ & $0.24(0.24)$ & $0.54(0.50)$ \\
\hline Cell phone own (yes $=1$, no= $=0$ ) & $-0.36(0.36)$ & $-0.33(0.38)$ & $0.60(0.61)$ \\
\hline Number of milk animals & $-0.04(0.05)$ & $0.10(0.07)$ & $0.01(0.07)$ \\
\hline Off-farm income sources $(\mathrm{yes}=1, \mathrm{no}=0$ ) & $0.34 *(0.19)$ & $0.52 * *(0.21)$ & $0.57 *(0.30)$ \\
\hline Credit received (yes $=1$, no $=0$ ) & $-0.38 * *(0.19)$ & $-0.55 * *(0.23)$ & $-0.19(0.32)$ \\
\hline Area in acres $(1$ hectare $=2.47$ acres $)$ & $0.04(0.04)$ & $0.06(0.04)$ & $0.03(0.08)$ \\
\hline Total seasonal labour male (agri-farming) & $0.08 * *(0.03)$ & $0.12 * * *(0.03)$ & $0.05(0.07)$ \\
\hline Total seasonal labour female (agri-farming) & $0.07 * *(0.02)$ & $0.05(0.03)$ & $0.01(0.06)$ \\
\hline Farm machinery $($ yes $=1$; otherwise $=0$ ) & $0.61 * *(0.24)$ & $0.64 * *(0.25)$ & $0.14(0.37)$ \\
\hline Region 1 (if Vehari =1; otherwise=0) & $0.26(0.22)$ & $0.67 * * *(0.25)$ & $-0.93 * *(0.36)$ \\
\hline Region3 (if Pakpattan =1; otherwise=0) & $-0.44 *(0.23)$ & $-0.43(0.27)$ & $-0.54(0.37)$ \\
\hline Farm distance from the village head $(\mathrm{km})$ & $-0.18 * * *(0.06)$ & & \\
\hline Farm distance from the main road $(\mathrm{km})$ & $-0.17 * *(0.07)$ & & \\
\hline Log pseudo likelihood & -277.75 & & \\
\hline pseudo- $R^{2}(N=143)$ & & 0.20 & \\
\hline pseudo- $R^{2}(N=132)$ & & & 0.22 \\
\hline Wald $\chi^{2}(16)$ & $52.92 * * *$ & & \\
\hline Errors correlation coefficients & & $\rho_{F S} 0.99 * * *$ & $\rho_{N F S}-0.39$ \\
\hline Wald test of independent equations $\chi^{2}(2)$ & $7.24 * *$ & & \\
\hline
\end{tabular}

Notes: Robust standard errors are in parentheses, the level of significance is $* * * \mathrm{p}<0.01, * * \mathrm{p}<0.05, * \mathrm{p}<0.1 . \rho$ Fs indicates the errors correlation coefficient for adopters and food secure smallholder farming households and $\rho$ NFS indicates the correlation coefficient for adopters and food insecure smallholder farming households.

\subsubsection{Estimates of the endogenous switching probit model: treatment effects}

In the last row of Table 3.3, we report Wald tests statistics of the joint significance $\left(\rho_{F S}=\rho_{N F S}\right.$ $=0$ ) of the error correlation coefficients in the selection and outcomes equations. The test rejects the null hypothesis that $\rho_{F S}=\rho_{N F S}$ because of the prob $>\chi^{2}=0.02$. Therefore, we are justified employing an endogenous switching probit model to account for endogeneity (Dedehouanou et al., 2018). 
The second last row of Table 3.3 presents the correlation coefficients among error terms. The estimated correlation coefficient $\left(\rho_{F S}\right)$ for adopters and food secure smallholder farming households is significantly different from zero. This may imply that the adoption of MBC had a significant effect on food security, and the adopters would have gained greater benefits from MBC adoption than non-adopters had non-adopters decided to adopt MBC. However, the estimated correlation coefficient $\left(\rho_{N F S}\right)$ for non-adopters is not significantly different from zero. This may imply that adopters and non-adopters have the same value of outcomes provided their observed characteristics.

Additionally, the signs of the correlation coefficients are important to derive economic interpretations. The positive sign of the correlation coefficient between the error terms of adopters and food secure smallholder farming households and the negative sign of the correlation coefficient between the error terms of non-adopters and food insecure smallholder farming households illustrate that adoption of MBC is guided by comparative advantage (Fuglie and Bosch, 1995). This suggests that adopters have higher average values of food security outcomes than non-adopters, and non-adopters also have higher average values of food security outcomes from non-adoption.

The above interpretations of correlation coefficients sign are in line with the estimates of outcomes equation presented in the last two columns of Table 3.3. This indicates the presence of significant differences in both, observed and unobserved characteristics among adopters and non-adopters. The positive effects of the off-farm income sources ${ }^{9}$, seasonal labour, farm machinery ownership, and the region1 (if farmer located in Vehari $=1$, otherwise $=0$ ) on food security status were more prominent among the farmers who exclusively adopted MBC. Surprisingly, the negative effect of credit received $^{10}$ on food security status was also more prominent among the smallholder farming households who exclusively adopt MBC. The positive effect of the off-farm income sources on food security status among adopter and non-adopters were the same but with varying magnitude.

\footnotetext{
${ }^{9}$ We acknowledged the potential endogeneity in the variables i.e., off-farm income sources and the ownership of farm machinery in outcomes equation, failure to find a sufficient instrument, we drop all potentially endogenous variables in outcomes equation from the main model, but interestingly, the magnitude and sign of TT and TU remains almost same (see Table A3.9 and A3.10 in the Appendix A3). Therefore, on the basis of highly significant likelihood ratio test LR $\chi^{2}(12)=35.99$ at less than $1 \%$, we include these variables in the model presented above.

${ }^{10}$ We also investigated potential endogeneity in the variable access to credit for the second model (see Table A3.6 in the Appendix A3), therefore, we use the variable credit received in the model presented above, which translates the number of respondents who actually received credit. The negative sign associated with credit received can be interpreted as respondents who actually received credit are those with low food security status (higher HFIAS score) than those do not actually received credit (Di Falco et al., 2011).
} 
However, the negative effect of region1 on food security status was more apparent among the smallholder farming households who did not exclusively adopt MBC.

Most importantly, Table 3.4 presents the predicted probabilities food security outcomes of smallholder farming households under actual Eqs. (4) and (5) and counterfactual Eqs. (6) and (7) regimes. We report the treatment effects of adoption status on food security status of smallholder farming households in the last column of Table 3.4.

\section{Table 3.4. Treatment effects of $\mathrm{MBC}$ adoption on food security status}

\begin{tabular}{llll}
\hline \multirow{2}{*}{ Sub-samples } & \multicolumn{2}{c}{ Decision stage } & \\
\cline { 2 - 3 } Adopter smallholder farming households & To Adopt & Not to Adopt & Treatment Effects \\
\hline \multirow{3}{*}{ Non-adopter smallholder farming households } & 0.31 & 0.09 & TT $=0.22^{* * *}$ \\
& $(0.01)$ & $(0.00)$ & $(0.01)$ \\
Heterogeneity effects & 0.20 & 0.39 & TU $=-0.19^{* * *}$ \\
& $(0.00)$ & $(0.01)$ & $(0.01)$ \\
& BH1 $=0.11$ & $\mathrm{BH} 2=-0.30$ & TH $=0.41^{* * *}$ \\
\hline
\end{tabular}

Notes: TT stands for the effect of the treatment on the treated, TU for the effect of the treatment on the untreated, $\mathrm{BH} 1$ and $\mathrm{BH} 2$ for base heterogeneity for the smallholder farming households those adopted (MBC) and those did not adopt, and TH for transitional heterogeneity. Standard errors are in parentheses, the level of significance is $* * * \mathrm{p}<0.01, * * \mathrm{p}<0.05, * \mathrm{p}<0.1$

In the counterfactual regime Eq. (6), the smallholder farming households who actually adopted may have 22 percentage points less to food security if they had not adopted. This positive and significant value of TT suggests that adoption to MBC would positively contribute to food security of adopters, and their decision to opt MBC presumably robust and rational. These findings corroborate the finding of recent studies on food security impact of adoption, (for example Tesfaye and Tirivayi, 2018; Shiferaw et al., 2014: Negash and Swinnen, 2013) which states that the adoption of improved storage innovations, adoption of improved wheat varieties, and adoption of castor production as a biofuel crop increases the positive probability of food security of the adopter households.

If the actual non-adopters had adopted, adoption may have reduced food security by 19 percentage points. This result of treatment effect for non-adopters on food security is consistent with Krishna et al. (2017) who find that adoption to oil palm expansion may reduce household welfare by $7 \%$ for actual non-adopters if they had adopted. Similarly, Negash and Swinnen (2013) find that nonadopter households of castor production as a biofuel crop decreases the probability of food security if they had adopted. The finding of Noltze et al. (2013) also suggests that non-adopters would suffer 
from household income loss if they adapted to natural resource management technologies. This negative and significant value of TU suggests that adoption to MBC would not positively contribute to the food security of non-adopters ${ }^{11}$, and their decision not to opt MBC presumably robust and rational. This may indicate the presence of heterogeneity because the transitional heterogeneity effect is positive and significant in the present case. This may depict that base heterogeneity effects are significantly higher for those smallholder farming households that actually did adopt relative to those that did not adopt (cf. Krishna et al., 2017).

In addition to above-mentioned results and discussion we controlled for different explanatory variables (for example total number of adult family labour, age of respondents, hired labour, number of males involve in off-farm, access to credit, area sown cotton, area sown wheat, and area sown other crops). On the basis of highly significant statistical evidence, we preferred the estimates which we have discussed in the main body of this paper. But it is worth to mention that the estimates of TT and TU of other analysis did not differ in sign (see Appendix A3 Table A3.6, A3.7, and A3.8).

\subsubsection{Policy Implications}

Among the variables tested, we see government extension service broadcast via radio is the most promising policy option to encourage the adoption of improved agricultural technologies. This finding is in line with previous research findings (see for example Al-Hassan et al., 2011; Schreinemachers et al., 2016; Carvalho, 2017) and confirms that agricultural extension contacts promote the adoption of improved agricultural technologies. To aid diffusion of innovations among farmers, salient and practical information regarding agricultural improved technologies connotes the significance of institutional support for rural areas (Rogers, 1983). Consonant to that, this paper and recent literature shows the role of agricultural extension services on adoption, productivity enhancement, poverty alleviation, and particularly for food security in developing countries (Lee, 2005; Davis et al., 2012; Simtowe et al., 2016; Bilal and Barkmann, 2019). A focus on the

\footnotetext{
${ }^{11}$ For robustness, we separately executed a model for exclusive MBC adopters versus exclusive GC adopters $(N=222)$. We have found the similar evidence of the negative and significant value of TU and the positive and significant value of TT on food security status but slight difference in magnitude. That further validates and proved our hypothesis of positive food security effects of exclusive MBC adoption (see Table A3.11).
} 
improvement of government extension service broadcast via radio may also alleviate resource constraints of extension the services such as lack of extension staff (cf. Abbas et al., 2003; Aldosari et al., 2017).

Constructive policy implications can be drawn from the result that adoption is guided by comparative advantage. Exclusive adoption of MBC promotes food security among those smallholder farming households that actually adopted. What about non-adopters whose food security would have decreased if they had adopted. Should they be discouraged to switch to an exclusive use of MBC? Not necessarily. For example, off-farm income sources, if available, are more lucrative and help to alleviate capital constraints to adoption (Asfaw et al., 2012b; Ali et al., 2014; Simtowe et al., 2016). Likewise, farm mechanization also encourages adoption (Di Falco et al., 2011). From this perspective, an exclusive adoption of MBC appears as complementary to other smallholder farming inputs. Therefore, a policy that helps non-adopters to become mechanized and/or that increases off-farm income may facilitate adoption - with positive synergies on food security outcomes.

\subsection{Conclusion}

In this paper, we are mainly interested in the food security effects of the adoption of multinational brands crop protection products. The food security outcomes were assessed by the Household Food Insecurity Access Scale (HFIAS). This paper is confined to smallholder farming households of the cotton-wheat zone of the Punjab, Pakistan. We estimated an endogenous switching probit model with FIML to account observed and unobserved heterogeneity.

The treatment effects estimate suggests substantial positive effects of multinational brands crop protection products on food security. Smallholder farming households who actually adopted may have 22 percentage points less to food security if they did not adopt. In contrast, adoption may reduce food security by 19 percentage points to if non-adopters had adopted. This varying effect of adoption on food security indicates that the decision to adopt or not is guided by a realistic and rational assessment of the comparative advantage of adoption given the higher price of MBC (cf. Negash and Swinnen, 2013; Noltze et al., 2013; Krishna et al., 2017).

Based on FIML estimates, we conclude adoption is guided by the comparative advantage, we therefore, cannot suggest easy policy implications for enhancing food security of non-adopters. 
The negative effect of multinational brands crop protection products on food security status of nonadopters is an interesting finding of this research. Thus, similar negative effects of technology adoption on household welfare/income and food security for non-adopters in the recent past studies (cf. Negash and Swinnen, 2013; Noltze et al., 2013; Krishna et al., 2017) opens the door for future research to look into the matter deeply.

In particular, a policy that helps non-adopters to become mechanized and/or that increases off-farm income may foster adoption and have substantial positive synergies with food security outcomes. For example, among the variables tested, farmers listening to agricultural extension information via radio, off-farm income sources, seasonal labour, ownership of farm machinery, farm distance from the farm of village head, and farm distance from the main road were significantly pronounced for the adopters of multinational brands crop protection products. However, the study provides evidence regarding rural livelihood constraints (for example lack of farm machinery, less off-farm income sources, and low trend for listening of extension information via radio) vis-à-vis nonadopters that may have hint for negative adoption effects on their food security. For instance, multinational brands crop protection products are complementary to other input markets (for example farm machinery) and off-farm income helps cost to capital market access constraints.

In addition, the study provides positive evidence regarding institutional support such as extension information via radio on technology adoption. Positive effects of extension information and farmers training were shown for technology adoption (for example Larsen and Lilleør, 2014; Baloch and Thapa, 2016; Carvalho, 2017). However, lack of extension staff in developing countries context hinders the overall response to adoption (Abbas et al., 2003; Aldosari et al., 2017), hence, acquiring extension information via radio may reduce resource constraints.

This paper was solely confined to smallholder farming households, the inclusion of medium and large farming households will be an interesting case to investigate the causal effect of the adoption of multinational brands crop protection products on prevailing food insecurity at the country level. 


\section{Appendix A3}

\section{Table A3.1. Rotated component loading from PCA}

\begin{tabular}{|c|c|c|c|}
\hline HFIAS Questions & Comp1 & Comp 2 & Unexplained \\
\hline $\begin{array}{l}\text { Q1.In the month of shortage, did you have anxiety that you and any of } \\
\text { your household would not have enough food? }\end{array}$ & 0.47 & & 0.11 \\
\hline $\begin{array}{l}\text { Q2.In the month of shortage, were you and any of your households } \\
\text { remains unable to eat the specific types of foods you like due to } \\
\text { resource constraints? }\end{array}$ & 0.50 & & 0.06 \\
\hline $\begin{array}{l}\text { Q3.In the month of shortage did you and any of your households have } \\
\text { to eat limited types of foods because of resource constraints? }\end{array}$ & 0.48 & & 0.07 \\
\hline $\begin{array}{l}\text { Q4.In the month of shortage did you and any of your household have to } \\
\text { eat some types of foods that you and they really not preferred to eat due } \\
\text { to resource constraints to have other varieties of food? }\end{array}$ & 0.35 & & 0.13 \\
\hline $\begin{array}{l}\text { Q5.In the month of shortage did you and any of your household have to } \\
\text { eat a less quantity of meal than you felt you needed due to not enough } \\
\text { food? }\end{array}$ & 0.31 & & 0.13 \\
\hline $\begin{array}{l}\text { Q6.In the month of shortage did you and any of your household has to } \\
\text { eat fewer meals in a day due to not enough food? }\end{array}$ & & & 0.18 \\
\hline $\begin{array}{l}\text { Q7.In the month of shortage, were you and your household remains } \\
\text { foodless of any kind due to lack of resources to obtain food? }\end{array}$ & & 0.51 & 0.06 \\
\hline $\begin{array}{l}\text { Q8.In the month of shortage did you and any of your household goes to } \\
\text { sleep at night hungry due to not enough food? }\end{array}$ & & 0.54 & 0.03 \\
\hline $\begin{array}{l}\text { Q9.In the month of shortage did you and any of your household remains } \\
\text { hungry for full day and night due to not enough food? }\end{array}$ & & 0.54 & 0.05 \\
\hline
\end{tabular}

Table A3.2. Correlation of selection instruments with adoption and food security status

Correlation of adoption status with demographic attributes

Farm distance from the main road Farm distance from the farm of the village head

\begin{tabular}{lcc}
\hline Correlation & -0.11 & -0.13 \\
$p$-value & 0.05 & 0.02
\end{tabular}

Correlation of food security status with demographic attributes

Farm distance from the main road Farm distance from the farm of the village head

\begin{tabular}{lcc}
\hline Correlation & -0.04 & -0.02 \\
$p$-value & 0.44 & 0.63 \\
\hline
\end{tabular}

Table A3.3. The relevance and exogeneity conditions for selection instruments

\begin{tabular}{llr}
\hline Test & Null hypothesis & $p$-value \\
\hline Wu-Hausman test & Exclusion instruments are exogenous & $\mathrm{F}=0.43, \mathrm{p}=0.51$ \\
Wooldridge's score test & Exclusion instruments are exogenous & $\chi^{2}=0.46, \mathrm{p}=0.49$ \\
Anderson canonical correlation statistic & Underidentification & $\chi^{2}=7.33, \mathrm{p}=0.02$ \\
& Instruments uncorrelated with error terms & \\
Sargan statistic & (Overidentification) & $\chi^{2}=0.03, \mathrm{p}=0.85$ \\
Anderson-Rubin's test & Weak instrument robust test & $\chi^{2}=0.06, \mathrm{p}=0.96$
\end{tabular}


Table A3.4. Falsification approach to validate selection instrument

\begin{tabular}{lcc}
\hline & \multicolumn{2}{c}{\begin{tabular}{c} 
Dependent variable \\
\cline { 2 - 3 }
\end{tabular}} \\
\cline { 2 - 3 } Farm distance from the main road & adoption status & $\begin{array}{c}\text { food security status } \\
\text { (for non-adopters) }\end{array}$ \\
Farm distance from the farm of the village head & $-0.13^{*}(0.07)$ & $-0.23(0.17)$ \\
LR chi2 & $-0.15^{* *}(0.07)$ & $-0.07(0.12)$ \\
Wald test on selection instrument & $75.09^{* * *}$ & $30.87 * * *$ \\
Number of observations & $\chi^{2}=11.88^{* * *}$ & 132 \\
\hline Notes: Standard errors given in parentheses. The level of significance is $* * * \mathrm{p}<0.01, * * \mathrm{p}<0.05, * \mathrm{p}<0.1$ &
\end{tabular}

Table A3.5. Regression estimates of adoption of MBC from a probit model (main model)

\begin{tabular}{lcc}
\hline Adoption status $(1 / 0)$ & Coefficient & Standard error \\
\hline Total number of males in household & 0.05 & 0.05 \\
Total number of females in household & $-0.07^{*}$ & 0.04 \\
Marital status (yes=1; no=0) & -0.36 & 0.26 \\
Agri-extension-info via radio (yes=1; no=0) & $0.48^{* *}$ & 0.24 \\
Cell phone own (yes=1; no=0) & -0.34 & 0.34 \\
Number of milk animals & -0.03 & 0.05 \\
Off-farm income sources (yes=1; no=0) & $0.38^{* *}$ & 0.18 \\
Credit received (yes=1; no=0) & $-0.38^{* *}$ & 0.19 \\
Area in acres (1 hectare $=2.47$ acres) & 0.04 & 0.03 \\
Total seasonal labour male (agri-farming) & $0.06^{*}$ & 0.03 \\
Total seasonal labour female (agri-farming) & $0.07^{* *}$ & 0.03 \\
Farm machinery (yes=1; otherwise=0) & $0.54^{* *}$ & 0.22 \\
Region1 (if Vehari $=1 ;$ otherwise=0) & 0.22 & 0.22 \\
Region3 (if Pakpattan $=1$; otherwise=0) & $-0.45^{* *}$ & 0.22 \\
Farm distance from the village head $(\mathrm{km})$ & $-0.15^{* *}$ & 0.07 \\
Farm distance from the main road $(\mathrm{km})$ & $-0.13^{*}$ & 0.07 \\
Log pseudo likelihood & -152.85 & \\
LR $\chi^{2}$ & $75.09^{* * *}$ & 275 \\
Number of observations & & \\
\hline Notes: The level of significance is $* * * p<0.01, * * p<0.05, * p<0.1$ & &
\end{tabular}


Table A3.6. Estimates of the endogenous switching probit model (second model)

\begin{tabular}{|c|c|c|c|}
\hline & & Foo & status \\
\hline & $\begin{array}{c}\text { Adoption status } \\
(1 / 0)\end{array}$ & $\begin{array}{c}\text { Adopter } \\
\text { Households }\end{array}$ & $\begin{array}{c}\text { Non-adopter } \\
\text { households }\end{array}$ \\
\hline Age in years & 0.00 & 0.01 & -0.00 \\
\hline & $(0.00)$ & $(0.00)$ & $(0.01)$ \\
\hline Total number of adult family labour & 0.16 & -0.00 & -0.21 \\
\hline & $(0.12)$ & $(0.13)$ & $(0.19)$ \\
\hline Hired labour & 0.46 & 0.19 & $1.22 * *$ \\
\hline & $(0.31)$ & $(0.34)$ & $(0.56)$ \\
\hline Total number of females in $\mathrm{Hh}$ & $-0.07 *$ & $-0.08 *$ & 0.05 \\
\hline & $(0.04)$ & $(0.05)$ & $(0.06)$ \\
\hline Number of males involve in off-farm income & 0.11 & $-0.00 *$ & $-0.21 * * *$ \\
\hline & $(0.11)$ & $(0.13)$ & $(0.18)$ \\
\hline Agri-info via radio & $0.43 * *$ & 0.13 & $1.06^{* * *}$ \\
\hline & $(0.19)$ & $(0.20)$ & $(0.39)$ \\
\hline Access to credit & -0.03 & $-0.51 * *$ & -0.08 \\
\hline & $(0.17)$ & $(0.21)$ & $(0.31)$ \\
\hline Capital own & $0.58 * * *$ & $1.04 * * *$ & $0.59 *$ \\
\hline & $(0.21)$ & $(0.27)$ & $(0.33)$ \\
\hline Regional dummy 1 & $0.78 * * *$ & $1.30 * * *$ & 0.32 \\
\hline & $(0.23)$ & $(0.29)$ & $(0.47)$ \\
\hline Regional dummy 2 & 0.31 & 0.10 & $1.07 * *$ \\
\hline & $(0.26)$ & $(0.30)$ & $(0.48)$ \\
\hline Area sown wheat (acres) & -0.01 & -0.01 & 0.09 \\
\hline & $(0.07)$ & $(0.09)$ & $(0.15)$ \\
\hline Area sown cotton (acres) & $0.19 * *$ & $0.27 * * *$ & -0.08 \\
\hline & $(0.08)$ & $(0.09)$ & $(0.13)$ \\
\hline Area sown other crops (acres) & -0.07 & 0.04 & 0.06 \\
\hline & $(0.06)$ & $(0.07)$ & $(0.12)$ \\
\hline Farm distance from the village head $(\mathrm{km})$ & $-0.14 * *$ & & \\
\hline & $(0.06)$ & & \\
\hline Farm distance from the main road $(\mathrm{km})$ & $-0.14^{* *}$ & & \\
\hline & $(0.07)$ & & \\
\hline$\rho_{F S} / \rho_{N F S}$ & & $0.99 * * *$ & -0.25 \\
\hline & & $(0.00)$ & $(0.41)$ \\
\hline Wald test of indep. eqns. chi2(2) & & & $8.98 * *$ \\
\hline Log pseudo likelihood & & & -285.82 \\
\hline
\end{tabular}


Table A3.7. Treatment effects of MBC adoption on food security status (second model)

\begin{tabular}{llll}
\hline \multirow{2}{*}{ Sub-samples } & \multicolumn{2}{c}{ Decision stage } & \\
\cline { 2 - 3 } Adopter smallholder farming households & To Adopt & Not to Adopt & Treatment Effects \\
\hline Non-adopter smallholder farming households & 0.32 & 0.10 & TT $=0.22^{* * *}$ \\
& $(0.01)$ & $(0.00)$ & $(0.01)$ \\
Heterogeneity effects & 0.20 & 0.40 & TU $=-0.20^{* * *}$ \\
& $(0.00)$ & $(0.01)$ & $(0.01)$ \\
& $\mathrm{BH} 1=0.12$ & $\mathrm{BH} 2=-0.30$ & $\mathrm{TH}=0.42^{* * *}$ \\
\hline
\end{tabular}

Notes: TT stands for the effect of the treatment on the treated, TU for the effect of the treatment on the untreated, BH1 and BH2 for base heterogeneity for the smallholder farming households those adopted (MBC) and those did not adopt, and TH for transitional heterogeneity. Standard errors are in parentheses, the level of significance is $* * * p<0.01, * * p<0.05, * p<0.1$

Table A3.8. Regression estimates of adoption of MBC from a probit model (second model)

Adoption status $(1 / 0)$

Age in years

Total number of adult family labour

Hired labour

Total number of females in $\mathrm{Hh}$

Number of males involved in off-farm income

Agri-info via radio

Access to credit

Capital own

Regional dummy 1

Regional dummy 2

Area sown wheat (acres)

Area sown cotton (acres)

Area sown other crops (acres)

Farm distance from the village head $(\mathrm{km})$

Farm distance from the main road $(\mathrm{km})$

Constant

Log pseudo likelihood

Wald $\chi^{2}$

Number of observations

Notes: The level of significance is $* * * \mathrm{p}<0.01, * * \mathrm{p}<0.05, * \mathrm{p}<0.1$
Coefficient

Robust standard error

0.00

0.00

0.15

0.12

0.41

0.30

$-0.07 * *$

0.03

0.11

0.11

$0.46^{* *}$

0.19

$-0.05$

0.17

$0.62 * * *$

0.20

$0.80 * * *$

0.23

0.27

0.26

$-0.04$

0.08

$0.19 * *$

0.08

$-0.07$

0.06

$-0.11 *$

0.06

$-0.12 *$

0.07

$-1.03 * *$

0.47

$-161.73$

$52.78 * * *$

275 
Table A3.9. Treatment effects of MBC adoption on food security status (reduced model excluding all potentially endogenous variables)

\begin{tabular}{llll}
\hline \multirow{2}{*}{ Sub-samples } & \multicolumn{2}{c}{ Decision stage } & \\
\cline { 2 - 3 } & To Adopt & Not to Adopt & Treatment Effects \\
\hline Adopter smallholder farming households & 0.31 & 0.09 & TT $=0.22^{* * *}$ \\
Non-adopter smallholder farming households & $(0.01)$ & $(0.00)$ & $(0.01)$ \\
Heterogeneity effects & 0.21 & 0.39 & TU $=-0.18^{* * *}$ \\
& $(0.00)$ & $(0.01)$ & $(0.01)$ \\
& BH1 $=0.10$ & BH2 $=-0.30$ & TH $=0.40^{* * *}$ \\
\hline
\end{tabular}

Notes: TT stands for the effect of the treatment on the treated, TU for the effect of the treatment on the untreated, $\mathrm{BH} 1$ and $\mathrm{BH} 2$ for base heterogeneity for the smallholder farming households those adopted (MBC) and those did not adopt, and TH for transitional heterogeneity. Standard errors are in parentheses, the level of significance is $* * * p<0.01, * * p<0.05, * p<0.1$

Table A3.10. Estimates of the endogenous switching probit model (reduced model excluding all potentially endogenous variables)

\begin{tabular}{|c|c|c|c|}
\hline & \multicolumn{3}{|c|}{ Food security status } \\
\hline & $\begin{array}{l}\text { Adoption status } \\
\qquad(1 / 0)\end{array}$ & $\begin{array}{l}\text { Adopter } \\
\text { households }\end{array}$ & $\begin{array}{l}\text { Non-adopter } \\
\text { households }\end{array}$ \\
\hline Total number of males in household & $0.09 * *(0.04)$ & $0.07(0.05)$ & $0.01(0.07)$ \\
\hline Total number of females in household & $-0.06(0.04)$ & $-0.01(0.05)$ & $0.04(0.05)$ \\
\hline Marital status (yes $=1 ;$ no $=0$ ) & $-0.33(0.24)$ & $-0.33(0.26)$ & $-0.37(0.39)$ \\
\hline Agri-extension-info via radio (yes $=1 ;$ no $=0$ ) & $0.46 *(0.25)$ & $0.11(0.28)$ & $0.57(0.48)$ \\
\hline Cell phone own (yes=1; no=0) & $-0.41(0.35)$ & $-0.27(0.35)$ & $0.51(0.60)$ \\
\hline Area in acres $(1$ hectare $=2.47$ acres $)$ & $0.03(0.03)$ & $0.06(0.04)$ & $0.01(0.07)$ \\
\hline Total seasonal labour male (agri-farming) & $0.09 * *(0.03)$ & $0.12 * * *(0.04)$ & $0.04(0.07)$ \\
\hline Total seasonal labour female (agri-farming) & $0.07 * *(0.02)$ & $0.05 *(0.03)$ & $0.00(0.06)$ \\
\hline Region1 (if Vehari $=1$; otherwise $=0$ ) & $0.25(0.22)$ & $0.65 * * *(0.25)$ & $-0.79 * *(0.36)$ \\
\hline Region3 (if Pakpattan =1; otherwise=0) & $-0.51 * *(0.21)$ & $-0.42 *(0.24)$ & $-0.54 *(0.33)$ \\
\hline Farm distance from the village head (km) & $-0.18 * * *(0.06)$ & & \\
\hline Farm distance from the main road $(\mathrm{km})$ & $-0.18 * * *(0.06)$ & & \\
\hline Log pseudo likelihood & -295.75 & & \\
\hline Wald $\chi^{2}(12)$ & $61.54 * * *$ & & \\
\hline Errors correlation coefficients & & $\rho_{F S} 0.90^{* * *}$ & $\rho_{N F S}-0.46$ \\
\hline Wald test of independent equations $\chi^{2}(2)$ & $4.72 *$ & & \\
\hline
\end{tabular}

Notes: Robust standard errors are in parentheses, the level of significance is $* * * \mathrm{p}<0.01, * * \mathrm{p}<0.05, * \mathrm{p}<0.1 . \rho_{\mathrm{FS}}$ indicates the correlation coefficient for adopters and food secure smallholder farming households and $\rho_{\mathrm{NFS}}$ indicates the errors correlation coefficient for adopters and food insecure smallholder farming households. 
Table A3. 11. Treatment effects of exclusive MBC adoption versus exclusive GC adoption on food security status $(N=222)$

\begin{tabular}{llll}
\hline \multirow{2}{*}{ Sub-samples } & \multicolumn{2}{c}{ Decision stage } & \\
\cline { 2 - 3 } Adopter smallholder farming households & To Adopt & Not to Adopt & Treatment Effects \\
\hline \multirow{2}{*}{ Non-adopter smallholder farming households } & 0.39 & 0.06 & TT $=0.33^{* * *}$ \\
& $(0.01)$ & $(0.00)$ & $(0.02)$ \\
Heterogeneity effects & 0.25 & 0.29 & TU $=-0.04 * * *$ \\
& $(0.01)$ & $(0.01)$ & $(0.02)$ \\
& $\mathrm{BH} 1=0.14$ & $\mathrm{BH} 2=-0.23$ & $\mathrm{TH}=0.37^{* * *}$ \\
& $(0.02)$ & $(0.01)$ & $(0.02)$ \\
\hline
\end{tabular}

Notes: TT stands for the effect of the treatment on the treated, TU for the effect of the treatment on the untreated, BH1 for base heterogeneity for the smallholder farming households those adopted (MBC) and BH2 for those adopted (GC), and TH for transitional heterogeneity. Standard errors are in parentheses, the level of significance is $* * * \mathrm{p}<0.01, * * \mathrm{p}<0.05, * \mathrm{p}<0.1$ 


\section{General conclusion and policy options}

\subsection{Background and conceptual framework}

With this dissertation, we were aiming at filling the persisting knowledge gap on the adoption of multinational brands crop protection products (MBC) versus generic crop protection products (GC) (for example fungicides, insecticides, and herbicides). Additionally, we focused the food security effects of the adoption of MBC for the smallholder farming household of the cotton-wheat zone Punjab, Pakistan. Primarily, we contribute to the present body of knowledge by twofold: in second chapter, we determine what influences the smallholder farming households to adopt improved quality agrochemical inputs and in third chapter, we determine the food security effects of the exclusive adoption of $\mathrm{MBC}$ versus non-adoption.

The second chapter encompasses the pros and cons of using agrochemical inputs, the adoption of existing agricultural technologies in developing countries and the justification to focus on the improved quality agrochemical inputs. It also comprises the Pakistani official registration procedure for the categorization of available agrochemical inputs in terms of quality in the agricultural mainland of the country. For better understanding of the registration procedure, we assign the title type A to given agrochemical inputs if it is imported from an OECD (Organization for Economic Cooperation and Development) listed country and China (improved quality agrochemical inputs). The Type B agrochemical inputs follows field trails before marketing permission (intermediate quality), and type $\mathrm{C}$ agrochemical inputs only involve sample laboratory examination before marketing permission (base quality). We particularly in this chapter interested to see the influence of farm and farmer capital variables of the smallholder farming households on exclusive adoption of improved quality agrochemical inputs.

Before performing the empirical analysis, we had initially observed that there is little proportion of smallholder farming households who use a mix of all available quality of agrochemical inputs. Based on our sample, we observed six different options of adoption of agrochemical inputs by the smallholder farming households (see Table 2.2 chapter 2). Due to highly infrequent proportion of mix use options of adoption of agrochemical inputs in the total sample, we integrated all mix users and termed them as intermediate users. Finally, we left with three popular options of adoptions by 
the smallholder farming households, which we subsequently used in empirical analysis (see Table 2.3 chapter 2 ). The first option consists of type $A$ exclusively improved quality agrochemical inputs adopters, second option consists of intermediate users of all type A type C, and type B (intermediate adopters), and the third option consists type $C$ (exclusively base quality adopters). Due to the ordinal nature of the dependent variable, we employ ordered probit models.

In the third chapter, we exclusively segregated the smallholder farming households into two groups: adopters (exclusive $\mathrm{MBC}$ ) and non-adopters (GC/otherwise). We use an internationally accepted module to measure food security status of farming households in context to developing countries of Asia and Africa. For the very first time, the Household Food Insecurity Access Scale (HFIAS) is used to measure food security status in context agricultural farming community of Pakistan (Coates et al., 2007). Subsequently, we assigned the smallholder farming households into two groups: exclusive food secures households and food insecure households and assigned discrete values depend upon the nature of group they belong respectively. Due to discrete nature of two sets of the dependent variable (see Table 3.1 chapter 3 ), we employed an endogenous switching probit model. The main intuition behind to employed this model is to address the methodological challenges of non-experimental studies. For example, the main purpose of using the model is that it controls for potential self-selection bias and account the potential heterogeneity. Additionally, we also considered selection instruments for better identification of the model, and the consideration of selection instruments is guided by economic theory and empirical research evidence. We considered demographic variables; farmers farm distance from the main road and farmers' farm distance from the farm of the village head. The relevance and exogeneity of selection instruments are checked by exclusion restriction approach by Di Falco et al. (2010) and with further statistical tests (e.g., Sargan test for overidentification and Anderson canonical correlation statistic for underidentification) employed for the robustness of inclusion of selection instruments.

\subsection{Main findings}

With the second chapter, we have analysed the potential role of farm and farmer capital in the exclusive adoption of improved quality agrochemical inputs. In doing so, on one hand, the subjective opinions of the farmers about quality of agrochemical inputs reported with $51 \%$ for improved quality, $23 \%$ reported low quality, and $26 \%$ reported poor quality respectively. It is the relevant finding which supports past research and indicates the occurrence and prevalence of low 
to poor quality agrochemical inputs in the agricultural mainland of Pakistan (Khan et al., 2002; Khooharo et al., 2008; Nafees et al., 2008; Khan et al., 2012; Hashmi, 2016). On the other hand, we find statistically significant evidence of several farming and farm capital variables (cotton crop area, farm machinery, no-tillage farming, and adoption in the neighbourhood) stimulate adoption of improved quality agrochemical inputs. Likewise, several farmer capital variables (age, education, off-farm income, agricultural extension services, and source of agricultural credit) stimulate adoption of improved quality agrochemical inputs.

Furthermore, agricultural extension service visits enhance the probability with $10 \%$ increase in the adoption of improved quality agrochemical inputs. This is important finding and explicitly the result of the need which supports theory of diffusion of innovation, which signifies the role of agricultural extension services to help farmers to diversify farmers' knowledge and experience about innovative technologies. In nutshell, we find robust and rationale results, which in principle show that the farm and farmer capital variables which determine the initial adoption of agrochemical inputs exhibit the similar relationship for the adoption of improved quality agrochemical inputs.

The third chapter of this dissertation focuses on the food security effect of the exclusive adoption of MBC. We assume that adopters and non-adopters would adopt depending upon their nuance about $\mathrm{MBC}$ and their socio-economics characteristics. At first glance, the socio-economic characteristics, in particular, the frequent reliance on the electronic media by the farmers, especially listening of the agricultural extension information via radio indicate positive and significant association with the adoption of MBC. Second, the full information maximum likelihood (FIML) estimates indicate that adoption is guided by comparative advantage (see Table 3.3 chapter 3 ). This suggests that adopters have higher average values of food security outcomes than non-adopters, and non-adopters also have higher average values of food security outcomes from non-adoption.

On top of that, our main hypothesis about the food security gains by the adoption of MBC to visible extent is supported by our results. Our results confirm that the treatment effect (food security) on treated (adopters) is positive and significant. This suggests that adoption to MBC would positively contribute to the food security of adopters ( +22 percentage points) and their decision to opt for MBC presumably robust and rational. Surprisingly, the negative significant value of treatment effects on untreated (-19 percentage points) suggest that adoption to $\mathrm{MBC}$ would not positively 
contribute to the food security of non-adopters. The negative effect of MBC on food security status of non-adopters is the most striking part of this research which may suggest their decision not to opt for exclusive adoption of MBC presumably robust and rational as well. This finding supports the recent past research findings regarding technology adoption, wherein, they proclaimed negative effect of technology adoption on household welfare/income and food security for non-adopters (cf. Negash and Swinnen, 2013; Noltze et al., 2013; Krishna et al., 2017). Lastly, we find the positive significant results of the potential heterogeneity $(+0.41 ; p$-value $<1 \%)$ in the sample. This may depict that heterogeneity effects are significantly higher for those smallholder farming households that actually did adopt relative to those that did not adopt.

\subsection{Implications for farming households and potential policy options}

Knowing the circumstances that the substantive farming community of Pakistan belongs to small farmers' community and the illiterate farmers can benefit from extension field staff visits and farmers field school for the latest agricultural technologies and methods (Saqib and Tachibana, 2014; Larsen and Lilleør, 2014; Baloch and Thapa, 2016). For that reason, we see agricultural extension services in the limelight for the most promising policy options. Our results showed that agricultural extension service visits contribute positively to the adoption of MBC. Thus, it is important to make sure the effective and active part of government agricultural extension service in rural villages. Similar policy options can be extracted from the farmers' frequent reliance on the electronic media, especially listening of the agricultural extension information via radio (cf. Manda and Wozniak, 2015). It entangles the fundamental role of government extension service as an easiest way to disseminate information on latest technologies, which may aid to dispel their constraint of lack of extension staff (Abbas et al., 2003; Aldosari et al., 2017). Therefore, we suggest that the country's federal and provincial agricultural administrations focus on effective outreach of extension service in rural villages.

Based on FIML estimates, we conclude adoption is guided by the comparative advantage. It illustrates that adoption of $\mathrm{MBC}$ would contribute positively and significantly in the food security status of adopters. However, negative effects of technology adoption on household welfare/income and food security in this paper and in the recent past studies (cf. Negash and Swinnen, 2013; Noltze et al., 2013; Krishna et al., 2017) for non-adopters clearly deserve the prime attention of agricultural policy makers to take up the issue for amendments. Hence, the comparative advantage of using 
multinational brands crop protection products between adopters and non-adopters do not preclude that some of the characteristics of non-adopter's smallholder farming households could not be changed.

For agriculture and development policy scenario and with the view of sustainable intensification based on these results, we see provision of off-farm income sources pronounced to mitigate liquidity constraints, support regarding mechanised farming, and increased access to extension service illustrate the pathway leads to incorporation of multinational technologies among nonadopters. Therefore, effective policy which facilitates smallholders to incorporate proven multinational technologies in their production system to overcome existing food insecurity is a dire need of time.

\subsection{Limitations and future research prospects and endeavours}

We hereby acknowledge the limitations of the research presented in this dissertation. This research was confined solely to smallholder farming households, who are characterized on the basis of their landholdings if equal or less than 5 acres [ $2.02 \mathrm{ha}$. The inclusion of medium farming households (landholdings if equal or less than 25 acres [ 10.11 ha] acres but more than 5 acers [ 2.02 ha]) and large farmers (landholdings if more than 25 acers [ 10.11 ha]) will be an interesting case to investigate the causal effect of the adoption of $\mathrm{MBC}$ on prevailing food insecurity at the country level.

Secondly, this dissertation focused only one agro-ecological zone of Punjab province i.e., cottonwheat Punjab, but the other agro-ecological zones, i.e., mixed cropping Punjab, rice-wheat Punjab, rain-fed Punjab, and low-intensity Punjab were not covered. Additionally, though, the number of respondents used in this dissertation is fairly match with previous research regarding cotton-wheat zone of Punjab, Pakistan (Abedullah et al., 2015; Battese et al., 2017) but relatively less in contrast to similar farming households globally (Qaim and Kouser, 2013; Karimov, 2014; Makombe et al., 2017).

On top of that, the societal hindrance to access interviewing the females' household head was not controlled, but can be address if future research will hire female assistants to interview the household head in case of female govern households in rural Pakistan. Lastly, considering the aforementioned potential heterogeneity between adopters and non-adopters, it would be interesting 
to understand the potential heterogeneity in research and development sectors of generic crop protection products firms of Pakistan versus multinational brands crop protection products to seek for alleviating food insecurity issue. 


\section{References}

Aakvik, A., Heckman, J. J. and Vytlacil, E. J. (2005). Estimating treatment effects for discrete outcomes when responses to treatment vary: An application to Norwegian vocational rehabilitation programs. Journal of Econometrics, 125(1-2), 15-51. https://doi.org/10.1016/j.jeconom.2004.04.002

Abbas, M., Sheikh, A. D., Muhammad, S. and Ashfaq, M. (2003). Role of electronic media in the adoption of agricultural technologies by farmers in the central Punjab-Pakistan. International Journal of Agriculture \& Biology, 5(1), 22-25.

Abdulai, A. and Huffman, W. (2014). The adoption and impact of soil and water conservation technology: An endogenous switching regression application. Land Economics, 90(1), 26-43. https://doi.org/10.3368/le.90.1.26

Abdullah, A. (2010). An analysis of Bt cotton cultivation in Punjab, Pakistan using the agriculture decision support system (ADSS). AgBioForum, 13(3), 274-287.

Abedullah, Kouser, S. and Qaim, M. (2015). Bt cotton, pesticide use and environmental efficiency in Pakistan. Journal of Agricultural Economics, 66(1), 66-86. https://doi.org/10.1111/14779552.12072

Aga, A. (2019). The marketing of corporate agrichemicals in Western India: Theorizing graded informality. The Journal of Peasant Studies, 46(7), 1458-1476. https://doi.org/10.1080/03066150.2018.1534833

Ahmad, T. I., Zeeshan, M., Syed, B. A. Z. and Maryyum, N. (2016). Caring the primary caregivers-Determinants of farmwomen's health: A view from rural Punjab-Pakistan. Pakistan Journal of Humanities and Social Sciences, 4(1), 17-36.

Aktar, W., Sengupta, D. and Chowdhury, A. (2009). Impact of pesticides use in agriculture: Their benefits and hazards. Interdisciplinary Toxicology, 2(1), 1-12. https://doi.org/10.2478/v10102-009-0001-7

Alam, M. Z., Haque, Md. M., Islam, Md. S., Hossain, E., Hasan, S. B., Hasan, S. B. and Hossain, Md. S. (2016). Comparative study of integrated pest management and farmers practices on sustainable environment in the rice ecosystem. International Journal of Zoology, 1-12. https://doi.org/10.1155/2016/7286040

Aldosari, F., Al Shunaifi, M. S., Ullah, M. A., Muddassir, M. and Noor, M. A. (2019). Farmers' perceptions regarding the use of Information and Communication Technology (ICT) in 
Khyber Pakhtunkhwa, Northern Pakistan. Journal of the Saudi Society of Agricultural Sciences, 18(2), 211-217. https://doi.org/10.1016/j.jssas.2017.05.004

Alene, A. D. and Manyong, V. M. (2007). The effects of education on agricultural productivity under traditional and improved technology in northern Nigeria: An endogenous switching regression analysis. Empirical Economics, 32(1), 141-159. https://doi.org/10.1007/s00181006-0076-3

Al-Hassan, S., Andani, A. and Abdul-Malik, A. (2011). The role of community radio in livelihood improvement: the case of Simli radio. Field Actions Science Reports, 7.

Ali, A. and Sharif, M. (2012). Impact of farmer field schools on adoption of integrated pest management practices among cotton farmers in Pakistan. Journal of the Asia Pacific Economy, 17(3), 498-513. https://doi.org/10.1080/13547860.2012.694706

Ali, D. A., Deininger, K. and Duponchel, M. (2014). Credit constraints and agricultural productivity: evidence from rural Rwanda. The Journal of Development Studies, 50(5), 649665. https://doi.org/10.1080/00220388.2014.887687

Ali, H., Abid, S. A., Ahmad, S., Sarwar, N., Arooj, M., Mahmood, A. and Shahzad, A. N. (2013). Impact of integrated weed management on flat-sown cotton (Gossypiumhirsutum L.). The Journal of Animal and Plant Sciences, 23(4), 1185-1192.

Alston, J. M. (2010). The benefits from agricultural research and development, innovation, and productivity growth. Food, Agriculture and Fisheries Papers, No. 31, OECD Publishing, Paris. http://dx.doi.org/10.1787/5km91nfsnkwg-en

Anandajayasekeram, P. (2011). The role of agricultural R\&D within the agricultural innovation systems framework. Agricultural R\&D - Investing in Africa's future: Analyzing Trends, Challenges, and Opportunities, Accra, Ghana: ASTI, FARA. Conference Working Paper 6. Pp. 33.

Antle, J. M. and Pingali, P. L. (1994). Pesticides, productivity, and farmer health: A Philippine case study. American Journal of Agricultural Economics, 76, 418-430.

Asfaw, S., Kassie, M., Simtowe, F. and Lipper, L. (2012a). Poverty reduction effects of agricultural technology adoption: A micro-evidence from Rural Tanzania. Journal of Development Studies, 48(9), 1288-1305. https://doi.org/10.1080/00220388.2012.671475

Asfaw, S., Shiferaw, B., Simtowe, F. and Lipper, L. (2012b). Impact of modern agricultural technologies on smallholder welfare: Evidence from Tanzania and Ethiopia. Food Policy, 37(3), 283-295. https://doi.org/10.1016/j.foodpol.2012.02.013 
Ashraf, S., Khan, G. A., Ali, S. and Iftikhar, M. (2015). Socio-economic determinants of the awareness and adoption of citrus production practices in Pakistan. Ciência Rural, 45(9), 17011706. https://doi.org/10.1590/0103-8478cr20131227

Ayandiji, A. and Olofinsao, O. T. (2015). Socio-economic factors affecting adoption of farm mechanization by cassava farmers in Ondo State, Nigeria. Journal of Environmental Science, Toxicology and Food Technology, 9(3), 39-45. https://doi.org/doi: 10.9790/2402-09313945

Azam, A. and Shafique, M. (2017). Agriculture in Pakistan and its Impact on Economy-A Review. International Journal of Advanced Science and Technology, 103, 47-60. https://doi.org/10.14257/ijast.2017.103.05

Azizullah, A., Khattak, M. N. K., Richter, P. and Häder, D. P. (2011). Water pollution in Pakistan and its impact on public health-A review. Environment International, 37(2), 479-497.

Baloch, M. A. and Thapa, G. B. (2018). The effect of agricultural extension services: Date farmers' case in Balochistan, Pakistan. Journal of the Saudi Society of Agricultural Sciences, 17(3), 282-289. https://doi.org/10.1016/j.jssas.2016.05.007

Barbera, V., Poma, I., Gristina, L., Novara, A. and Egli, M. (2012). Long-term cropping systems and tillage management effects on soil organic carbon stock and steady state level of C sequestration rates in a semiarid environment. Land Degradation \& Development, 23(1), 8291. https://doi.org/10.1002/ldr.1055

Bashir, M. K. and Schilizzi, S. (2013). Determinants of rural household food security: A comparative analysis of African and Asian studies: Determinants of rural household food security. Journal of the Science of Food and Agriculture, 93(6), 1251-1258. https://doi.org/10.1002/jsfa.6038

Battese, G. E., Nazli, H. and Smale, M. (2017). Factors influencing the productivity and efficiency of wheat farmers in Punjab, Pakistan. Journal of Agribusiness in Developing and Emerging Economies, 7(2), 82-98. https://doi.org/10.1108/JADEE-12-2013-0042

Beintema, N. M., Malik, W., Sharif, M., Stads, G.-J. and Mustafa, U. (2007). Agricultural research and development in Pakistan: Policy, investments, and institutional profile. ASTI Country Report.

Bellemare, M. F. (2010). As you sow, so shall you reap: The welfare impacts of contract farming. Munich Personal RePEc Archive (MPRA) Paper No. 23638. 
Bilal, M. and Barkmann, J. (2018). Determinants of adoption of sustainable intensificationenhancing technologies: Evidence from the cotton-wheat Zone in Pakistan. Tielkes, E. (Ed.). Tropentag 2018. Global Food Security and Food Safety: The Role of Universities. Pp. 30.

Bilal, M. and Barkmann, J. (2019). Farm and farmer capital foster adoption of improved quality agro-chemical inputs in the cotton-wheat zone of the Punjab, Pakistan. Journal of Agriculture and Rural Development in Tropics and Subtropics, 120(2), 229-240. https://doi.org/doi.org/10.17170/kobra-20191217881

Bilal, M., Brümmer, B. and Barkmann, J. (in prep.). Food security effects of improved crop protection products: Evidence from cotton-wheat zone Pakistan.

Bilal, M., Shakoor, U., Nasir, A. and Raza, Q. (2015). Revisiting snags for obtaining agricultural credit in Pakistan: the case of small farmers. International Journal of Scientific Footprints, 3(1), 4 1-51.

Bishwajit, G. (2014). Promoting agricultural research and development to strengthen food security in South Asia. International Journal of Agronomy, 1-6. https://doi.org/10.1155/2014/589809

Bonabana-Wabbi, J. (2002). Assessing factors affecting adoption of agricultural technologies: The case of Integrated Pest Management (IPM) in Kumi District, Eastern Uganda. MSc. thesis Virginia Polytechnic Institute and State University, United States. 146.

Brookes, G., Taheripour, F. and Tyner, W. E. (2017). The contribution of glyphosate to agriculture and potential impact of restrictions on use at the global level. GM Crops \& Food, 8(4), 216228. https://doi.org/10.1080/21645698.2017.1390637

Carvalho, F. P. (2017). Pesticides, environment, and food safety. Food and Energy Security, 6(2), 48-60. https://doi.org/10.1002/fes3.108

Chinnakali, P., Upadhyay, R. P., Shokeen, D., Singh, K., Kaur, M., Singh, A. K., Goswami, A., Yadav, K. and Pandav, C. S. (2014). Prevalence of household-level food insecurity and its determinants in an urban resettlement colony in North India.

Journal of Health, Population and Nutrition, 32(2), 227-236.

Coates, J., Swindale, A. and Bilinsky, P. (2007). Household Food Insecurity Access Scale (HFIAS) for measurement of food access: Indicator guide, version 3. https://doi.org/10.1037/e576842013-001

Danne, M., Musshoff, O. and Schulte, M. (2019). Analysing the importance of glyphosate as part of agricultural strategies: A discrete choice experiment. Land Use Policy, 86, 189-207. 
https://doi.org/10.1016/j.landusepol.2019.04.023

Davis, K., Nkonya, E., Kato, E., Mekonnen, D. A., Odendo, M., Miiro, R. and Nkuba, J. (2012). Impact of farmer field schools on agricultural productivity and poverty in East Africa. World Development, 40(2), 402-413. https://doi.org/10.1016/j.worlddev.2011.05.019

Dedehouanou, S. F. A., Araar, A., Ousseini, A., Harouna, A. L. and Jabir, M. (2018). Spillovers from off-farm self-employment opportunities in rural Niger. World Development, 105, 428442. https://doi.org/10.1016/j.worlddev.2017.12.005

Dhaliwal, G. S., Jindal, V. and Mohindru, B. (2015). Crop losses due to insect pests: Global and Indian scenario. Indian Journal of Entomology, 77(2), 165. https://doi.org/10.5958/09748172.2015.00033.4

Di Falco, S., Veronesi, M. and Yesuf, M. (2011). Does adaptation to climate change provide food security? A micro-perspective from Ethiopia. American Journal of Agricultural Economics, 93(3), 829-846. https://doi.org/doi: 10.1093/ajae/aar006

Doss, C. R. (2003). Understanding farm-level technology adoption: lessons learned from CIMMYT'S micro surveys in Eastern Africa. International Maize and Wheat Improvement Centre (CIMMYT) Economics Working Paper, 03-07. Mexico.

Doss, C. R. and Morris, M. L. (2000). How does gender affect the adoption of agricultural innovations? The case of improved maize technology in Ghana. Agricultural Economics, 25, 27-39.

Elias, A., Nohmi, M., Yasunobu, K. and Ishida, A. (2013). Effect of agricultural extension program on smallholders' farm productivity: Evidence from three peasant associations in the highlands of Ethiopia. Journal of Agricultural Science, 5(8), 163-181.

https://doi.org/doi:10.5539/jas.v5n8p163

FAO. (2017). Food and Agriculture Organization.

Retrieved from http://www.fao.org/economic/ess/ess-fs/en/

FAO. (2019). Food and Agriculture Organization.

Retrieved from http://www.fao.org/faostat/en/\#data/QC

FAO and WHO. (2016). International code of conduct on pesticide management guidelines on highly hazardous pesticides. Retrieved from http://www.fao.org/3/a-i5566e.pdf

Fernandez-Cornejo, J. (2012). Conservation tillage, herbicide use, and genetically engineered crops in the United States: The case of soybeans. AgBioForum, 15(3), 231-241. 
Fuglie, K. O. and Bosch, D. J. (1995). Economic and environmental implications of soil nitrogen testing: A switching-regression analysis. American Journal of Agricultural Economics, 77(4), 891-900.

Garnett, T. and Godfray, H. C. J. (2012). Sustainable intensification in agriculture. navigating a course through competing food system priorities. Food Climate Research Network and the Oxford Martin Programme on the Future of Food, University of Oxford, UK.

Gebreyesus, S. H., Lunde, T., Mariam, D. H., Woldehanna, T. and Lindtjørn, B. (2015). Is the adapted Household Food Insecurity Access Scale (HFIAS) developed internationally to measure food insecurity valid in urban and rural households of Ethiopia? BMC Nutrition, 1(1), 2. https://doi.org/10.1186/2055-0928-1-2

GFSI. (2019). Global Food Security Index.

Retrieved from http://foodsecurityindex.eiu.com/Index

GHI. (2019). Global Hunger Index. Retrieved from https://www.globalhungerindex.org/results/ Greene, W. H. (2003). Econometric analysis (5th ed). Prentice Hall.

Hailu, B. K., Abrha, B. K. and Weldegiorgis, K. A. (2014). Adoption and impact of agricultural technologies on farm income: evidence from Southern Tigray, Northern Ethiopia. International Journal of Food and Agricultural Economics, 2(4), 91-106.

Hajirostamlo, B., Mirsaeedghazi, N., Arefnia, M., Ali, M. and Fard, E. A. (2015). The role of research and development in agriculture and its dependent concepts in agriculture. Asian Journal of Applied Science and Engineering, 4(1), 5.

Hameed, R. A., Ajum, S. and Afzal, M. N. (2017). Effect of glyphosate and paraquat herbicides on weed control and productivity of cotton. Cercetari Agronomice in Moldova, 50(2), 51-56. https://doi.org/10.1515/cerce-2017-0014

Handschuch, C. and Wollni, M. (2016). Improved production systems for traditional food crops: The case of finger millet in western Kenya. Plant Pathology, 8(4), 783-797.

Hänke, H. and Barkmann, J. (2017). Insurance function of livestock, farmers coping capacity with crop failure in southwestern Madagascar. World Development, 96, 264-275. https://doi.org/10.1016/j.worlddev.2017.03.011

Harper, J. K., Rister, M. E., Mjelde, J. W., Drees, B. M. and Way, M. O. (1990). Factors influencing the adoption of insect management technology. American Journal of Agricultural Economics, 72(4), 997-1005. https://doi.org/10.2307/1242631 
Hashmi, M. S. (2016). Agrochemical and agricultural sustainability: A case study of Pakistan. Agricultural Sciences, 9, 1-9.

Headey, D. and Ecker, O. (2013). Rethinking the measurement of food security: From first principles to best practice. Food Security, 5(3), 327-343. https://doi.org/10.1007/s12571-0130253-0

Heckman, J. J. and Vytlacil, E. J. (2007). Handbook of Econometrics (6th ed). Elsevier B.V.

Hoffmann, S., Mai, R. and Cristescu, A. (2013). Do culture-dependent response styles distort substantial relationships? International Business Review, 22(5), 814-827. https://doi.org/10.1016/j.ibusrev.2013.01.008

Holloway, G., Ma Lucila, A. and Lapar, M. L. A. (2007). How big is your neighbourhood? Spatial implications of market participation among Filipino smallholders. Journal of Agricultural Economics, 58(1), 37-60. https://doi.org/10.1111/j.1477-9552.2007.00077.x

Hossain, M., Bose, M. L. and Mustafi, B. A. A. (2006). Adoption and productivity impact of modern rice varieties in Bangladesh. The Developing Economies, 44(2), 149-166. https://doi.org/10.1111/j.1746-1049.2006.00011.X

Iqbal, M., Khan, M. A. and Ahmad, M. (2002). Adoption of recommended varieties: A farm level analysis of wheat growers in irrigated Punjab. The Pakistan Development Review, 41(1), 2948. https://doi.org/10.30541/v41i1pp.29-48

Issa, F., Atala, T., Akpoko, J. and Sanni, S. (2016). Socio-economic determinants of adoption of recommended agrochemical practices among crop farmers in Kaduna and Ondo States, Nigeria. Asian Journal of Agricultural Extension, Economics \& Sociology, 10(1), 1-12. https://doi.org/10.9734/AJAEES/2016/22423

Jaghdani, T. J., Brümmer, B. and Barkmann, J. (2012). Comparison of methods for the valuation of irrigation water: case study from Qazvin, Iran. Irrigation and Drainage, 61(3), 375-385. https://doi.org/10.1002/ird.683

Jalal-Ud-Din, M. (2011). The socio-economic problems of small farmers in adopting new agricultural technology: A case study of three villages in district Mardan. Sarhad Journal of Agriculture, 27(2), 299-304.

Kabunga, N. S., Dubois, T. and Qaim, M. (2014). Impact of tissue culture banana technology on farm household income and food security in Kenya. Food Policy, 45, 25-34.

https://doi.org/10.1016/j.foodpol.2013.12.009 
Kaiser, H. F. (1960). The application of electronic computers to factor analysis. Educational and Psychological Measurement, 20, 141-151.

Karimov, A. A. (2014). Factors affecting efficiency of cotton producers in rural Khorezm, Uzbekistan: Re-examining the role of knowledge indicators in technical efficiency improvement. Agricultural and Food Economics, 2(1), 7. https://doi.org/10.1186/s40100-0140007-0

Kassie, M., Shiferaw, B. and Muricho, G. (2011). Agricultural technology, crop income, and poverty alleviation in Uganda. World Development, 39(10), 1784-1795. https://doi.org/10.1016/j.worlddev.2011.04.023

Kassie, M., Teklewold, H., Marenya, P., Jaleta, M. and Erenstein, O. (2015). Production risks and food security under alternative technology choices in Malawi: Application of a multinomial endogenous switching regression. Journal of Agricultural Economics, 66(3), 640-659. https://doi.org/10.1111/1477-9552.12099

Khan, A. M., Khan, A. A., Afzal, M. and Iqbal, M. S. (2012). Wheat crop yield losses caused by the aphids infestation. Journal of Biofertilizers \& Biopesticides, 03(04). https://doi.org/10.4172/2155-6202.1000122

Khan, F. Z. A., Sagheer, M., Gul, H. T., Hassan, F., Manzoor, S. A. and Wahid, A. (2013). Agricultural dynamics in Pakistan: Current issues and solutions. Russian Journal of Agricultural and Socio-Economic Sciences, 8(20), 20-26.

Khan, J. and Khattak, N. U. R. (2013). The significance of research and development for economic growth: The case of Pakistan. City University Research Journal, 3(2).

Khan, M. Azeem, Iqbal, M., Ahmad, I. and Soomro, M. H. (2002). Economic evaluation of pesticide use externalities in the cotton zones of Punjab, Pakistan. The Pakistan Development Review, 41(4II), 683-698. https://doi.org/10.30541/v41i4IIpp.683-698

Khan, D. A., Hashmi. I., Mahjabeen, W. and Naqvi, T. A. (2010). Monitoring health implications of pesticide exposure in factory workers in Pakistan. Environmental Monitoring and Assessment, 168, 231-240. https://doi: 10.1007/s10661-009-1107-2

Khan, M. M., Zhang, J., Hashmi, M. S. and Hashmi, M. S. (2011). Land distribution, technological changes and productivity in Pakistan's agriculture: some explanations and policy options. International Journal of Economics and Management Sciences, 1(1), 24. 
Khan, M. A. and Shah, S. A. A. (2011). Food insecurity in Pakistan: Causes and policy response. Journal of Agricultural and Environmental Ethics, 24(5), 493-509. https://doi.org/10.1007/s10806-010-9274-2

Khonje, M., Manda, J., Alene, A. D. and Kassie, M. (2015). Analysis of adoption and impacts of improved maize varieties in Eastern Zambia. World Development, 66, 695-706. https://doi.org/10.1016/j.worlddev.2014.09.008

Khooharo, A. A., Memon, R. A. and Mallah, M. U. (2008). An empirical analysis of pesticide marketing in Pakistan. Pakistan Economic and Social Review, 18.

Koondhar, M. A., Qiu, L., Magsi, H., Chandio, A. A. and He, G. (2018). Comparing economic efficiency of wheat productivity in different cropping systems of Sindh Province, Pakistan. Journal of the Saudi Society of Agricultural Sciences, 17(4), 398-407. https://doi.org/10.1016/j.jssas.2016.09.006

Kouser, S. and Qaim, M. (2014). Bt cotton, damage control and optimal levels of pesticide use in Pakistan. Environment and Development Economics, 19(6), 704-723. https://doi.org/10.1017/S1355770X1300051X

Krishna, V., Euler, M., Siregar, H. and Qaim, M. (2017). Differential livelihood impacts of oil palm expansion in Indonesia. Agricultural Economics, 48(5), 639-653. https://doi.org/10.1111/agec.12363

Lambert, D. M., Paudel, K. P. and Larson, J. A. (2015). Bundled adoption of precision agriculture technologies by cotton producers. Journal of Agricultural and Resource Economics, 40(2), $325-345$.

Larsen, A. F. and Lilleør, H. B. (2014). Beyond the field: The impact of farmer field schools on food security and poverty alleviation. World Development, 64, 843-859. https://doi.org/10.1016/j.worlddev.2014.07.003

Lee, D. R. (2005). Agricultural sustainability and technology adoption: Issues and policies for developing countries. American Journal of Agricultural Economics, 87(5), 1325-1334. https://doi.org/10.1111/j.1467-8276.2005.00826.x

Lewis, K.E., Grebitus, C. and Nayga Jr, R.M. (2016). The impact of brand and attention on consumers' willingness to pay: Evidence from an eye tracking experiment. Canadian Journal of Agricultural Economics, 64, 753-777.

Lokshin, M. and Glinskaya, E. (2009). The effect of male migration on employment patterns of women in Nepal. The World Bank Economic Review, 23(3), 481-507. 
https://doi.org/10.1093/wber/lhp011

Lokshin, M. and Sajaia, Z. (2004). Maximum likelihood estimation of endogenous switching regression models. The Stata Journal, 4(3), 282-289.

https://doi.org/10.1177/1536867X0400400306

Lokshin, M. and Sajaia, Z. (2011). Impact of interventions on discrete outcomes: Maximum likelihood estimation of the binary choice models with binary endogenous regressors. The Stata Journal, 11(3), 368-385.

London, L., De Grosbois, S., Wesseling, C., Kisting, S., Rother, H. A. and Mergler, D. (2002). Pesticide usage and health consequences for women in developing countries: Out of sight, out of mind? International Journal of Occupational and Environmental Health, 8, 46-59.

Makombe, G., Namara, R. E., Awulachew, S. B., Hagos, F., Ayana, M. and Kanjere, M. (2017). An analysis of the productivity and technical efficiency of smallholder irrigation in Ethiopia. Water SA, 43(1), 48. https://doi.org/10.4314/wsa.v43i1.08

Manda, L. and Wozniak, J. (2015). Farmer participation in radio campaigns for technology adoption: Lessons from AFFRI's hybrid maize campaign in Mangochi, Malawi. Journal of Development and Communication Studies, 4(1), 2. https://doi.org/10.4314/jdcs.v4i1.1

Manlosa, A. O., Hanspach, J., Schultner, J., Dorresteijn, I. and Fischer, J. (2019). Livelihood strategies, capital assets, and food security in rural Southwest Ethiopia. Food Security, 11(1), 167-181. https://doi.org/10.1007/s12571-018-00883-x

Mendola, M. (2007). Agricultural technology adoption and poverty reduction: A propensity-score matching analysis for rural Bangladesh. Food Policy, 32(3), 372-393. https://doi.org/10.1016/j.foodpol.2006.07.003

Mignouna, D. B., Manyong, V. M., Rusike, J., Mutabazi, K. D. S. and Senkondo, E. M. (2011). Determinants of adopting imazapyr-resistant maize technology and its impact on household income in Western Kenya: Journal of Development and Agricultural Economics, 3(11), 572580.

Morris, M. L., Tripp, R. and Dankyi, A. A. (1999). Adoption and impacts of improved maize production technology: A case study of the Ghana grains development project. International Maize and Wheat Improvement Centre (CIMMYT) Economics Working Paper, 99-01. Mexico. 
Mottaleb, K. A., Rahut, D. B., Ali, A., Gérard, B. and Erenstein, O. (2017). Enhancing smallholder access to agricultural machinery services: Lessons from Bangladesh. The Journal of Development Studies, 53(9), 1502-1517. https://doi.org/10.1080/00220388.2016.1257116

Mrema, E. J., Ngowi, A. V., Kishinhi, S. S. and Mamuya, S. H. (2017). Pesticide exposure and health problems among female horticulture workers in Tanzania. Environmental Health Insights, 11, 1-13. https://doi: 10.1177/1178630217715237

Mueller, N. D., Gerber, J. S., Johnston, M., Ray, D. K., Ramankutty, N. and Foley, J. A. (2012). Closing yield gaps through nutrient and water management. Nature, 490, 254-257.

Muzari, W., Gatsi, W. and Muvhunzi, S. (2012). The impacts of technology adoption on smallholder agricultural productivity in Sub-Saharan Africa: A review. Journal of Sustainable Development, 5(8), 69. https://doi.org/10.5539/jsd.v5n8p69

Mwangi, M. and Kariuki, S. (2015). Factors determining adoption of new agricultural technology by smallholder farmers in developing countries. Journal of Economics and Sustainable Development, 6(5).

Nafees, M., Jan, M. R. and Khan, H. (2008). Pesticide use in Swat valley, Pakistan: Exploring remedial measures to mitigate environmental and socioeconomic impacts. Mountain Research and Development, 28(3), 201-204. https://doi.org/10.1659/mrd.1042

Naseem, A., Omamo, S. W. and Spielman, D. J. (2006). The private sector in agricultural R\&D: Policies and institutions to foster its growth in developing countries. ISNAR Discussion Paper 6.

Nazli, H., Sarker, R., Meilke, K. and Orden, D. (2010). Economic performance of Bt cotton varieties in Pakistan. Selected paper prepared for presentation at the Agricultural and Applied Economics Association's 2010 AAEA, CAES and WAEA joint annual meeting, Denver, Colorado, July 25-27, 2010.

Negash, M. and Swinnen, J. F. M. (2013). Biofuels and food security: Micro-evidence from Ethiopia. Energy Policy, 61, 963-976. https://doi.org/10.1016/j.enpol.2013.06.031

Niles, M. T. and Salerno, J. D. (2018). A cross-country analysis of climate shocks and smallholder food insecurity. PLOS ONE, 13(2). https://doi.org/10.1371/journal.pone.0192928 
Noltze, M., Schwarze, S. and Qaim, M. (2013). Impacts of natural resource management technologies on agricultural yield and household income: The system of rice intensification in Timor Leste. Ecological Economics, 85, 59-68. https://doi.org/10.1016/j.ecolecon.2012.10.009

Nyyssola, M., Pirttilä, J. and Sandström, S. (2014). Technology adoption and food security in subsistence agriculture - evidence from a group-based aid project in Mozambique. Finnish Economic Papers, 27(1).

Oad, F. C., Siddiqui, M. H. and Buriro, U. A. (2007). Growth and yield losses in wheat due to different weed densities. Asian Journal of Plant Sciences, 6, 173-176.

Oerke, E.-C. (2006). Centenary review crop losses to pests. Journal of Agricultural Science, 144, 31-43. https://doi.org/doi:10.1017/S0021859605005708

Pakistan Bureau of statistics. (2019). Pakistan Bureau of Statistics.

Retrieved from http://www.pbs.gov.pk/

Pakistan Crop Protection Association. (2016). Pakistan current crop scenario and future opportunities. Retrieved from http://cac-pakistan.com/Uploads/Editor/2016-6-

13/Pakistan_currentCrop_Scenario_Future\%20Oppertuities_2016\%20CAC.pdf

Piesse, J. and Thirtle, C. (2010). Agricultural R\&D, technology and productivity. Philosophical Transactions of the Royal Society B: Biological Sciences, 365(1554), 3035-3047. https://doi.org/10.1098/rstb.2010.0140

Pray, C. E. and Fuglie, K. O. (2001). Private investment in agricultural research and international technology transfer in Asia. Agricultural Economics Report 805. Washington, D. C.: Economic Research Service, U.S. Department of Agriculture.

Pregibon, D. (1980). Goodness of link tests for generalized linear models. Journal of the Royal Statistical Society, 29(1), 15-23.

Pretty, J. and Bharucha, Z. P. (2014). The Sustainable intensification in agricultural systems. Annals of Botany, 114(8), 1571-1596. https://doi.org/10.1093/aob/mcu205

Qaim, M. and Kouser, S. (2013). Genetically modified crops and food security. PLOS ONE, 8(6), e64879. https://doi.org/10.1371/journal.pone.0064879

Rehman, H. U. (2012). The problem of unemployment in Pakistan: A case of study of Khyber Pakhtunkhwa. International Journal of Humanities and Social Science, 2(8), 237-243. 
Rehman, A., Jingdong, L., Shahzad, B., Chandio, A. A., Hussain, I., Nabi, G. and Iqbal, M. S. (2015). Economic perspectives of major field crops of Pakistan: An empirical study. Pacific Science Review B: Humanities and Social Sciences, 1(3), 145-158. https://doi.org/10.1016/j.psrb.2016.09.002

Rehman, A., Jingdong, L., Chandio, A. A., Hussain, I., Wagan, S. A. and Memon, Q. U. A. (2019). Economic perspectives of cotton crop in Pakistan: A time series analysis (1970-2015) (Part 1). Journal of the Saudi Society of Agricultural Sciences, 18(1), 49-54. https://doi.org/10.1016/j.jssas.2016.12.005

Report. (2015). Causes of low yield of cotton during cotton crop season 2015. Report of committee constituted by agriculture department. University of agriculture, Faisalabad. Retrieved from http://uaf.edu.pk/oubm/Files/Reports/Report\%206/6.\%20CAUSES\%20OF\%20LOW\%20YI ELD\%20OF\%20COTTON.pdf

Ricker-Gilbert, J. and Jones, M. (2015). Does storage technology affect adoption of improved maize varieties in Africa? Insights from Malawi's input subsidy program. Food Policy, 50, 92-105. https://doi.org/10.1016/j.foodpol.2014.10.015

Rogers, E. M. (1983). Diffusion of innovations (3rd ed). Free Press; Collier Macmillan.

Rotterdam convention. (2019). Rotterdam convention. Retrieved from

http://www.pic.int/Countries/CountryProfiles/tabid/1087/language/en-US/Default.aspx

Salazar, L., Aramburu, J., González-Flores, M. and Winters, P. (2015). Food security and productivity: impacts of technology adoption in small subsistence farmers in Bolivia. IDB working paper series; 567.

Saqib, R. and Tachibana, S. (2014). An insight into farmers' views on factors affecting the adoption of innovations introduced by agricultural and forestry extension services in mountainous regions. International Journal of Innovative and Applied Research, 2(8), 31-40.

Schreinemachers, P., Wu, M., Uddin, Md. N., Ahmad, S. and Hanson, P. (2016). Farmer training in off-season vegetables: Effects on income and pesticide use in Bangladesh. Food Policy, 61, 132-140. https://doi.org/10.1016/j.foodpol.2016.03.002

Sharifzadeh, M., Abdollahzadeh, G., Damalas, C. and Rezaei, R. (2018). Farmers' criteria for pesticide selection and use in the pest control process. Agriculture, 8(2), 24. https://doi.org/10.3390/agriculture8020024

Shiferaw, B., Kassie, M., Jaleta, M. and Yirga, C. (2014). Adoption of improved wheat varieties and impacts on household food security in Ethiopia. Food Policy, 44, 272-284. 
https://doi.org/10.1016/j.foodpol.2013.09.012

Shikuku, K. M., Winowiecki, L., Twyman, J., Eitzinger, A., Perez, J. G., Mwongera, C. and Läderach, P. (2017). Smallholder farmers' attitudes and determinants of adaptation to climate risks in East Africa. Climate Risk Management, 16, 234-245.

https://doi.org/10.1016/j.crm.2017.03.001

Simtowe, F., Asfaw, S. and Abate, T. (2016). Determinants of agricultural technology adoption under partial population awareness: The case of pigeonpea in Malawi. Agricultural and Food Economics, 4(1), 7. https://doi.org/10.1186/s40100-016-0051-z

Spielman, D. J., Zaidi, F., Zambrano, P., Khan, A. A., Ali, S., Cheema, H. M. N., Nazli, H., Khan, R. S. A., Iqbal, A., Zia, M. A. and Ali, G. M. (2017). What are farmers really planting? Measuring the presence and effectiveness of Bt cotton in Pakistan. PLOS ONE, 12(5). https://doi.org/10.1371/journal.pone.0176592

Spielman, D. and Kouser, S. (2018). The impact of Bt cotton on farmers' health in Pakistan. International Association of Agricultural Economists (IAAE) Conference, July 28-August 2, 2018, Vancouver, British Columbia.

Stockholm convention. (2019). Stockholm convention.

Retrieved from

http://www.pops.int/Countries/StatusofRatifications/PartiesandSignatoires/tabid/4500/Defaul t.aspx

Sudman, S. (1976). Applied Sampling. New York: Academic Publishers.

Tariq, M. I., Afzal, S., Hussain, I. and Sultana, N. (2007). Pesticides exposure in Pakistan: A review. Environment International, 33(8), 1107-1122. https://doi.org/10.1016/j.envint.2007.07.012

Tellis, G. J. and Chandrasekaran, D. (2010). Extent and impact of response biases in cross-national survey research. International Journal of Research in Marketing, 27(4), 329-341. https://doi.org/10.1016/j.jiresmar.2010.08.003

Tesfaye, W. and Tirivayi, N. (2018). The impacts of postharvest storage innovations on food security and welfare in Ethiopia. Food Policy, 75, 52-67. https://doi.org/10.1016/j.foodpol.2018.01.004

Thapa, G. and Gaiha, R. (2011). Smallholder farming in Asia and the pacific: challenges and opportunities. Asian Journal of Agriculture and Development, 9(1), 53-89. 
The Government of Pakistan. (2000). Pakistan economic survey 1999-2000. Retrieved from http://www.finance.gov.pk/survey_1617.html

The Government of Pakistan. (2018a). Department of plant protection ministry of national food security and research, Pakistan. Retrieved from http://plantprotection.gov.pk

The Government of Pakistan. (2018b). Ministry of national food security and research Islamabad.

Retrieved from

http://www.mnfsr.gov.pk/userfiles1/file/National\%20Food\%20Security\%20Policy\%20\%202 $018 \% 20(1) . p d f$

The Government of Pakistan. (2019a). Pakistan economic survey 2018-19. Retrieved from http://www.finance.gov.pk/survey/chapters_19/12-Population.pdf

The Government of Pakistan. (2019b). Pakistan economic survey 2018-19. Retrieved from http://www.finance.gov.pk/survey/chapters_19/8-Trade\%20and\%20payments.pdf

The Government of Punjab. (2010). Punjab development statistics. Retrieved from http://bos.gop.pk/developmentstat

The Government of Punjab. (2015). Punjab development statistics. Retrieved from http://bos.gop.pk/developmentstat

The Government of Punjab. (2016). Punjab development statistics. Retrieved from http://bos.gop.pk/developmentstat

The Royal Society (London). (2009). Reaping the benefits science and the sustainable intensification of global agriculture. The Royal Society.

Thirtle, C., Piesse, J. and Gouse, M. (2005). Agricultural technology, productivity and employment: Policies for poverty reduction. Agrekon, 44(1), 37-59. https://doi.org/10.1080/03031853.2005.9523702

Tijani, A. and Nurudeen, S. (2012a). Factors determining the extent of pesticide use in Nigerian farms. Journal of Agricultural Economics and Development, 1(1), 1-9.

Tijani, A. and Nurudeen, S. (2012b). Assessment of farm level pesticide use among maize farmers in Oyo state, Nigeria. Food Science and Quality Management, 3, 1-8.

Tilman, D., Cassman, K. G., Matson, P. A., Naylor, R. and Polasky, S. (2002). Agricultural sustainability and intensive production practices. Nature, 418(6898), 671-677. https://doi.org/10.1038/nature01014

UNDP. (2001). Policy and strategy for the rational use of pesticides in Pakistan, building consensus for action, UNDP / FAO Paper, Rome, Italy. 
USDA. (2016). United States Department of Agriculture.

Retrieved from http://www.usda.gov/oce/sustainable/definitions.html

Verbeke, W. and Ward, R. W. (2006). Consumer interest in information cues denoting quality, traceability and origin: An application of ordered probit models to beef labels. Food Quality and Preference, 17(6), 453-467. https://doi.org/10.1016/j.foodqual.2005.05.010

Vergragt, P. J. (2006). How technology could contribute to a sustainable world. GTI Paper Series.

Willy, D. K. and Holm-Müller, K. (2013). Social influence and collective action effects on farm level soil conservation effort in rural Kenya. Ecological Economics, 90, 94-103.

Wilson, C. and Tisdell, C. (2001). Why farmers continue to use pesticides despite environmental, health and sustainability costs. Ecological Economics, 39(3), 449-462.

https://doi.org/10.1016/S0921-8009(01)00238-5

Wilson, W. J. (1987). The Truly Disadvantaged: The Inner City, the Underclass, and Public Policy. University of Chicago Press.

Wooldridge, J. M. (2010). Econometric analysis of cross section and panel data (2nd ed). MIT Press. 


\section{Appendix}

Agricultural Inputs Uses, Social, and Food Security Characteristics of Smallholder in Pakistan

(Questionnaire)

Introduction to respondent: I am... from ... collecting data on behalf of Mr. Muhammad Bilal, (a Ph.D. student from Germany) on Agricultural Inputs Uses, Social, and Food Security Characteristics of Smallholder in Pakistan. Your responses are very helpful to improve future policies and programmes regarding the smallholder. Your responses will be exclusively used for research purposes and will be treated as confidential.

We will respect all your answers and appreciate your cooperation, are you willing to participate in this survey?

If 'Yes' continue for the interview, if 'No' then please stop here.

Questionnaire Code:

GPS Location:

Name of Interviewer:

\section{Area details:}

1.1 Country:

1.3 District:

1.5 Union Council:
1.2 Province:

1.4 Tehsil:

1.6 Village:

\section{Basic Household Characteristics of Farmer:}

2.1 Gender:

2.2 Name of Respondents:

First Name: Middle Name: Last Name:

2.3 Age:

2.4 Respondent the head of the household Yes $=1$; Otherwise $=0$; (if 0 then ask 2.6)

2.5 Marital status Married=1; unmarried=0;

2.6 Household Head Male=1; Female=0;

2.7 Ethnicity:

2.8 Number of years of residence in this village:

2.9 Total house members:

2.10 Total number of males in house:

2.11 Number of males over 18 years of age:

2.12 Total education of respondent in years: 


\section{Access to basic social facilities:}

\begin{tabular}{|l|l|}
\hline Facilities & Distance in $\mathrm{Km}$ \\
\hline 3.1 School & \\
\hline 3.2 Basic health Centre & \\
\hline 3.3 Veterinary Hospital & \\
\hline 3.4 Agriculture Bank/Commercial Bank & \\
\hline 3.5 Post office & \\
\hline 3.6 Police station/Police chowki & \\
\hline 3.7 Do you have mobile phone access: Yes $=1 ; \mathrm{No}=0$ & \\
\hline 3.8 Do you have internet access: Yes=1; No=0 & \\
\hline 3.9 Mode of transportation you used please specify & \\
\hline
\end{tabular}

What is the main source of drinking water in your house? Please tick only one

\begin{tabular}{|l|l|l|}
\hline 3.10.1 Drum water & 3.10 .2 Tap water & \\
\hline 3.10.3 Hand pump & 3.10.4 Motor pump & \\
\hline 3.10.5 Well & 3.10.6 River & \\
\hline 3.10.7 Lake & 3.10.8 Other, please specify & \\
\hline
\end{tabular}

What is the main source of energy (light) in your home/farm? Please tick only one

\begin{tabular}{|l|l|}
\hline 3.11 .1 Electricity & \\
\hline 3.11 .2 Generator & \\
\hline 3.11.3 Kerosene lamp & \\
\hline 3.11 .4 Other, please specify & \\
\hline
\end{tabular}

What is the main source of fuel in your home? Please tick only one

3.12.1 Electric Stove

3.12.3 Sui Gas Connection

3.12.5 Gas cylinder

3.12.7 Coal
3.12.2 Wood

3.12.4 Dung

3.12.6 Crop residue

3.12.8 Other, please specify 


\section{Access to agriculture facilities / Information:}

4.1 Distance of Agriculture Extension office from your farm in Km:

4.3 Number of field visits to farmers by Agri-Ext representative per month:

4.4 Number of field visits by private agricultural firms' representative per month:

4.5 Number of visits by Veterinary or para-veterinary per month:

4.6 Information about Agricultural Credit:

\begin{tabular}{|l|l|}
\hline 4.6.1 Do You have access to Credit? Yes $=1 ; \mathrm{No}=0$ \\
\hline 4.6.2 Did you applied for credit? Yes $=1 ; \mathrm{No}=0$ & \multicolumn{2}{|l|}{ (Tick the relevant) } \\
\hline If Yes from which of the following sources & \\
\hline 4.6.3 Government banks (ZTBL, National bank) & \\
\hline 4.6.4 Private Commercial Bank & \\
\hline 4.6.5 NGO & \\
\hline 4.6.6 Input supplier/Distributors & \\
\hline 4.6.7 Private Money lender & \\
\hline 4.6.8 Friends/Relatives & \\
\hline 4.6.9 Other & \\
\hline
\end{tabular}

\section{Information regarding social indicators of farmers (a):}

\begin{tabular}{|l|c|c|c|c|c|}
\hline $\begin{array}{l}\text { 5.1 How you will compare yourself to } \\
\text { the all other people in this village. }\end{array}$ & $\begin{array}{c}\text { Little } \\
\text { worst off }\end{array}$ & $\begin{array}{c}\text { Much worst } \\
\text { off }\end{array}$ & $\begin{array}{c}\text { Like most of } \\
\text { others }\end{array}$ & $\begin{array}{c}\text { Little bit better } \\
\text { off }\end{array}$ & $\begin{array}{c}\text { Much better } \\
\text { off }\end{array}$ \\
\hline & & & & & \\
\hline
\end{tabular}

Where: $1=$ little worst off, $2=$ Much worst off, $3=$ Like most of others, $4=$ little bit better off, and $5=$ Much better off. (Please tick the relevant box) 


\begin{tabular}{|c|c|c|c|c|c|c|c|c|}
\hline \multicolumn{9}{|c|}{5.2 Information about main activities over the calendar year (Please tick the relevant Months) } \\
\hline \multicolumn{9}{|c|}{ Important: Food shortage means not enough food and grain to meet daily household consumptions. } \\
\hline Months & $\begin{array}{l}\text { Land } \\
\text { Preparation }\end{array}$ & Cultivation & Harvesting & Threshing & $\begin{array}{l}\text { Buying } \\
\text { and } \\
\text { selling of } \\
\text { milk } \\
\text { animals }\end{array}$ & $\begin{array}{l}\text { Buying of } \\
\text { crop } \\
\text { protection } \\
\text { products }\end{array}$ & $\begin{array}{l}\text { In which } \\
\text { months you } \\
\text { expect } \\
\text { shortage of } \\
\text { food? }\end{array}$ & $\begin{array}{l}\text { Other } \\
\text { please } \\
\text { Specify }\end{array}$ \\
\hline \multicolumn{9}{|l|}{ January } \\
\hline \multicolumn{9}{|l|}{ February } \\
\hline \multicolumn{9}{|l|}{ March } \\
\hline \multicolumn{9}{|l|}{ April } \\
\hline \multicolumn{9}{|l|}{ May } \\
\hline \multicolumn{9}{|l|}{ June } \\
\hline \multicolumn{9}{|l|}{ July } \\
\hline \multicolumn{9}{|l|}{ August } \\
\hline \multicolumn{9}{|l|}{ September } \\
\hline \multicolumn{9}{|l|}{ October } \\
\hline \multicolumn{9}{|l|}{ November } \\
\hline December & & & & & & & & \\
\hline
\end{tabular}




\begin{tabular}{|c|c|c|c|}
\hline \multicolumn{4}{|c|}{ 5.3 Information about Household Food Access (a) } \\
\hline \# & QUESTION & $\begin{array}{l}\text { RESPONSE } \\
\text { OPTIONS }\end{array}$ & RESPONSE \\
\hline 5.3 .1 & $\begin{array}{l}\text { In the month of food shortage, did you have anxiety } \\
\text { that you and any of your household would not have } \\
\text { enough food? }\end{array}$ & $\begin{array}{l}0=\text { Never } \\
1=\text { Rarely } \\
2=\text { Sometimes } \\
3=\text { Often }\end{array}$ & \\
\hline 5.3 .2 & $\begin{array}{l}\text { In the month of food shortage, were you and any of } \\
\text { your household remains unable to eat the specific } \\
\text { types of foods you like due to resource constraints? }\end{array}$ & $\begin{array}{l}0=\text { Never } \\
1=\text { Rarely } \\
2=\text { Sometimes } \\
3=\text { Often }\end{array}$ & \\
\hline 5.3 .3 & $\begin{array}{l}\text { In the month of food shortage, did you and any of your } \\
\text { household have to eat limited types of foods because } \\
\text { of resource constraints? }\end{array}$ & $\begin{array}{l}0=\text { Never } \\
1=\text { Rarely } \\
\text { 2=Sometimes } \\
3=\text { Often }\end{array}$ & \\
\hline 5.3 .4 & $\begin{array}{l}\text { In the month of food shortage, did you and any of your } \\
\text { household have to eat some types of foods that you and } \\
\text { they really not preferred to eat due to resource } \\
\text { constraints to have other varieties of food? }\end{array}$ & $\begin{array}{l}0=\text { Never } \\
1=\text { Rarely } \\
2=\text { Sometimes } \\
3=\text { Often }\end{array}$ & \\
\hline 5.3 .5 & $\begin{array}{l}\text { In the month of food shortage, did you and any of your } \\
\text { household have to eat a less quantity of meal than you } \\
\text { felt you needed due to not enough food? }\end{array}$ & $\begin{array}{l}0=\text { Never } \\
1=\text { Rarely } \\
2=\text { Sometimes } \\
3=\text { Often }\end{array}$ & \\
\hline 5.3 .6 & $\begin{array}{l}\text { In the month of food shortage, did you and any of your } \\
\text { household have to eat fewer meals in a day due to not } \\
\text { enough food? }\end{array}$ & $\begin{array}{l}0=\text { Never } \\
1=\text { Rarely } \\
2=\text { Sometimes } \\
3=\text { Often }\end{array}$ & \\
\hline 5.3 .7 & $\begin{array}{l}\text { In the month of food shortage, were you and your } \\
\text { household remain foodless of any kind due to lack of } \\
\text { resources to obtain food? }\end{array}$ & $\begin{array}{l}0=\text { Never } \\
1=\text { Rarely } \\
2=\text { Sometimes } \\
3=\text { Often }\end{array}$ & \\
\hline 5.3 .8 & $\begin{array}{l}\text { In the month of food shortage, did you and any of your } \\
\text { household go to sleep at night hungry due to not } \\
\text { enough food? }\end{array}$ & $\begin{array}{l}0=\text { Never } \\
1=\text { Rarely } \\
\text { 2=Sometimes } \\
3=\text { Often }\end{array}$ & \\
\hline 5.3 .9 & $\begin{array}{l}\text { In the month of food shortage, did you and any of your } \\
\text { household remains hungry for full day and night due } \\
\text { to not enough food? }\end{array}$ & $\begin{array}{l}0=\text { Never } \\
1=\text { Rarely } \\
2=\text { Sometimes } \\
3=\text { Often }\end{array}$ & \\
\hline
\end{tabular}




\subsection{Information regarding social indicators of farmers (b)}

\begin{tabular}{|l|l|l|l|}
\hline $\begin{array}{l}\text { Are you or any member of your Hh a } \\
\text { member of any of the following } \\
\text { associations /organisation/groups? }\end{array}$ & Yes=1 & No=0 & $\begin{array}{l}\text { If Yes how often do you attend } \\
\text { association meetings } \\
\text { (number/month) }\end{array}$ \\
\hline Farmers Association & & & \\
\hline Farmers Field School & & & \\
\hline $\begin{array}{l}\text { Community/Neighbourhood } \\
\text { committee }\end{array}$ & & & \\
\hline NGO's & & & \\
\hline Member of Mosque committee & & & \\
\hline Village Aman/Zakat committee & & & \\
\hline Other, Please Specify & & & \\
\hline
\end{tabular}

\subsection{Housing structure of the Household}

5.5.1 Boundary wall $\mathrm{Yes}=1 ; \mathrm{No}=0$

5.5.3 Cemented $\mathrm{Yes}=1 ; \mathrm{No}=0$

5.5.5 Concrete floor $\mathrm{Yes}=1 ; \mathrm{No}=0$ 5.5.2 Toilet flush system $\mathrm{Yes}=1 ; \mathrm{No}=0$

5.5.4 Number of rooms

5.5.6 Number of toilets

\section{Farms and Geographic Specific Attributes:}

6.1 Total Area under cultivation:

6.2 Own:

6.3 Rented in:

6.4 what is the rent of land/acre:

(Rs)

6.5 Please give estimated value (price) of an acre if it would to be sold:

\begin{tabular}{|l|l|}
\hline 6.6 Farms Specific Attributes & Yes $=1 ; \mathrm{No}=0 ; \mathrm{Both}=2$ \\
\hline 6.6.1 Distance of farm from Tehsil in $\mathrm{Km}:$ & \\
\hline 6.6.2 Distance of farm from Input Market in $\mathrm{Km}:$ & \\
\hline 6.6.3 Travelled time to Input Marker in minutes: & \\
\hline 6.6.4 Distance of farm from output Market in $\mathrm{Km}:$ & \\
\hline 6.6.5 Travelled time to Output Marker in minutes: & \\
\hline 6.6.6 Distance of farm from the head of village farm in $\mathrm{Km}:$ & \\
\hline 6.6.7 Distance of farm to Metalled Road in $\mathrm{Km}:$ & \\
\hline 6.6.8 Irrigated=1; Unirrigated $=0$ & \\
\hline 6.6.9 Canal irrigation $=1 ;$ Tube well $=0 ;$ Both $=2$ & \\
\hline 6.6.10 Tube well Own Yes $=1 ;$ Otherwise/ $\mathrm{No}=0$ & \\
\hline 6.6.11 Tube well cost & \\
\hline
\end{tabular}




\section{Information about Soil quality of farming unit:}

\begin{tabular}{|c|c|c|c|c|c|c|c|c|c|}
\hline \multicolumn{5}{|c|}{$\begin{array}{l}\text { 7.1 How would you describe the soil quality of } \\
\text { your farm? Encircle the relevant box below }\end{array}$} & \multicolumn{5}{|c|}{$\begin{array}{l}\text { 7.2 Are you practicing any of the following measures on your farm? } \\
\text { Please show images }\end{array}$} \\
\hline $\begin{array}{l}\text { Very } \\
\text { fertile }\end{array}$ & Fertile & $\begin{array}{l}\text { Medium } \\
\text { fertile }\end{array}$ & $\begin{array}{l}\text { Less } \\
\text { fertile }\end{array}$ & $\begin{array}{l}\text { No } \\
\text { idea }\end{array}$ & $\begin{array}{l}7.2 .1 \\
\text { Inter- } \\
\text { cropping } \\
\text { Yes }=1 \text {; } \\
\text { No }=0\end{array}$ & $\begin{array}{l}7.2 .2 \\
\text { Crop rotation } \\
\text { Yes }=1 ; \\
\text { No }=0\end{array}$ & $\begin{array}{l}7.2 .3 \\
\text { Laser } \\
\text { levelling } \\
\text { Yes }=1 \text {; } \\
\text { No }=0\end{array}$ & $\begin{array}{l}7.2 .4 \\
\text { No-tillage } \\
\text { Yes }=1 ; \\
\text { No }=0\end{array}$ & $\begin{array}{l}7.2 .5^{*} \\
\text { Other } \\
\text { please } \\
\text { specify }\end{array}$ \\
\hline 1 & 2 & 3 & 4 & 5 & & & & & \\
\hline
\end{tabular}

$*$

\subsection{Information about input quality \& quantity:}

We are showing you three different types of pesticides, each different type includes pesticides, weedicides, fungicides and seed treatments.

8.1.1 Have you been using the Product type A currently or in past 5 years:

8.1.2 What is your knowledge and your view about product type A:

8.1.3 If product $\mathrm{A}$ is identified and used, which one \& since when you are using Product A?

\begin{tabular}{|l|l|l|}
\hline Types of Product A & Tick the relevant box & Duration \\
\hline 8.1 .3 .1 Insecticides & & \\
\hline 8.1 .3 .2 Fungicides & & \\
\hline 8.1 .3 .3 Weedicides & & \\
\hline 8.1 .3 .4 Seed treatment & & \\
\hline Other & & \\
\hline
\end{tabular}

8.1.4 Have you been using the Product type B currently or in past 5 years:

8.1.5 What is your knowledge and your view about product type B:

8.1.6 If product B is identified and used, which one \& since when you are using Product B? 


\begin{tabular}{|l|l|l|}
\hline Types of Product B & Tick the relevant box & Duration \\
\hline 8.1.6.1 Insecticides & & \\
\hline 8.1.6.2 Fungicides & & \\
\hline 8.1.6.3 Weedicides & & \\
\hline 8.1.6.4 Seed treatment & & \\
\hline Other & & \\
\hline
\end{tabular}

8.1.7 Have you been using the Product type C currently or in past 5 years:

8.1.8 What is your knowledge and your view about product type C:

8.1.9 If product $\mathrm{C}$ is identified and used, which one \& since when you are using Product $\mathrm{C}$ ?

\begin{tabular}{|l|l|l|}
\hline Types of Product C & Tick the relevant box & Duration \\
\hline 8.1.9.1 Insecticides & & \\
\hline 8.1 .9 .2 Fungicides & & \\
\hline 8.1 .9 .3 Weedicides & & \\
\hline 8.1 .9 .4 Seed treatment & & \\
\hline Other & & \\
\hline
\end{tabular}

8.1.10 Products specification for different crops: Product $\mathbf{A}=\mathbf{1}$, Product $\mathbf{B}=\mathbf{2}$, and Product $\mathbf{C}=\mathbf{3}$, and if respondents do not apply any one of the listed products $=$ N/A.

\begin{tabular}{|l|l|l|l|l|l|}
\hline Name of crop & Pesticide & Fungicide & Weedicide & Seed treatment & $\begin{array}{l}\text { Total cost/ } \\
\text { Acre }\end{array}$ \\
\hline & & & & & \\
\hline & & & & & \\
\hline & & & & & \\
\hline & & & & & \\
\hline & & & & & \\
\hline & & & & & \\
\hline
\end{tabular}

Code: 8.1.10.1Wheat=1, 8.1.10.2Rice=2, 8.1.10.3Sugarcane=3, 8.1.10.4 Cotton=4, 8.1.10.5 Maize=5, 8.1.10.6

Other $=6$

Adoption status? (Please fill according to above answer)

\begin{tabular}{|l|l|}
\hline After demonstration of three different samples, tick the relevant answer \\
\hline Product type A & \\
\hline Product type B & \\
\hline Product type C & \\
\hline
\end{tabular}


8.2 From which of the following source you have heard about these different types? (Please tick the relevant box)

\begin{tabular}{|l|l|}
\hline 8.2.1 Friends/Neighbourhood farmers & \\
\hline 8.2.2 Farmer's union meetings & \\
\hline 8.2.3 Newspaper/TV/Radio & \\
\hline 8.2.4 NGO & \\
\hline 8.2.5 Private firm's representatives & \\
\hline 8.2.6 Distributors & \\
\hline 8.2.7 Extension service & \\
\hline 8.2.8 Other please specify & \\
\hline
\end{tabular}

\begin{tabular}{|l|l|l|l|l|}
\hline $\begin{array}{l}\text { Name of } \\
\text { Crop }\end{array}$ & $\begin{array}{l}8.2 .9 \text { Urea } \\
\text { Bags/Acre }\end{array}$ & $\begin{array}{l}8.2 .10 \text { DAP } \\
\text { Bags/Acre }\end{array}$ & $\begin{array}{l}\text { 8.2.11Others } \\
\text { Bags/Acre }\end{array}$ & 8.2.12 Total Cost/Acre \\
\hline & & & & \\
\hline & & & & \\
\hline & & & & \\
\hline & & & & \\
\hline & & & & \\
\hline
\end{tabular}

Code: Wheat $=1$, Rice $=2$, Sugarcane $=3$, Cotton $=4$, Maize $=5$, Other $=6$

\begin{tabular}{|l|l|l|l|}
\hline Name of Crop & $\begin{array}{l}8.2 .13 \text { Number of Manures } \\
\text { Trolley's/Acre }\end{array}$ & 8.2 .14 Cost/ Trolley & 8.2 .15 Total Cost/Acre \\
\hline & & & \\
\hline & & & \\
\hline & & & \\
\hline & & & \\
\hline & & & \\
\hline
\end{tabular}

Code: Wheat $=1$, Rice $=2$, Sugarcane $=3$, Cotton $=4$, Maize $=5$, Other $=6$

\begin{tabular}{|l|l|l|}
\hline Name of Crop & $\begin{array}{l}8.2 .16 \text { Bt-Cotton= } 1 ; \text { Improved/Hybrid Saeed variety }=2 ; \\
\text { Domestic/local variety; otherwise }=0\end{array}$ & 8.2 .17 Cost/Acre \\
\hline & & \\
\hline & & \\
\hline & & \\
\hline & & \\
\hline & & \\
\hline & & \\
\hline
\end{tabular}

Code: Wheat $=1$, Rice $=2$, Sugarcane $=3$, Cotton $=4$, Maize $=5$, Other $=6$ 


\section{Access to Farm Machinery:}

8.3 Farm Machinery own=1; otherwise $=0$; 8.4 If yes, Specification of farm machinery:

\begin{tabular}{|l|l|l|l|l|l|}
\hline Name of Machine & $\begin{array}{l}\text { Yes=1; } \\
\text { Otherwise=0 }\end{array}$ & Model & $\begin{array}{l}\text { Since when you are } \\
\text { using this? }\end{array}$ & $\begin{array}{l}\text { Price of Machine } \\
\text { (Used) }\end{array}$ & $\begin{array}{l}\text { Price of Machine } \\
\text { (New) Market info }\end{array}$ \\
\hline 8.4.1 Tractor & & & & & \\
\hline 8.4.2 Trolley & & & & & \\
\hline 8.4.3 Thresher & & & & & \\
\hline 8.4.4 Rotavator & & & & & \\
\hline 8.4.5 Plough & & & & & \\
\hline 8.4.6 Spray machine & & & & & \\
\hline 8.4.7 Other & & & & & \\
\hline
\end{tabular}

8.5 Livestock own $=1$ ; otherwise $=0$;

8.6 If yes, Number of Milk Animals;

8.6.1 Number of Oxen; ; 8.6.2 Number of Donkey; ; 8.6.3 Number of Sheep \& Goat;

\section{Output per Acre 2017:}

\begin{tabular}{|c|c|c|c|c|c|c|c|}
\hline $\begin{array}{l}\text { Name } \\
\text { of Crop }\end{array}$ & $\begin{array}{l}\text { 9.1Total } \\
\text { area sown } \\
\text { in acre }\end{array}$ & $\begin{array}{l}9.2 \text { Yield } \\
\text { Mounds/Acre } \\
\text { in } 2017\end{array}$ & $\begin{array}{l}9.3 \text { Marketed/ } \\
\text { Sold in } \\
\text { Mounds }\end{array}$ & \begin{tabular}{|l|} 
9.4 Left in \\
stock after sale
\end{tabular} & $\begin{array}{l}\text { 9.5 Price/ } \\
\text { Mounds in Rs }\end{array}$ & $\begin{array}{l}9.6 \text { Total } \\
\text { value in } \\
\text { Rs }\end{array}$ & $\begin{array}{l}9.7 \text { Total } \\
\text { yield in } \\
2017\end{array}$ \\
\hline & & & & & & & \\
\hline & & & & & & & \\
\hline & & & & & & & \\
\hline & & & & & & & \\
\hline & & & & & & & \\
\hline & & & & & & & \\
\hline
\end{tabular}

Code: Wheat $=1$, Rice $=2$, Sugarcane $=3$, Cotton $=4$, Maize $=5$, Other $=6$ 


\section{Distribution of labour force:}

\begin{tabular}{|c|c|c|c|c|c|c|c|c|c|c|c|}
\hline \multicolumn{6}{|c|}{ Family Labour who works for crop production only } & \multicolumn{6}{|c|}{$\begin{array}{l}\text { Permanent Hired Labour who works for crop production } \\
\text { only }\end{array}$} \\
\hline $\begin{array}{l}10.1 \mathrm{No} \\
\text { of } \\
\text { Males }\end{array}$ & \begin{tabular}{|l|}
$10.2 \quad$ No \\
of \\
Females
\end{tabular} & \begin{tabular}{|l|}
10.3 \\
Months/ \\
year
\end{tabular} & $\begin{array}{l}10.4 \\
\text { Weeks/ } \\
\text { month }\end{array}$ & $\begin{array}{l}10.5 \\
\text { Days/ } \\
\text { week }\end{array}$ & \begin{tabular}{|l|}
10.6 \\
Hours/ \\
day \\
\end{tabular} & $\begin{array}{l}10.7 \text { No } \\
\text { of Males }\end{array}$ & \begin{tabular}{|l}
10.8 No \\
of \\
Females \\
\end{tabular} & $\begin{array}{l}10.9 \\
\text { Months/ } \\
\text { year }\end{array}$ & \begin{tabular}{|l}
10.10 \\
Week/ \\
month
\end{tabular} & $\begin{array}{l}10.11 \\
\text { Days/ } \\
\text { week }\end{array}$ & $\begin{array}{l}10.12 \\
\text { Hours/day }\end{array}$ \\
\hline & & & & & & & & & & & \\
\hline & & & & & & & & & & & \\
\hline & & & & & & & & & & & \\
\hline & & & & & & & & & & & \\
\hline & & & & & & & & & & & \\
\hline & & & & & & & & & & & \\
\hline & & & & & & & & & & & \\
\hline
\end{tabular}

\begin{tabular}{|c|c|c|c|l|l|l|}
\hline Year & \multicolumn{2}{|c|}{$\begin{array}{c}\text { 10.13 Salary of permanent hired } \\
\text { labour at village Rs/month }\end{array}$} & \multicolumn{2}{|c|}{$\begin{array}{c}\text { 10.14 Salary of seasonal labour at } \\
\text { village Rs/day }\end{array}$} & \multicolumn{2}{|c|}{$\begin{array}{c}\text { 10.15 Number of seasonal labours } \\
\text { employed at your farm in } 2017\end{array}$} \\
\hline \multirow{2}{*}{2017} & 10.13 .1 Male & 10.13 .2 Female & 10.14 .1 Male & 10.14 .2 Female & 10.15 .1 Male & 10.15 .2 Female \\
\cline { 2 - 7 } & & & & & & \\
\hline
\end{tabular}

\section{Household Off-farm income:}

\begin{tabular}{|c|c|c|c|c|c|c|c|c|c|}
\hline \multicolumn{10}{|c|}{ Number of Household engaged in Off-Farm Income? } \\
\hline \multicolumn{2}{|c|}{$\begin{array}{l}\text { 11.1 How much } \\
\text { time Hh members } \\
\text { devote for off-farm } \\
\text { activity }\end{array}$} & \multicolumn{2}{|c|}{$\begin{array}{l}11.2 \text { Number of } \\
\text { Hh members } \\
\text { engaged in off- } \\
\text { farm activities }\end{array}$} & \multicolumn{2}{|c|}{$\begin{array}{l}\text { 11.3 Education level } \\
\text { of Hh members } \\
\text { involve in off- farm } \\
\text { activity }\end{array}$} & \multicolumn{2}{|c|}{$\begin{array}{l}\text { 11.4 Age of Hh } \\
\text { members engaged in } \\
\text { off-farm activity }\end{array}$} & \multicolumn{2}{|c|}{$\begin{array}{l}\text { 11.5 Total income from } \\
\text { off-farm activities in (Rs) }\end{array}$} \\
\hline $\begin{array}{l}11.1 .1 \\
\text { Days/ } \\
\text { week }\end{array}$ & $\begin{array}{c}11.1 .2 \\
\text { Hours/ } \\
\text { Day } \\
\end{array}$ & $\begin{array}{l}11.2 .1 \\
\text { Male }\end{array}$ & $\begin{array}{c}11.2 .2 \\
\text { Female }\end{array}$ & $\begin{array}{l}11.3 .1 \\
\text { Male }\end{array}$ & $\begin{array}{c}11.3 .2 \\
\text { Female }\end{array}$ & $\begin{array}{l}\text { 11.4.1 } \\
\text { Male }\end{array}$ & $\begin{array}{l}11.4 .2 \\
\text { Female }\end{array}$ & $\begin{array}{l}\text { 11.5.1 } \\
\text { Male }\end{array}$ & $\begin{array}{l}11.5 .2 \\
\text { Female }\end{array}$ \\
\hline & & & & & & & & & \\
\hline & & & & & & & & & \\
\hline & & & & & & & & & \\
\hline & & & & & & & & & \\
\hline
\end{tabular}

\section{Input specific aspects of sample farmers.}

12.1 When you need agricultural information who do you turn for from the following?

Neighbourhood farmers =1; Village committee $=2$; Newspaper/TV/Radio=3; Private firms rep=4; Distributors $=\mathbf{5} ; \mathrm{NGO}=\mathbf{6}$; Extension dept. $=\mathbf{7}$;

12.2 Do you listen to agricultural radio or TV programmes? Yes=1; No=0; 
12.3 Do you listen to agricultural information via cell phone (input prices, agricultural practices)

Yes=1; No=0;

12.4 Do you hire expert for spraying? Yes=1; No=0;

\begin{tabular}{|l|l|l|l|l|l|}
\hline $\begin{array}{l}\text { 12.5 What is your opinion about quality of } \\
\text { agricultural information's about advanced } \\
\text { technologies from? }\end{array}$ & $\begin{array}{l}\text { Not at all } \\
\text { useful }\end{array}$ & $\begin{array}{l}\text { Rarely } \\
\text { useful }\end{array}$ & Neutral & Useful & $\begin{array}{l}\text { Very } \\
\text { useful }\end{array}$ \\
\hline 12.5.1 Extension Services & & & & & \\
\hline 12.5.2 Private Firms Rep & & & & & \\
\hline 12.5.3 Distributors & & & & & \\
\hline 12.5.4 NGO & & & & & \\
\hline 12.5.6 Community Meetings & & & & & \\
\hline 12.5.7 Neighbourhood Farmers & & & & & \\
\hline 12.5.8 Others please specify & & & & & \\
\hline
\end{tabular}

Where: $1=$ Not at all useful, $2=$ Rarely useful, $3=$ Neutral, $4=$ Useful, and $5=$ Very useful (Please tick the relevant box)

\begin{tabular}{|l|l|l|l|l|l|}
\hline $\begin{array}{l}\text { 12.6 What do you think about the } \\
\text { following below mentioned factors } \\
\text { for crop protection w.r.t final } \\
\text { harvest? }\end{array}$ & $\begin{array}{c}\text { Not at all } \\
\text { important }\end{array}$ & $\begin{array}{c}\text { Low } \\
\text { importance }\end{array}$ & $\begin{array}{c}\text { Somewhat } \\
\text { important }\end{array}$ & Very important & $\begin{array}{c}\text { Extremely } \\
\text { important }\end{array}$ \\
\hline 12.6.1 Timing of Spraying & & & & & \\
\hline 12.6.2 Instructions for spraying & & & & & \\
\hline 12.6.3 Dosage for spraying & & & & & \\
\hline
\end{tabular}

Where: $1=$ Not at all important, $2=$ Low importance, $3=$ somewhat important, $4=$ Very important, and $5=$ extremely important. (Please tick the relevant box)

\begin{tabular}{|l|l|l|l|l|l|}
\hline $\begin{array}{l}\text { 12.7 How concerned are you about } \\
\text { International Organization for } \\
\text { Standardization (ISO) certification } \\
\text { in crop protection products? }\end{array}$ & $\begin{array}{l}\text { Not at all } \\
\text { concerned }\end{array}$ & $\begin{array}{l}\text { Not really } \\
\text { concerned }\end{array}$ & $\begin{array}{l}\text { Neither } \\
\text { concerned or } \\
\text { Unconcerned }\end{array}$ & Concerned & Very concerned \\
\cline { 5 - 7 } & & & & & \\
\hline
\end{tabular}

Where: $1=$ Not at all concerned, $2=$ Not really concerned, $3=$ neither concerned nor Unconcerned, 4= Concerned, and $5=$ Very concerned. $($ Please tick the relevant box) 
12.8 Would you be willing to adopt High quality crop protection product that would necessitate an initial investment of 10,000(1)-15,000(2)-20,000(3)-25,000(4)-30,000(5)-35,000(6) Rupees (i.e., US\$ 100-150 200-250-300-350) but which would increase your annual harvest by 10 Percent? Before asking the question please first through a dice and the points according to dice upper position will show (e.g., 1-6) afterwards ask the questions? (Please tick the relevant box)

\begin{tabular}{|l|l|}
\hline Yes & \\
\hline No & \\
\hline
\end{tabular}

12.9 If NO: why not:

(a) Do not have enough cash and no easy access to credit:

(b) Do not trust promise to increase harvest by $10 \%$ :

(c) I trust promise of $10 \%$ if from reliable source but other risks are too high (selling price change, drought, other unforeseen problem:

(d) Input provider would have to give cash advance/informal credit:

12.10 How many of yours neighbours are using product A:

Important: please take picture of farmer at their farm or place where interview conducted \& say thanks to farmer for their time and patience to complete this survey. 


\section{DECLARATIONS}

1. I, hereby, declare that this Ph.D. dissertation has not been presented to any other examining body either in its present or a similar form.

Furthermore, I also affirm that I have not applied for a Ph.D. at any other higher school of education.

Göttingen,

(Signature)

(Name in block capitals)

2. I, hereby, solemnly declare that this dissertation was undertaken independently and without any unauthorised aid.

Göttingen,

(Signature)

(Name in block capitals) 